Faculdade de Filosofia, Letras e Ciências Humanas

Programa de Pós-Graduação em Geografia Física

\title{
Estudo microclimático do ambiente de cavernas, Parque Estadual Intervales, SP
}

Bárbara Nazaré Rocha

\begin{abstract}
Dissertação de Mestrado em Geografia Física, do Programa de Pós-graduação da Faculdade de Filosofia, Letras e Ciências Humanas da Universidade de São Paulo.
\end{abstract}

Orientador: Prof. Dr. Emerson Galvani

São Paulo

Junho de 2010 

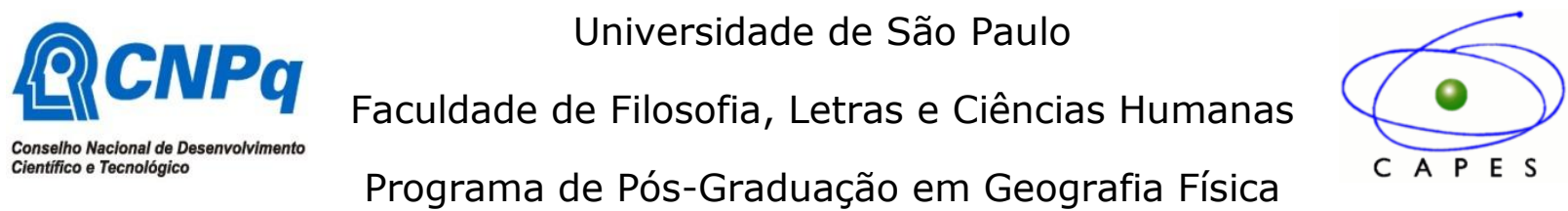

\section{Estudo microclimático do ambiente de cavernas, Parque Estadual Intervales, SP}

Bárbara Nazaré Rocha

São Paulo

Junho de 2010 


\section{Agradecimentos}

Ao CNPQ - Conselho Nacional de Desenvolvimento Científico e Tecnológico - pelo auxílio na compra de equipamentos (processo número 485935/2007-4 do edital Universal MCT/CNPq 15/2007);

À CAPES - Coordenação de Aperfeiçoamento de Pessoal de Nível Superior - pela concessão de bolsa de estudo;

Ao Instituto Florestal/SMA pela autorização do projeto (processo SMA número 260108 - 001.150/ 2008);

Ao meu orientador e amigo, prof. Dr. Emerson Galvani, sempre presente nessa pesquisa;

Ao Rogério, técnico de laboratório, que instalou a estação e esteve sempre a postos quando precisei;

Ao Sr. Eliseu, guia turístico do Parque Estadual Intervales, que cuidou da estação, anotou os visitantes do parque e me acompanhou em todos os trabalhos de campo;

Aos muitos amigos que me acompanharam em campo: Sil, Caio, Gui, Pan, Araça, Francês, Pati e agregados;

A toda minha família e amigos: minha base;

À minha irmã, Mariana, grande companheira de trabalhos de campo, com a qual vivi grandes aventuras;

Aos meus pais, que sempre me apoiaram em tudo.

Muito obrigada! 
Sumário

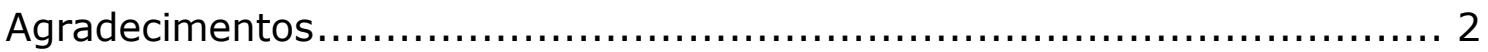

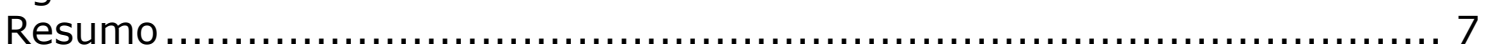

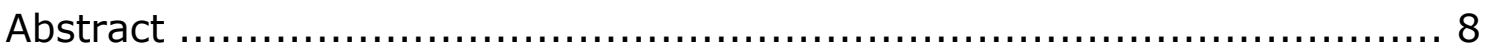

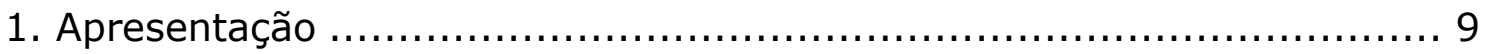

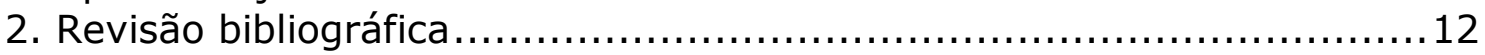

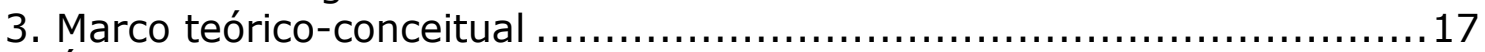

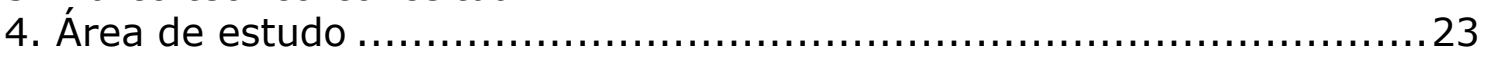

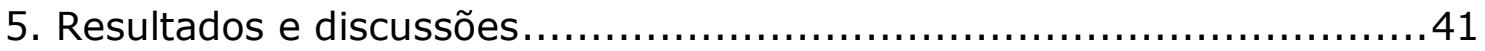

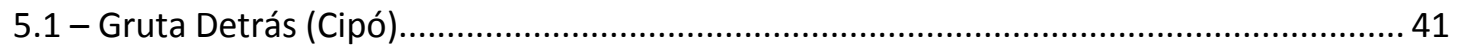

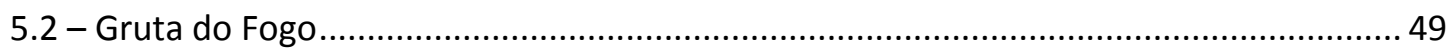

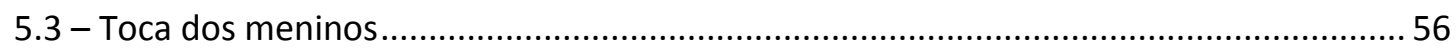

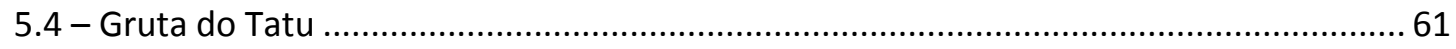

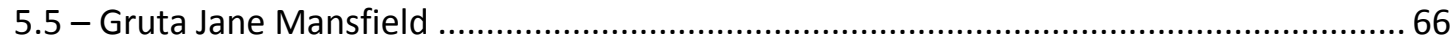

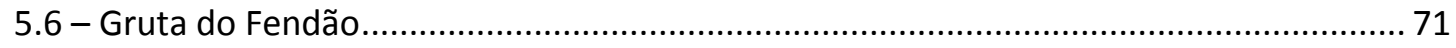

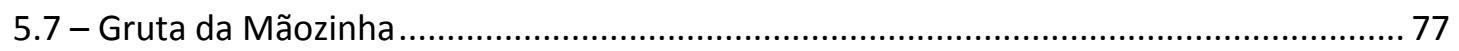

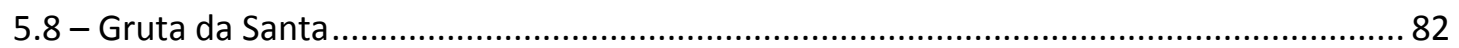

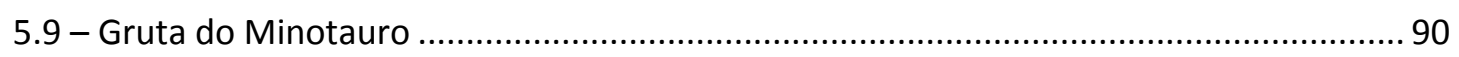

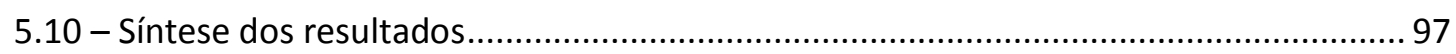

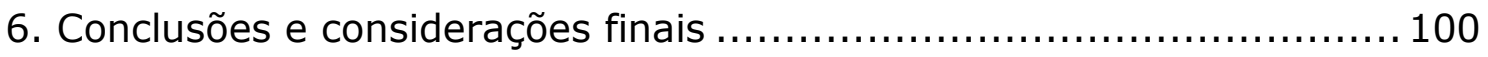

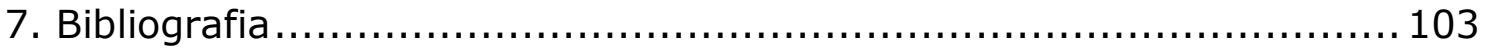

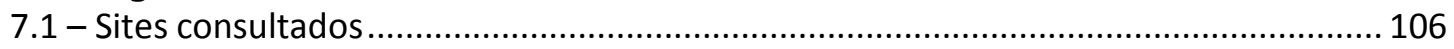

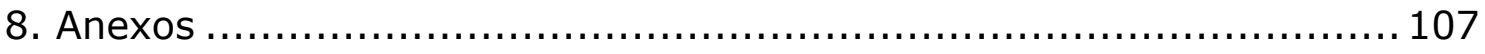

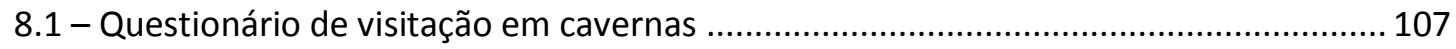




\section{Índice de figuras}

\section{Tabelas}

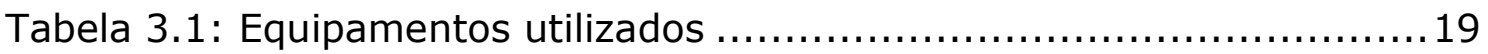

Tabela 4.1: Extensão aproximada das grutas estudadas ....................35

Tabela 5.1.1: Parâmetros estatísticos de temperatura e umidade relativa do

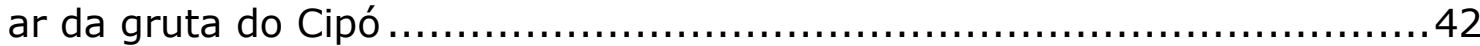
Tabela 5.2.1: Parâmetros estatísticos de temperatura e umidade relativa do

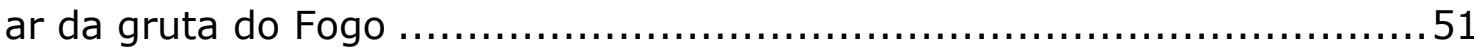
Tabela 5.3.1: Parâmetros estatísticos de temperatura e umidade relativa do ar da gruta dos Meninos ...................................................... 57 Tabela 5.4.1: Parâmetros estatísticos de temperatura e umidade relativa do ar da gruta do Tatu .............................................................. 62 Tabela 5.5.1: Parâmetros estatísticos de temperatura e umidade relativa do ar da gruta Jane Mansfield ....................................................67 Tabela 5.6.1: Parâmetros estatísticos de temperatura e umidade relativa do ar da gruta do Fendão ........................................................... 73 Tabela 5.7.1: Parâmetros estatísticos de temperatura e umidade relativa do ar da gruta da Mãozinha ........................................................ 78 Tabela 5.8.1: Parâmetros estatísticos de temperatura e umidade relativa do

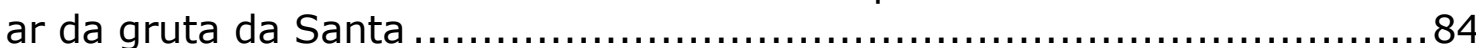
Tabela 5.9.1: Parâmetros estatísticos de temperatura e umidade relativa do

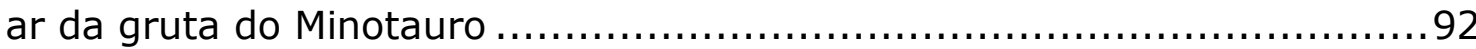
Tabela 5.10.1: Aspectos físicos das cavidades que influenciam em seu microclima

\section{Figuras}

Figura 3.1: Estação meteorológica instalada no P.E.I.......................20

Figura 4.1: Localização do P.E. Intervales. ................................. 23

Figura 4.2: Floresta Ombrófila Densa na trilha da gruta Colorida - PEI...... 30

Figura 4.3: Formação de cavernas calcárias. ................................. 33

Figura 4.4: Localização das cavernas objetos de estudo do Parque Estadual

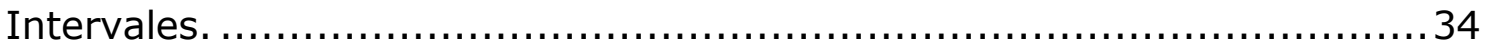

Figura 4.5: Entrada da gruta da Santa. ...................................... 36

Figura 4.6: Estalactites das grutas Detrás e do Minotauro..................... 38

Figura 4.7: Estalagmites da gruta Jane Mansfield............................ 38

Figura 4.8: Cortinas da gruta do Minotauro. .................................. 39

Figura 4.9: Coluna da gruta do Minotauro.................................... 39

Figura 5.1.1: Localização dos termohigrômetros na gruta Detrás............41

Figura 5.1.2: Variação da temperatura do ar na gruta do Cipó. ..............44

Figura 5.1.3: Variação horária da temperatura do ar na gruta do Cipó no dia

7 de fevereiro...................................................................... 45

Figura 5.1.4: Variação da umidade relativa do ar na gruta do Cipó. .........46 
Figura 5.1.5: Variação horária da umidade relativa do ar na gruta do Cipó no dia 7 de fevereiro. ......................................................... 47

Figura 5.1.6: Perfil de gás carbônico atmosférico da gruta do Cipó...........48

Figura 5.2.1: Localização dos termohigrômetros na gruta do Fogo. ..........50

Figura 5.2.2: Variação da temperatura do ar na gruta do Fogo................52 Figura 5.2.3: Variação horária da temperatura do ar na gruta do Fogo no dia 7 de fevereiro. ............................................................ 53

Figura 5.2.4: Variação da umidade relativa do ar na gruta do Fogo..........54

Figura 5.2.5: Perfil de gás carbônico atmosférico da gruta do Fogo..........55

Figura 5.3.1: Localização dos termohigrômetros na gruta dos Meninos.....56

Figura 5.3.2: Variação da temperatura do ar na gruta dos Meninos...........58

Figura 5.3.3: Variação da umidade relativa do ar na gruta dos Meninos....59

Figura 5.3.4: Perfil de gás carbônico atmosférico da gruta dos Meninos....60

Figura 5.4.1: Localização dos termohigrômetros na gruta do Tatu...........61

Figura 5.4.2: Variação da temperatura do ar na gruta do Tatu. ...............63

Figura 5.4.3: Variação da umidade relativa do ar na gruta do Tatu. .........64

Figura 5.4.4: Perfil de gás carbônico atmosférico da gruta do Tatu...........65

Figura 5.5.1: Localização dos termohigrômetros na gruta da Jane Mansfield.

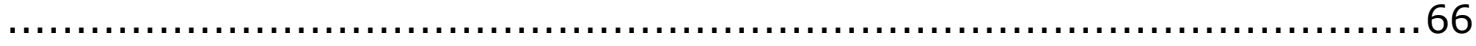

Figura 5.5.2: Variação da temperatura do ar na gruta da Jane Mansfield. .68

Figura 5.5.3: Variação da umidade relativa do ar na gruta da Jane

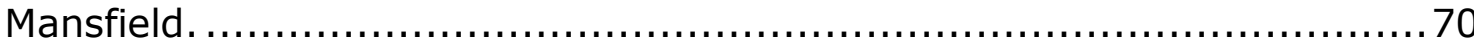

Figura 5.5.4: Perfil de gás carbônico atmosférico da gruta da Jane

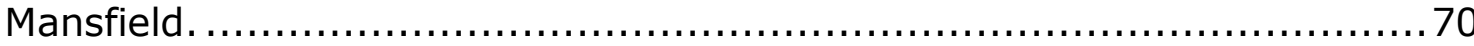

Figura 5.6.1: Localização dos termohigrômetros na gruta do Fendão........72

Figura 5.6.2: Variação da temperatura do ar na gruta do Fendão.............74

Figura 5.6.3: Variação da umidade relativa do ar na gruta do Fendão.......75

Figura 5.6.4: Perfil de gás carbônico atmosférico da gruta do Fendão.......76

Figura 5.7.1: Localização dos termohigrômetros na gruta da Mãozinha.....77

Figura 5.7.2: Variação da temperatura do ar na gruta da Mãozinha..........80

Figura 5.7.3: Variação da umidade relativa do ar na gruta da Mãozinha....81

Figura 5.7.4: Perfil de gás carbônico atmosférico da gruta da Mãozinha....82

Figura 5.8.1: Localização dos termohigrômetros na gruta da Santa.........83

Figura 5.8.2: Variação da temperatura do ar na gruta da Santa................85

Figura 5.8.3: Variação horária da temperatura do ar no dia 14 de fevereiro

na gruta da Santa............................................................. 86

Figura 5.8.4: Variação da umidade relativa do ar na gruta da Santa.........87

Figura 5.8.5: Variação da radiação solar global na estação meteorológica automática instalada no P.E. Intervales. ..................................... 88

Figura 5.8.6: Velocidade do vento na estação meteorológica automática instalada no P.E. Intervales................................................... 88

Figura 5.8.7: Perfil de gás carbônico atmosférico da gruta da Santa.........90

Figura 5.9.1: Localização dos termohigrômetros na gruta do Minotauro....91

Figura 5.9.2: Variação da temperatura do ar na gruta do Minotauro.........93 
Figura 5.9.3: Variação da temperatura do ar nos dias 22 e 23 de fevereiro. ...................................................................................994 Figura 5.9.4: Variação da umidade relativa do ar na gruta do Minotauro.. 95 Figura 5.9.5: Perfil de gás carbônico atmosférico da gruta do Minotauro...96 
A proteção ambiental dos recursos geológicos é uma questão com crescente interesse. A exploração de cavernas é uma das formas de turismo associada a recursos geológicos mais difundida. Por isso, deve-se conhecer suas características ambientais, tais como os climáticas, para definir estratégias de gestão e conservação ambiental associadas a seu uso turístico. Assim, o objetivo geral da pesquisa é detectar as principais alterações microclimáticas ocorridas no ambiente cavernícola em decorrência das visitas turísticas no interior das grutas do PEI, SP. Como objetivos específicos, definiu-se: caracterizar o microclima do ambiente de caverna em condições naturais e elencar características físicas da cavidade que influenciem em seu microclima.

A metodologia consistiu na coleta de dados de temperatura e umidade relativa do ar de nove cavidades com registradores autônomos. Também foram registrados os valores de $\mathrm{CO}_{2}$. A variação dos atributos do clima foi analisada em situação natural e na presença de visitantes.

Os resultados mostram que o microclima das cavernas tende à estabilidade dos valores de temperatura do ar e apresentam umidade relativa do ar e concentração de gás carbônico elevada. Cavernas com rios caudalosos e claraboias não apresentam impacto em sua atmosfera decorrente do turismo, pois as trocas gasosas com o meio externo são facilitadas. Nas grutas secas e afóticas, com entradas e corredores estreitos, o microclima tende à estabilidade, estando mais sujeito a impactos, especialmente elevações na temperatura do ar. O uso de carbureteira também gera acréscimos significativos nas concentrações de gás carbônico.

Palavras-chave: microclima, caverna, impacto ambiental, temperatura do ar, umidade relativa do ar e gás carbônico. 
The ambient protection of the geologic resources is a question with increasing interest. The caves exploration is one of the geological tourism forms more spread out. Therefore, the characteristics of its ambient must be known, such as the climatic ones, to define strategies of management and ambient conservation associates with its tourist use. Thus, the general objective of this research is to detect the main microclimatic alterations in the cave environment in result of the tourist visits in the interior of grottos of PEI, SP. As specific objective, it was purposed to characterize the cave microclimate in natural conditions and to detect the physics characteristics of the caves that influence in its microclimate.

The methodology consisted in collect data of temperature and relative humidity of the air of nine caves with automatic sensors. Also the values of carbonic gas had been registered. The variation of the climatic attributes was analyzed in natural situation and in presence of visitors.

The results show that the caves microclimate tends to have stability values of air temperature and present high values of air relative humidity and carbonic gas concentration. Caves with rivers of great volume and skylights do not present impact in its atmosphere, even in the presence or tourists, because the gaseous exchanges with the external way are facilitated. In dry and dark grottos, with narrow entrances and corridors, the microclimate tends to stability, being subject to impacts, especially rises in the air temperature.

Key words: microclimate, cave, impact, air temperature, air relative humidity, carbonic gas. 


\section{Apresentação}

O interesse por trabalhar com o tema "clima de caverna" na minha dissertação de mestrado, intitulada "Estudo microclimático do ambiente de cavernas, Parque Estadual de Intervales, SP", surgiu na disciplina de Biogeografia, cursada na graduação em geografia pela Universidade de São Paulo. Com a orientação da professora Dra. Sueli Ângelo Furlan, foi realizado um trabalho de campo para o Parque Estadual Intervales (PEI), onde meu grupo de trabalho coletou dados de temperatura e umidade relativa do ar de uma das cavernas do parque: a gruta Colorida. Os resultados inéditos foram apresentados no Congresso Brasileiro de Espeleologia e apontaram para a necessidade de maiores estudos sobre o clima desse ambiente tão peculiar. Este trabalho provou que há alterações nos atributos do microclima da gruta Colorida, como o aumento da temperatura do ar, na presença de visitantes.

Após esse trabalho, o convite para coordenar a equipe de climatologia dos Planos de Manejo Espeleológicos do Estado de São Paulo consolidou o meu interesse pelo tema. As pesquisas feitas para os PMEs enriqueceram os resultados obtidos nessa dissertação.

"O ambiente cavernícola stricto sensu é considerado um dos mais peculiares e estáveis existentes na biosfera. A capa rochosa que cobre e resguarda as cavernas das variações climáticas bruscas que ocorrem na superfície dá a esse ambiente uma série de características próprias, que condicionam a diversidade de vida animal e vegetal que se desenvolve em seu interior" (LINO, 2001, p. 203). Deste modo, as cavernas formam um ambiente único, com entrada de nutrientes dificultada e ausência total de luz nas zonas mais profundas, apresentando um microclima específico e ainda pouquíssimo estudado.

O estudo deste microclima é importante para compreender os fatores limitantes ao desenvolvimento e distribuição espacial da vida no ambiente cavernícola, o desenvolvimento dos espeleotemas e as alterações causadas pelo turismo. Também pode ajudar no entendimento dos processos de formação das cavernas e das mudanças climáticas globais, através de um estudo combinado com análises mineralógicas dos espeleotemas. 
As visitas às unidades de conservação, em especial aos parques estaduais, tornaram-se uma atividade altamente disseminada nas últimas décadas, ocasionando a intensificação das visitas aos ambientes naturais protegidos. Grande parte desse fenômeno pode ser atribuída à disseminação do ecoturismo que pode vir a causar impactos negativos sobre o meio ambiente (SANO, 2007).

A exploração de cavernas é uma das formas de turismo associada a recursos geológicos mais difundida. Por isso, deve-se conhecer suas características ambientais para definir estratégias de gestão e conservação ambiental associadas a seu uso turístico.

Devido a suas características físicas, as cavernas são ambientes únicos, com entrada de nutrientes dificultada e ausência total de luz nas zonas mais profundas, apresentando um microclima específico.

A iluminação e a presença de visitantes, dentre outras variáveis, modificam as condições ambientais das cavidades o que leva a uma degradação progressiva, favorecendo, inclusive, a destruição de espeleotemas. Estas variações ambientais correspondem a alterações na temperatura e umidade relativa do ar, na taxa de gás carbônico e na proliferação de algas.

Tendo em vista a importância do tema, o objetivo geral desta pesquisa é detectar as principais alterações microclimáticas ocorridas no ambiente cavernícola em decorrência das visitas turísticas para subsidiar as ações de manejo no interior das grutas do Parque Estadual de Intervales, SP. Como objetivos específicos, definiu-se: 1) caracterizar o microclima do ambiente de caverna em condições naturais e 2) elencar características físicas da cavidade que influenciem em seu microclima.

Para isso, o estudo deve registrar inicialmente as condições ambientais naturais da caverna, o que permitirá detectar a perturbação ambiental que grupos humanos produzem no interior desta. Assim, deve-se analisar as variações espaciais e temporais dos atributos em função do número de visitantes e tempo de permanência nas cavernas, da capacidade de ventilação natural da gruta, do grau de gotejamento e das dimensões e formas dos salões. 
Para atingir os objetivos propostos, algumas hipóteses nortearam o desenvolvimento do trabalho.

- O microclima de cavernas, em situação natural, deve apresentar atrasos na assimilação das condições atmosféricas externas, não variando seus atributos nas zonas afóticas;

- A visitação turística, pelo uso de iluminação artificial e pelo calor do corpo humano, poderá alterar a temperatura do ar do ambiente de caverna que, por consequência, modifica a umidade relativa do ar;

- O turismo em caverna altera a concentração de gás carbônico na atmosfera do ambiente de caverna, em decorrência da iluminação com uso de carbureto.

O presente trabalho está estruturado com os seguintes capítulos: 1Apresentação, onde se aponta os objetivos, hipóteses e justificativa do trabalho; 2- Revisão de Literatura, abrangendo citações e resumos das principais obras consultadas; 3- Marco teórico-conceitual, com as teorias norteadoras do trabalho e procedimentos de pesquisa; 4- Área de estudo, onde se caracteriza o Parque Estadual Intervales e as cavernas pesquisadas; 5- Resultados e discussão, com os resultados e análise dos dados; 6- Conclusões e considerações finais, com as conclusões e apontamentos sobre o trabalho, 7- Bibliografia, onde são apresentadas as obras consultadas e 8- Anexos.

Cabe ressaltar que a elaboração deste trabalho foi possível graças ao auxilio financeiro concedido pelo CNPQ - Conselho Nacional de Desenvolvimento Científico e Tecnológico -, para compra de equipamentos (processo número 485935/2007-4 do edital Universal MCT/CNPq 15/2007), e pela CAPES - Coordenação de Aperfeiçoamento de Pessoal de Nível Superior -, com a concessão de bolsa de estudos. A pesquisa em área de parque foi autorizada pelo Instituto Florestal (processo SMA número 260108 $-001.150 / 2008)$. 


\section{Revisão bibliográfica}

Entende-se por cavidade natural subterrânea "todo e qualquer espaço subterrâneo penetrável pelo ser humano, com ou sem abertura identificada, (...) incluindo seu ambiente, seu conteúdo mineral e hídrico, as comunidades bióticas ali encontradas e o corpo rochoso onde se inserem, desde que a sua formação tenha sido por processos naturais, independentemente de suas dimensões ou do tipo de rocha encaixante" (BRASIL, 2004). Resumidamente, entenderemos neste trabalho que "cavernas são cavidades naturais com dimensões que permitem acesso ao ser humano" (Karmann, 2003).

O microclima do ambiente de cavernas ainda é pouco conhecido. Estudos sobre esta temática envolvem, na maioria dos casos, uma análise de somente dois atributos: a temperatura e a umidade relativa do ar.

Por microclima entende-se que este abrange a camada de ar próxima à superfície.

"A camada de ar inferior à altura convencionada de cerca de $2 \mathrm{~m}$, vamos chamar de camada de ar junto ao solo. (...) Quanto mais nos aproximamos da superfície do solo, tanto maior é o atrito e por isso tanto menor é a velocidade do vento e, consequentemente, também a mistura do ar que permitiria compensar a diferença em pequenos espaços" (GEIGER, 1990).

Carvalho (2004) realizou um estudo de microclima subterrâneo na Gruta Olhos D'água, em Castro, PR. Neste trabalho foram realizadas medições de temperatura e umidade relativa do ar com uso de conjuntos psicrométricos, o que inviabiliza a deteç̧ão de eventuais influências da presença humana no ambiente de cavernas, pois as medidas só podem ser realizadas na presença do pesquisador.

Um estudo microclimático da Gruta Ubajara, $\mathrm{CE}$, demonstrou que a temperatura e a umidade relativa do ar na entrada da caverna apresentam maiores variações do que em seu interior, sendo as flutuações maiores no período seco, comparado ao chuvoso (VERÍSSIMO et al, 2003). Neste trabalho também se evidenciou que os spots de iluminação contribuem para a elevação da temperatura do ar dos salões menores da caverna. Por esse 
motivo, em muitas cavernas, já há substituição dos spots por lâmpadas frias.

Longhitano et al (2006) e Rocha et al (2006) realizaram uma caracterização preliminar do microclima do ambiente de cavernas, através de um estudo de caso na Gruta Colorida do Parque Estadual de Intervales, SP. Nestes estudos foram utilizados cinco registradores de temperatura e umidade relativa do ar alocados ao longo da galeria superior da gruta (transeção da entrada até o final do corredor), durante período de dois dias. Percebeu-se um atraso na assimilação das mudanças do tempo exterior à medida que se adentra no interior da gruta. Também foi detectada uma variação da temperatura do ar no interior da gruta em função da presença humana.

O aumento da temperatura do ar decorrente da visitação turística foi apontado também nos trabalhos de Viana Júnior (2002) e Sánchez-Martos et al (2002). No primeiro, as alterações de mais de $2^{\circ} \mathrm{C}$ foram registradas na caverna Santana do Parque Estadual Turístico do Alto Ribeira (PETAR), SP, na presença de três visitantes, sem uso de carbureteira. O segundo estudo foi realizado na caverna Cueva del Água de Iznalloz, em Granda, Espanha. Sánchez-Martos et al (op. cit.) concluíram que a magnitude das alterações na temperatura do ar está diretamente relacionada com o número de visitantes e seu tempo de permanência na gruta e que a cavidade recupera-se termicamente poucas horas após a visita.

Scaleante (2003) concluiu que o uso de carbureteiras é o principal fator responsável pela elevação da temperatura do ar em ambientes cavernícolas. Em sua dissertação, ele observou que a passagem de 310 visitantes pelo Salão do Encontro, na caverna Santana, SP, não provocou aumento na temperatura do ar, enquanto sete visitantes com carbureteira causaram o aumento de $4,5^{\circ} \mathrm{C}$. Além disso, quando o ambiente é impactado pela presença de visitantes usando iluminação a carbureto, a caverna demora mais tempo para se recuperar termicamente.

Segundo estudos efetuados no salão das pinturas da caverna Altamira, na Espanha, o calor dissipado pelo corpo humano varia de $82 \mathrm{~W}$ a 116W (VILLAR et al, 1984 apud SCALEANTE, 2003). 
Sano (2007) aponta que "as cavernas são ambientes sensíveis à presença de visitantes em seu interior, pois há a alteração da temperatura, com o calor emitido pelo corpo humano, da umidade e da composição do ar por conta da respiração humana e do gás emitido pelas carbureteiras, que grudam nos espeleotemas e tiram a beleza natural com seu resíduo negro. Além disso, o número excessivo de pessoas caminhando no interior das grutas causa impactos no solo, que fica compactado, e, em alguns casos, podem deixar lixo, como resto de alimentos e garrafas".

Também, "a simples presença humana em ambientes cavernícolas, desde que em quantidade superior àquela que o sistema é capaz de absorver, provoca impactos irreversíveis sobre a biota, o maciço rochoso e as formações internas" (SCALEANTE, 2003).

De acordo com a Resolução CONAMA no 001 (BRASIL, 1986), entende-se por impacto ambiental "qualquer alteração das propriedades físicas, químicas e biológicas do meio ambiente, causada por qualquer forma de matéria ou energia resultante das atividades humanas que, direta ou indiretamente, afetam: a saúde, a segurança e o bem-estar da população; as atividades sociais e econômicas; a biota; as condições estéticas e sanitárias do meio ambiente; a qualidade dos recursos ambientais". Seguindo a mesma linha, Moreira define impacto ambiental como "qualquer alteração no meio ambiente em um ou mais de seus componentes - provocada por uma ação humana" (1992, p 113). Ou ainda "a mudança em um parâmetro ambiental, num determinado período e numa determinada área, que resulta de uma dada atividade, comparada com a situação que ocorreria se essa atividade não tivesse sido iniciada" (WATHERN, 1988, p.7 apud SÁNCHEZ, 2008). O impacto também se refere à capacidade do meio em absorvê-lo.

Assim, os impactos podem ter caráter positivo ou negativo, ser reversíveis ou permanentes. Já a degradação da qualidade ambiental, refere-se somente às alterações negativas, sendo definida como "a alteração adversa das características do meio ambiente" (BRASIL, 1981).

Os impactos ambientais resultam de um aspecto ambiental, que é o "mecanismo através do qual uma ação humana causa um impacto ambiental. Uma mesma ação pode levar a vários aspectos ambientais e, por 
conseguinte, causar diversos impactos ambientais. Da mesma forma, um determinado impacto ambiental pode ter várias causas" (MOREIRA, 1992, p. 33 apud SÁNCHEZ, 2008).

Atividades humanas -> aspectos ambientais -> impactos ambientais

\section{Na caverna:}

Visitação turística -> aumento da energia disponível -> elevação da temperatura do ar

Os impactos ambientais podem ser irrelevantes ou significativos. "Significativo é tudo aquilo que tem significado; é sinônimo de expressivo. Mas é com o sentido de considerável, suficientemente grande, ou ainda como importante que deve ser entendida a locução impacto ambiental significativo. A definição, porém, não resolve o problema porque impacto significativo é um termo carregado de subjetividade. E dificilmente poderia ser de outra forma, uma vez que a importância atribuída pelas pessoas às alterações ambientais chamadas impactos depende de seus entendimentos, de seus valores, de sua percepção" (MOREIRA, 1992, p.111 apud SÁNCHEZ, 2008). Por esse motivo, é comum se fazer correlações matemáticas com atribuição de pesos para as variáveis analisadas. No presente trabalho, considera-se significativo o impacto que supera as amplitudes encontradas em situação natural.

O turismo no ambiente de cavernas não traz impactos somente no regime de temperatura. O microclima de caverna é bastante estável (LINO, 2001). Portanto, pequenas alterações climáticas podem causar grandes mudanças no ambiente cavernícola. O turismo, ao alargar corredores, altera a circulação; a iluminação eleva a temperatura do ar e permite o crescimento de algas e consequente aumento na taxa de gás carbônico; a respiração humana também ajuda a criar um ambiente de estufa. 0 aumento do $\mathrm{CO}_{2}$ pode afetar o equilíbrio químico dos espeleotemas. $\mathrm{O}$ aumento de $1^{\circ} \mathrm{C}$ na temperatura resulta num aumento de oito vezes na capacidade de concentração de vapor d'água, diminuindo a umidade relativa do ar e aumentando a concentração de gás carbônico, naquele instante para aquela temperatura (GILLIESON, 1996). 
O aumento na concentração de gás carbônico no ambiente cavernícola, em decorrência da presença humana, foi detectado no estudo de Liñan et al (2006). A taxa de $\mathrm{CO}_{2}$ no interior de uma cavidade é condicionada pela capacidade de ventilação natural da gruta. A ventilação ocorre em função da diferença de temperatura entre os meios externo e interno. Logo, se há um aumento na temperatura interna da caverna em decorrência da presença humana, haverá variações na circulação e, consequentemente, nas taxas de gás carbônico. Além disso, $\mathrm{O} \mathrm{CO}_{2}$ é expirado pelos seres humanos no processo respiratório.

Palomba (1995), após estudar a gruta Pozzi della Piana, na Itália, concluiu que vários são os fatores que contribuem para o aumento da concentração de gás carbônico no interior da caverna. Os fatores podem se relacionar à fisiologia da gruta, tais como a produção de organismos oxidantes a partir do material orgânico presente no substrato e a respiração da fauna, ou originários da visitação turística, como a combustão do acetileno produzido pelas carbureteiras e a respiração dos visitantes. 


\section{Marco teórico-conceitual}

Adotou-se, como base teórica desta pesquisa, a teoria geossistêmica. Esta é bastante difundida em estudos geográficos e se adequa a este estudo, pois, segundo Sotchawa (1977):

- Mostra-se pertinente e adequada à organização sistemática e a busca de síntese;

- Preocupa-se com a relação entre variáveis dinâmicas e gênese;

- Permite lidar com os princípios de interdisciplinaridade, síntese, abordagem multiescalar e dinâmica;

- Promove o reconhecimento de unidades espaciais com características elementares, relacionais e dinâmicas, semelhantes entre si, mesmo incluindo-se o antrópico;

- Possibilita a discriminação de unidades operacionais de planejamento;

- Os sistemas podem ser definidos como conjuntos de elementos com variáveis e características diversas, que mantém relações entre si e entre o meio ambiente.

Esta teoria considera a natureza enquanto um sistema dinâmico aberto e hierarquicamente organizado, passível de delimitação ou de ser circunscrito espacialmente em sua tridimensionalidade (RODRIGUES, 2001: 73). Geossistemas representam a organização espacial resultante da interação dos componentes físicos da natureza (sistemas), aí incluídos clima, topografia, rochas, águas, vegetação e solos, dentre outros, podendo ou não estarem todos esses componentes presentes.

Os geossistemas são duais, permitindo, por um lado, analisar a estrutura homogênea, que caracteriza o geômero, e, de outro, as qualidades integrativas dos geossistemas, que caracteriza o geócoro. Como geômero entende-se que é a estrutura homogênea dos geossistemas, enquanto que os geócoros são as estruturas heterogêneas, que permitem, porém uma análise integrada para melhor compreensão da dinâmica dos sistemas (SOTCHAWA, 1977). 
A dinâmica classifica os geossistemas de acordo com seus estados sucessivos, podendo assumir ou propor hipóteses sobre sua dinâmica futura, característica fundamental para aplicação e planejamento. Assim, o caráter preditivo de tal teoria é uma das principais aplicabilidades.

Com base nesta teoria, dados podem ser sistematizados, a partir de modelagem com mensuração das trocas, circuitos e balanços de matéria e energia nos sistemas e subsistemas.

Outrossim, o entendimento do objeto de estudo enquanto um geossistema permite uma avaliação ambiental deste, pois as cavernas são sistemas de estruturas duais, com fluxo de matéria e energia, e passíveis de espacialização.

Esta pesquisa tem como base metodológica o raciocínio analítico, visto que este relaciona fatos (partes) para explicar o contexto (todo). Dentre os diferentes tipos de análise, optou-se pela hipotético-dedutiva, com formulação de hipóteses enquanto respostas provisórias, sendo estas as variáveis analíticas do trabalho. O raciocínio também se organizou por uma base empírica, por meio de análises experimentais controladas.

O procedimento técnico para o estudo deu-se na forma de coletas sistemáticas de dados, através de trabalho de campo.

As cavernas pesquisadas foram: Fendão, Mãozinha, Minotauro, Jane Mansfield e Santa, do agrupamento Bocaina/ Lageado (PEI) e Fogo, Meninos, Detrás e Tatu, do núcleo Sede. A escolha das cavernas seguiu a proposta dos Planos de Manejo Espeleológico que considera essas cavernas como as de maior visitação no parque. Portanto, são objeto de plano de uso público e uma exigência de interdição.

A elaboração de trabalhos de campo permitiu a instalação e retirada dos sensores registradores de temperatura e umidade relativa do ar e a coleta dos dados referentes à concentração de gás carbônico. Nesta etapa, foram instalados três termohigrômetros em cada cavidade, sendo um na entrada (caracterização de microclima transicional), outro em um salão dentro do circuito tradicional de visitação e o terceiro em um trecho sem visitação, porém periférico a uma área visitável. Os equipamentos utilizados no monitoramento da caverna apresentavam sensibilidade e precisão suficientes para registrar pequenas variações. Cabe ressaltar que o uso de 
tais instrumentos somente foi possível com o apoio do Conselho Nacional de Desenvolvimento Científico e Tecnológico (CNPQ).

A tabela abaixo (tabela 3.1) apresenta os equipamentos utilizados em cada um dos agrupamentos estudados e suas características.

Tabela 3.1: Equipamentos utilizados

\begin{tabular}{|c|c|c|c|c|}
\hline Instrumento & Marca & Modelo & Precisão & Acurácia \\
\hline termohigrômetros & Onset & Stow Away & 0,1 & $\begin{array}{c}0,22^{\circ} \mathrm{C}(\mathrm{T}) \mathrm{e} \\
2,5 \%(\mathrm{UR})\end{array}$ \\
\hline $\begin{array}{c}\text { Sensor de gás } \\
\text { carbônico }\end{array}$ & Tracom & TEL-7001 & 0,1 & $50 \mathrm{ppm}$ \\
\hline
\end{tabular}

Organização: Bárbara N. Rocha, 2010.

O monitoramento de cada caverna foi realizado durante período de uma semana (sete dias) com resolução temporal dos termohigrômetros de seis minutos. O objetivo foi mostrar as variações naturais dos atributos do clima (períodos com ausência de visitação - situação controle), e o impacto da visitação. Para o segundo caso, foram realizadas visitas simuladas com grupos que reproduzissem o número, o tempo de permanência e o comportamento dos visitantes tradicionais. Os trabalhos de campo para instalação e retirada dos aparelhos ocorreram entre os meses de fevereiro e abril de 2009.

A atividade de visitação na caverna foi realizado por meio de um questionário (anexo 8.1), onde constavam: data e horário de entrada e de saída dos visitantes, quantidade de visitantes e quantidade de carbureteiras e de lanternas utilizadas pelos turistas.

Os dados de gás carbônico foram colhidos em vários pontos de cada caverna (mínimo de dez amostras), englobando todo o circuito tradicional de visitação.

Após a coleta dos dados, foram confeccionados perfis térmicos, higrométricos e de dióxido de carbono $\left(\mathrm{CO}_{2}\right)$ de cada cavidade. O trabalho com perfis facilita a visualização das alterações dos parâmetros analisados, permitindo estabelecer correlações entre as mudanças de cada parâmetro e a presença de visitantes. 
Além dos perfis, a temperatura e umidade relativa do ar também foram analisadas a partir de parâmetros estatísticos (média, máximo, mínimo, amplitude, moda, variância e desvio padrão), com destaque para as amplitudes registradas nos períodos com visitação. O estudo da moda, valor que surge com mais frequência nas amostras, é importante neste trabalho, pois mostra o valor de temperatura e umidade que se espera encontrar nas cavernas em que há estabilidade microclimática. A mediana também ajuda a detectar climas estáveis, pois, quando a distribuição dos dados é simétrica, a média e a mediana coincidem.

A partir dos dados de gás carbônico, foram gerados gráficos de linha, mostrando a variação do parâmetro da entrada da caverna até o seu término.

No ambiente externo, próximo na sede do Parque Estadual Intervales, foi instalada uma estação meteorológica automática composta por sensores registradores de temperatura do ar, umidade relativa do ar, direção e velocidade do vento, chuva e radiação solar. O uso desses equipamentos justifica-se para controle climático do ambiente externo e comparação com os dados obtidos no interior da gruta (figura 3.1).

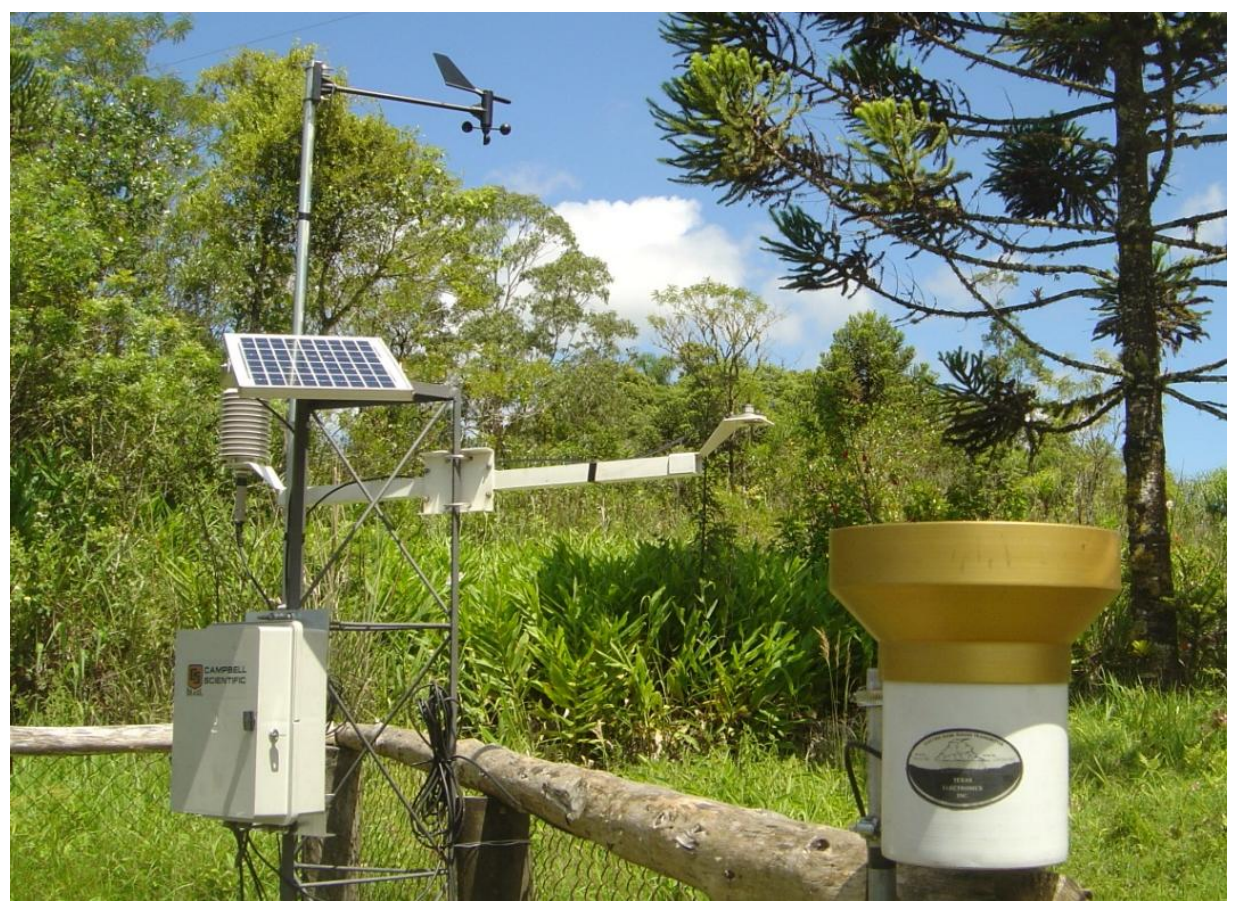

Figura 3.1: Estação meteorológica instalada no P.E.I.

Por Bárbara N. Rocha, 2009. 
Todos os dados obtidos foram calibrados para serem utilizados. Antes de serem instalados nas cavernas, os registradores de temperatura e umidade ficavam juntos, sob as mesmas condições climáticas, para posterior comparação e calibração. Já a estação ficou instalada por mais de um mês junto a outra, do departamento de Geografia da USP, apresentando dados bastante fiéis.

Por fim, os parâmetros levantados foram analisados, buscando-se a compreensão da dinâmica natural do microclima de cavernas e dos impactos da visitação na atmosfera cavernícola, que podem subsidiar e/ou apontar diretrizes para estabelecimento da capacidade de carga de cada caverna e o zoneamento ambiental.

Cabe ressaltar, no entanto, que a metodologia para este estudo apresenta algumas limitações, pois o período de monitoramento climático não permite compreender as alterações sazonais naturais do clima do ambiente de cavernas.

Para melhor compreensão dos resultados, além de permitir a caracterização da área e do tema, foram utilizadas fontes bibliográficas no âmbito da climatologia geográfica, espeleologia, geologia de terrenos cársticos, geomorfologia cárstica e biogeografia. As fontes cartográficas incluíam mapas temáticos do Parque Estadual de Intervales e a planta das cavernas estudadas.

As técnicas adotadas neste trabalho seguiram a seguinte sequência:

1) Pesquisa bibliográfica e cartográfica: o levantamento bibliográfico permitiu a formação de uma base teórico-metodológica e compreensão da dinâmica microclimática do ambiente cavernícola, enquanto o levantamento cartográfico ajudou na caracterização da área estudada.

2) Preparo do trabalho de campo: ajudou na escolha das grutas estudadas e em sua caracterização.

3) Levantamento dos dados de campo: permitiu a instalação e retirada dos registradores de temperatura e umidade e anotação dos dados de gás carbônico atmosférico.

4) Análises dos dados de campo: análise e tratamento dos dados obtidos em campo para confecção de gráficos e análises estatísticas e correlatórias. 
5) Redação do trabalho final: apresentação da evolução do trabalho e os resultados obtidos. 


\section{4. Área de estudo}

O Parque Estadual Intervales (PEI) localiza-se na região sul do Estado de São Paulo, há 270 km da capital. Encontra-se inserido nos municípios de Guapiara, Ribeirão Grande, Sete Barras, Eldorado e Iporanga, no divisor de águas das bacias do Paranapanema e Ribeira de Iguape. Abrange a antiga fazenda do Banco do Estado de São Paulo - BANESPA, adquirida pela Fundação Florestal - SMA, com área total de 41.705 hectares (SÃO PAULO, 2009).

Figura 4.1: Localização do P. E. Intervales.

Fonte: SÃO PAULO, 2009. 


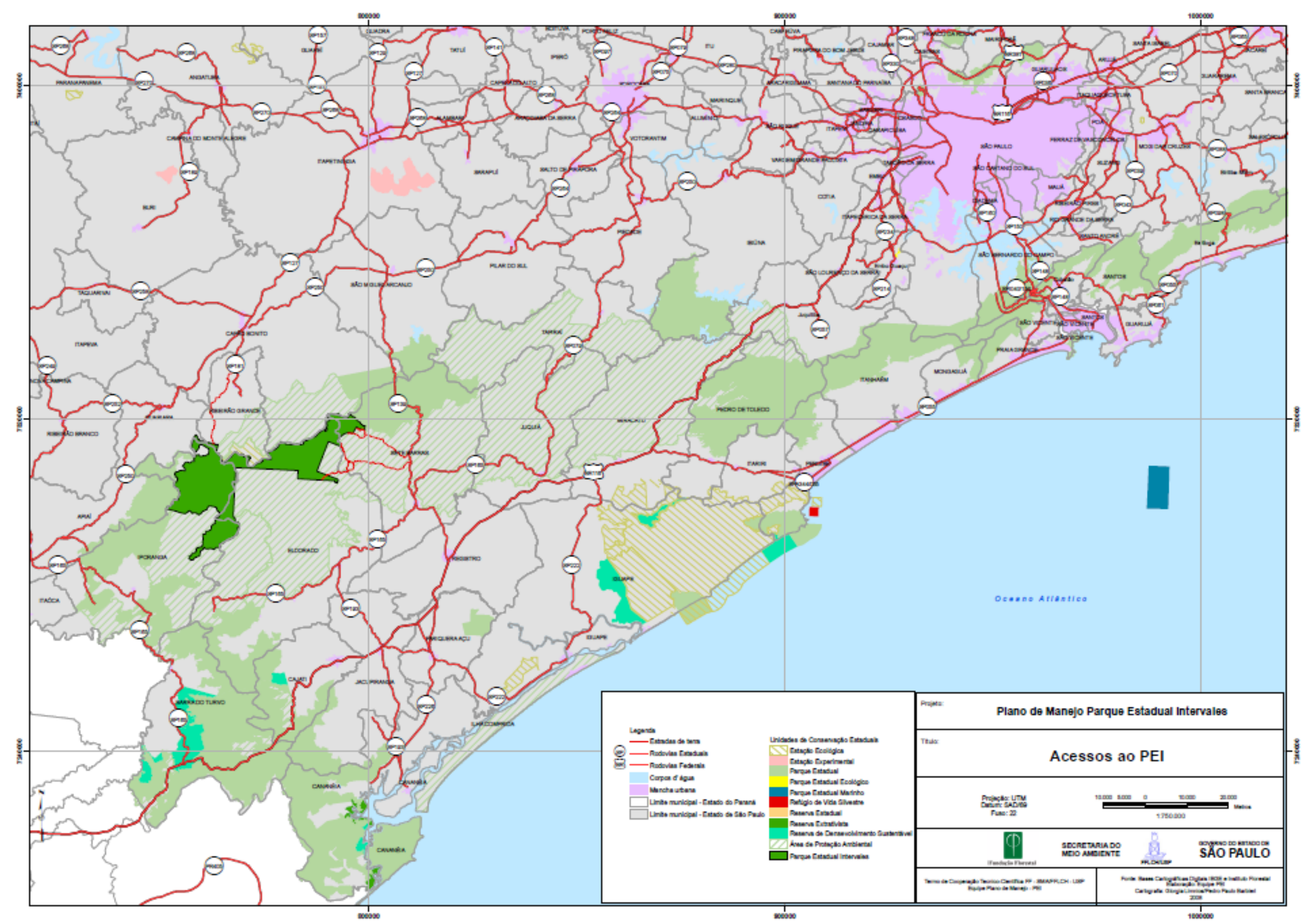


A história do parque se inicia na segunda metade do século $X X$, quando a Companhia do Incremento Rural do Altiplano Paulista instalou-se na serra de Paranapiacaba, para implantar um projeto agropecuário que não foi bem sucedido, perdendo suas terras para o antigo Banco do Estado de São Paulo. Na década de 1970, o BANESPA, visando o aproveitamento econômico da área, realizou obras de infraestrutura, tais como a construção de estradas, de uma pequena vila com saneamento básico (o espaço da atual Sede) e de bases de vigilância. Na região da Sede, foi instalada uma fábrica de beneficiamento de palmito, em cujas instalações funcionam, atualmente, oficinas mecânica e de carpintaria e um almoxarifado.

Na década de 1980, com a decretação da Área de Proteção Ambiental da Serra do Mar, a fazenda Intervales foi a ela incorporada, passando para a administração da Fundação Florestal no ano de 1987. Em 1995, nascia juridicamente o Parque Estadual Intervales (decreto no 40.135, de 08/06/1985).

O termo parque estadual pode ser entendido como "espaço territorial terrestre e/ ou aquático para proteção ambiental, dotado de atributos naturais ambientalmente relevantes a serem preservados em caráter permanente. Seu objetivo básico é a conservação in situ da biodiversidade, de sua dinâmica funcional e dos processos ecológicos fundamentais, bem como dos seus atributos paisagísticos, culturais e histórico, destinando-se a fins científicos, educativos, recreativos e ecoturísticos, de acordo com as diretrizes de seu plano de manejo, resguardando a área de quaisquer alterações que os desvirtuem para garantir a preservação de seus ecossistemas" (Parque Estadual Intervales: plano de gestão ambiental fase 1 , p. 09).

Segundo o decreto no 40.135, de 08/06/1995, que cria o Parque Estadual de Intervales, a área destina-se a proteção aos mananciais, aos sítios espeleológicos e às encostas da Serra do Mar/ Paranapiacaba, cobertas pela Mata Atlântica. Este domínio recebeu da UNESCO o título de Reserva da Biosfera e constitui abrigo de dezenas de espécies ameaçadas de extinção, que somente conseguem sobreviver em territórios florestados de grande extensão (SÃO PAULO, 1995). 
Segundo Ross e Moroz (1997), o PEI está inserido, geomorfologicamente, na unidade Escarpa/ Serra do Mar e Morros Litorâneos que consiste em uma faixa de encostas com vertentes abruptas que margeiam o planalto Atlântico desde a região do planalto da Bocaina, na divisa com o Estado do Rio de Janeiro, até a região do Vale do Ribeira de Iguape. Predominam formas de relevo denudacionais, cujo modelado constitui-se basicamente em escarpas e cristas com topos aguçados e topos convexos, com entalhamento dos vales variando entre 80 a mais de 160 metros e dimensão interfluvial entre menos de 250 até 3750 metros. As altitudes variam de 20 a 1000 metros e as declividades predominantes são superiores a 40\%. A litologia dessa unidade morfológica é basicamente constituída por gnaisses, migmatitos, micaxistos e granitos.

Nesta unidade de relevo bastante dissecado, a drenagem apresenta padrão dendrítico, adaptado às direções das estruturas que estão relacionadas com falhas, fraturas e contatos litológicos. Por ser uma unidade com formas de dissecação muito intensas, com vales de grande entalhamento, com alta densidade de drenagem e vertentes muito inclinadas, esta área apresenta um nível de fragilidade potencial muito alto, estando sujeita a processos erosivos pluvio-fluviais agressivos e movimentos de massa espontâneos e induzidos (ROSS, MOROZ, 1997).

A Geologia regional do Parque Estadual Intervales é composta por três grandes conjuntos de unidades rochosas: unidades relacionadas ao embasamento cristalino, unidades de rochas metassedimentares (incluindo as rochas carbonáticas) e os granitóides intrusivos (ROSS, MOROZ, op. cit.). Na área do Parque Estadual de Intervales predominam rochas metassedimentares de composições diversas. Os metassedimentos representam uma sequência deposicional relacionada a um ambiente marinho de águas profundas, passando para sedimentos marinhos mais rasos, desde a plataforma oceânica até a continental.

Por situar-se em uma área serrana, o relevo do P. E. Intervales é fortemente dissecado, fazendo uma transição entre os terrenos elevados do Planalto Guapira e as baixadas do Vale do Ribeira, com altitudes que variam entre 1095 e 60 metros. 
As partes norte e nordeste do parque formam um importante divisor de águas de duas grandes bacias hidrográficas, a do rio Ribeira de Iguape e a do rio Paranapanema. A maioria dos rios do parque drena em direção ao Ribeira, exceto a porção a noroeste que segue para o Paranapanema. Nos setores de serras e escarpas os rios apresentam vales encaixados e profundos, bem como trechos encachoeirados.

A maior parte do frontão escarpado da serra de Paranapiacaba tem constituição granítica, enquanto as cristas salientes costumam ser quartzíticas e os relevos mais elevados são sustentados por calcários. Os filitos e xistos configuram relevos baixos e abrigam os principais rios subsequentes.

Conforme a compartimentação geomorfológica adotada por Ross e Moroz (1997), a maior parte da área do parque insere-se na unidade morfoescultural do Planalto Atlântico e uma pequena área na Depressão do Baixo Ribeira. O planalto Atlântico é parte constituinte do Cinturão Orogênico do Atlântico com relevo elevado e muito dissecado, sustentado predominantemente por rochas cristalinas de idade pré-cambriana.

O relevo do parque pode ser dividido em três compartimentos principais: o planalto de Guapira, o planalto do Ribeira Turvo e a depressão do Baixo Ribeira. O primeiro compartimento situa-se na região norte, com altitudes predominantes entre 800 e 1000 metros, representando a porção mais elevada do parque. O planalto do Ribeira Turvo ocorre em quase toda extensão de Intervales, sendo que as altitudes giram em torno de 200 e 800 metros. Por fim, a porção sudeste abriga a depressão do Baixo Ribeira, com altitudes variando de 60 a 190 metros.

Os principais tipos de solos presentes no Parque são: Neossolo Litólico, Neossolo Fúlvico, Cambissolo Háplico, Latossolo Vermelho-Amarelo, Latossolo Bruno-Amarelado e Organossolo associado a gleissolo. Há uma predominância de Neossolos Litólicos e Cambissolos Háplicos associados a granito, filito ou calcário. Em seguida têm-se Latossolos Vermelho-Amarelos associados a granito e Latossolos Bruno-Amarelados associados a filito, ambos de textura argilosa e com associação a Argissolo Vermelho-Amarelo. Os Neossolos Fúlvicos apresentam associação com filito, calcário, mármore, diabásio e siltito, micaxisto e material aluvial. Em menor ocorrência está os 
Organossolos e Gleissolos associados a micaxisto e material aluvial (SÃO PAULO, 2009).

O clima predominante da região é o subtropical de altitude (Cwb), segundo a classificação climática de Köppen, com alta pluviosidade no verão, sem inverno seco, com chuvas se estendendo por todo o ano.

A feição climática da região do Vale do Rio Ribeira de Iguape é classificada, segundo Monteiro (1973), como tendo clima úmido da face oriental e subtropical dos continentes dominados por massa tropical marítima, sendo controlado por massas tropicais e polares. A pluviosidade segue a disposição do relevo e a orientação da costa em relação às correntes de circulação atmosférica regional.

"Enquanto a unidade rítmica é caracterizada pelo maior índice de penetração de massas polares e passagens frontais, a distribuição quantitativa das chuvas varia ao sabor da topografia. Temos aqui o trecho litorâneo paulista exposto no inverno a sensíveis e mais frequentes abaixamentos da temperatura. Mesmo no verão, o seu índice de participação polar é o mais elevado do Estado. As chuvas frontais têm aí grande importância. (...) A faixa mais úmida da costa e sobretudo da face exposta dos maciços isolados cede lugar a uma faixa menos úmida ao longo do curso do Ribeira, voltando a aumentar na encosta de Paranapiacaba. As variações topográficas possibilitam aí uma grande multiplicação de climas locais." (MONTEIRO, 1973).

Sant'anna Neto (1990: 137) chegou a resultados concordantes com a caracterização do clima da região realizada por Monteiro (1973).

"A gênese pluvial da zona costeira paulista está associada à atividade frontal. (...) O setor sul da zona costeira paulista está nitidamente sob o controle das massas polares (PA e PV). (...) O relevo, tanto pela sua altitude, mas principalmente pela sua disposição em relação à direção predominante dos sistemas atmosféricos provenientes do quadrante sul, assume na zona costeira paulista, fato peculiar na gênese pluvial."

Essa região, segundo Monteiro (1973), caracteriza-se por uma unidade rítmica com significativa entrada de massas polares e passagens de sistemas frontais, inclusive no verão. As altas encostas da Serra de Paranapiacaba funcionam como uma barreira para o avanço das massas de ar provenientes do Sul do continente e do Oceano Atlântico, o que faz com 
que as nuvens sejam empurradas para o alto desses paredões se condensando, ocasionando assim, muita chuva e neblina.

O total anual de dias chuvosos no Parque varia de 125 a 150 (SÃO PAULO, 1994), com médias de precipitações oscilando de 1650 a 1900 mm por ano. Janeiro, fevereiro e março são os meses mais chuvosos, enquanto junho, julho e agosto apresentam os menores índices pluviométricos (SÃO PAULO, 2009).

Devido aos elevados índices pluviométricos, a umidade relativa do ar raramente é inferior a $40 \%$ e a média do parque é de $83,4 \%$. O uso do solo e os aspectos da cobertura vegetal são os principais controles desse atributo: áreas com dossel denso e fechado apresentam as maiores umidades relativas do ar (SÃO PAULO, 2009).

A temperatura média anual do Parque é de $18,4^{\circ} \mathrm{C}$, variando de $14,3^{\circ} \mathrm{C}$ no mês mais frio (julho) a $22^{\circ} \mathrm{C}$ no mês mais quente (fevereiro). Nos meses mais quentes, as temperaturas máximas ficam na ordem de $34^{\circ} \mathrm{C}$; já nos mais frios, as temperaturas mínimas absolutas podem chegar a $4^{\circ} \mathrm{C}$ nas altitudes mais elevadas (SÃO PAULO, 2009).

A altitude como um importante controle climático do litoral paulista já foi bastante estudada por vários autores, como, por exemplo, Conti (1975), Sant'anna Neto (1990), Milanesi (2003), Pelegati (2005) e Armani et al (2005 e 2006). Sant'anna Neto demonstra que "de todos os fatores geográficos de localização, nenhum perece ter maior influência na distribuição espacial das chuvas, no território paulista, do que a altimetria" (SANT'ANNA NETO, 1995: 53).

A orografia intensifica a chuva nas vertentes da serra a barlavento do escoamento predominante da baixa troposfera e reduz os totais a sotavento. Também o oceano Atlântico tem papel fundamental na transferência de calor e umidade para a atmosfera adjacente.

Para Monteiro (1975) as unidades espaciais do clima estão muito ligadas às unidades geomorfológicas, pois:

"O clima se posiciona no espaço concreto, tridimensional da superfície terrestre através daquilo que lhe constitui 0 arcabouço - as formas do terreno (p.131). (...) A Serra do Mar não só separa unidades climáticas, entre as baixadas litorâneas quentes e úmidas e os planaltos, mas também influencia nas 
condições de povoamento e ocupação do solo." (MONTEIRO, 1976: 23).

Gutjahr (1993) aponta que a região do Ribeira de Iguape quase não apresenta períodos ou meses secos e que a precipitação é grande parte condicionada pelo relevo. A autora mostrou também a importância da altitude na espacialização da temperatura do ar, além da precipitação pluviométrica, para a região.

"As variações térmicas refletem ainda a influência da compartimentação geomorfológica e da dinâmica da circulação atmosférica em suas respostas espaciais representadas pela variação das chuvas (...) Os resfriamentos mais expressivos são encontrados nos planaltos e serras e os maiores aquecimentos estão ligados às áreas mais secas" (p. 51).

A cobertura vegetal predominante no P. E. Intervales é a Floresta Ombrófila Densa (Floresta Pluvial Tropical), a mais exuberante dos ecossistemas da Mata Atlântica, com grande ocorrência de endemismo. Embora a vegetação do PEI apresente um exuberante vigor vegetativo, trata-se em sua maioria de Mata Secundária derivada de Floresta Ombrófila Densa Montana ou Submontana.

Segundo o Decreto no 750/93, a Mata Atlântica engloba um diversificado mosaico de ecossistemas florestais com estruturas e composições florísticas bastante diferenciadas, grande diversidade biológica e altos graus de endemismo da flora e da fauna, acompanhando a diversidade de solos, relevos e condições climáticas da vasta região onde ocorre. Abrange desde floresta ombrófila densa (figura 4.2) até a semidecidual, passando pela mista. 


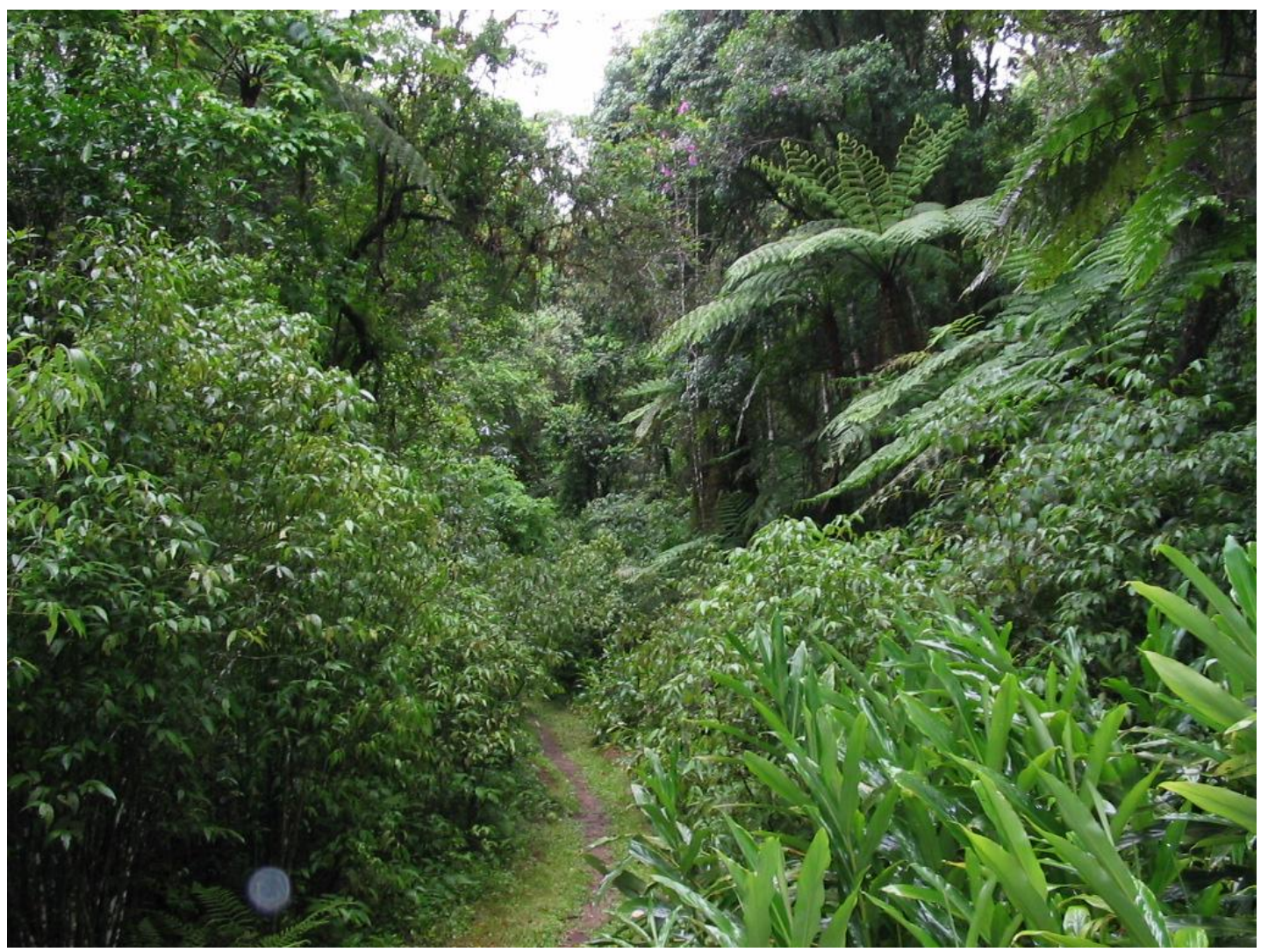

Figura 4.2: Floresta Ombrófila Densa na trilha da Gruta Colorida PEI.

Por George A. Longhitano, 2004

Este domínio tem sido considerado um dos mais notáveis em termos de valor ecológico, por abrigar espécies típicas e atributos biológicos únicos em todo planeta. Esta biodiversidade corresponde à variabilidade de organismos vivos de todas as origens e os complexos ecológicos de que fazem parte compreendendo ainda a diversidade dentro das espécies, entre espécies e de ecossistemas, podendo ser explicada devido à grande variedade altitudinal, e pela sobreposição de dois domínios, o tropical Atlântico e o de Floresta de Araucárias, o que constitui a floresta Ombrófila Mista.

Na área do parque, a medida em que a floresta se interioriza, em direção a norte, recebe uma maior contribuição das espécies vegetais da floresta estacional semidecidual. Fatores como relevo, litologia, solos e clima exercem grande importância para a diversidade da fisionomia da vegetação. 
A litologia do Parque Estadual Intervales, com presença de rochas carbonáticas, especialmente as calcárias, associadas ao clima úmido, à rica drenagem e à exuberante vegetação da região, permitiram o desenvolvimento das cavernas presentes no Parque.

Segundo a resolução CONAMA 347, de 10/09/2004, que dispõe sobre a proteção do patrimônio espeleológico, entende-se por cavidade natural subterrânea "todo e qualquer espaço subterrâneo penetrável pelo ser humano, com ou sem abertura identificada, popularmente conhecido como caverna, gruta, lapa, toca, abismo, furna e buraco, incluindo seu ambiente, seu conteúdo mineral e hídrico, as comunidades bióticas ali encontradas e o corpo rochoso onde as mesmas se inserem, desde que a sua formação tenha sido por processos naturais, independentemente de suas dimensões ou do tipo de rocha encaixante" (BRASIL, 2004).

As cavernas resultam da ação e circulação da água sobre rochas solúveis. Segundo Lino (2001), para haver o desenvolvimento de um relevo cárstico ou para que existam formas cársticas, como as cavernas, é necessária a existência de certas condições básicas:

1) Na região deve haver uma considerável espessura de rocha que seja razoavelmente solúvel em água levemente acidulada (ácido carbônico) proveniente das chuvas e dos cursos de superfície. A rocha deve estar assentada em blocos espessos e contínuos, ser compacta e cristalina e possuir um elevado grau de diaclasamento (juntas e fraturas) e acamamento (camadas rochosas), principalmente em estratos delgados. 0 tipo de rocha que melhor se adapta a essas condições é o calcário;

2) O pacote rochoso deve possuir um "relevo disponível", ou seja, uma elevação da área acima do nível do mar e de porções consideráveis desta acima do lençol freático, o que permite a livre circulação da água subterrânea e o completo desenvolvimento das cavernas;

3) As condições climáticas associadas à cobertura vegetal também contribuem de forma decisiva no desenvolvimento do processo de carstificação e formação de cavernas. Em regiões úmidas, a presença de vegetação densa contribui na acidulação da água e, consequentemente, na dissolução da rocha. 
Como descrito anteriormente, no PEI todas essas condições estão presentes.

Segundo Karmann (2003), as cavernas carbonáticas são formadas a partir da dissolução da calcita (carbonato de cálcio - $\mathrm{CaCO}_{3}$ ) pelo ácido carbônico $\left(\mathrm{H}_{2} \mathrm{CO}_{3}\right)$. O ácido carbônico forma-se quando a água da chuva percola pelo solo da região, rico em matéria orgânica, cuja decomposição gera dióxido de carbono $\left(\mathrm{CO}_{2}\right)$.

$$
\begin{array}{r}
\mathrm{H}_{2} \mathrm{O}+\mathrm{CO}_{2} \rightarrow \mathrm{H}_{2} \mathrm{CO}_{3} \\
\text { água dióxido de ácido } \\
\text { carbono carbônico }
\end{array}
$$

A água acidificada penetra pelas fendas do calcário atacando a rocha e produzindo o bicarbonato de cálcio $\left[\mathrm{Ca}\left(\mathrm{HCO}_{3}\right)_{2}\right]$, que é solúvel e facilmente transportado pela água. As fendas alargam-se lentamente, formando as cavidades subterrâneas.

$$
\mathrm{H}_{2} \mathrm{CO}_{3}+\mathrm{CaCO}_{3} \rightarrow \mathrm{Ca}\left(\mathrm{HCO}_{3}\right)_{2}
$$

ácido carbonato bicarbonato

carbônico de cálcio de cálcio

Quando a caverna já está formada, o bicarbonato de cálcio transportado emerge no teto da caverna até atingir volume e peso suficiente para cair. Nesse momento, ocorre a liberação do gás carbônico e precipitação do carbonato de cálcio, que darão origem as estalactites (figura 4.3).

$$
\begin{array}{ll}
\mathrm{Ca}\left(\mathrm{HCO}_{3}\right)_{2} & \rightarrow \mathrm{CaCO}_{3}+\mathrm{H}_{2} \mathrm{O}+\mathrm{CO}_{2} \\
\begin{array}{c}
\text { bicarbonato } \\
\text { de cálcio }
\end{array} & \begin{array}{c}
\text { carbonato } \\
\text { de cálcio }
\end{array}
\end{array} \text { água } \begin{gathered}
\text { dióxido de } \\
\text { carbono }
\end{gathered}
$$




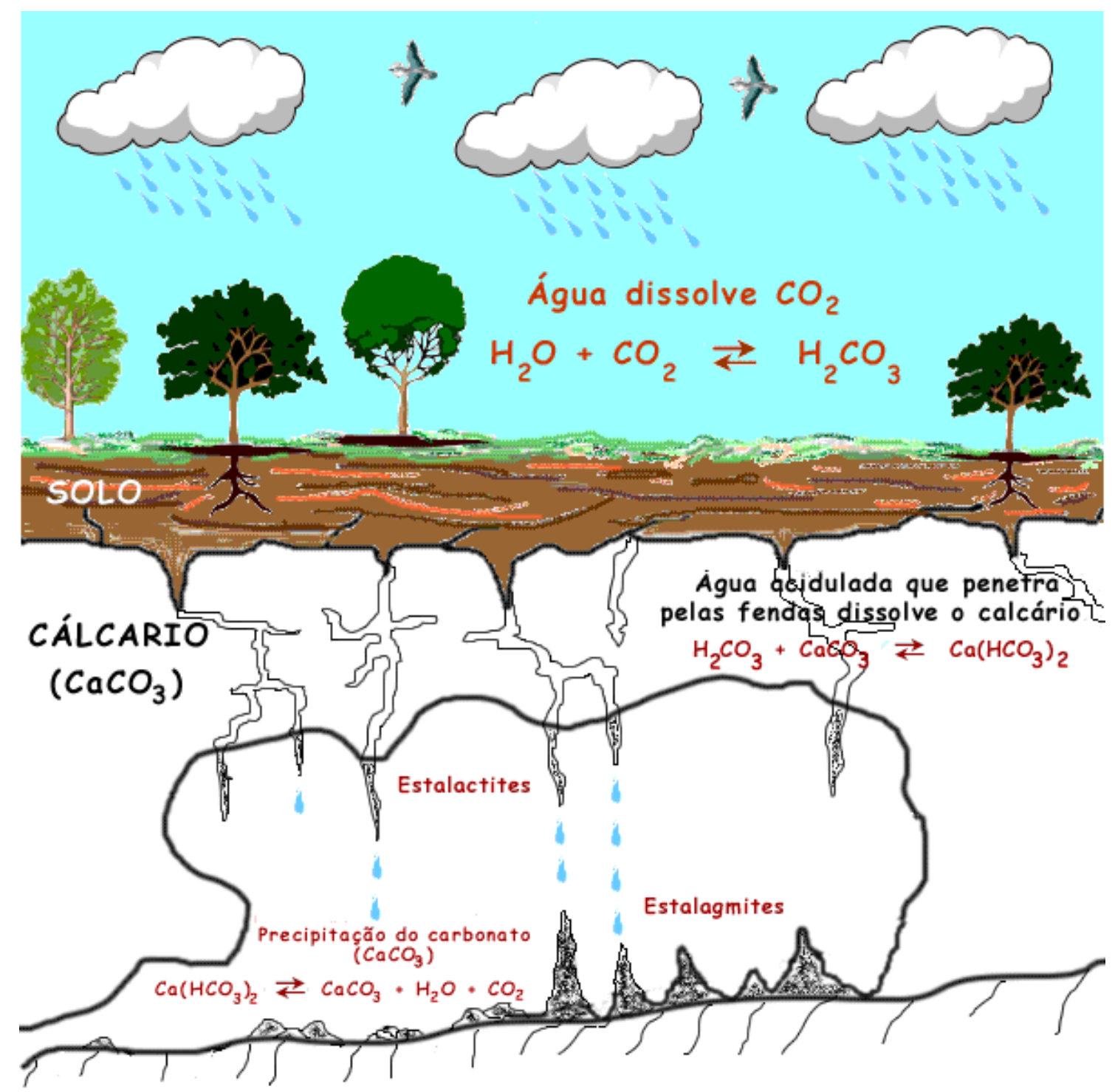

Figura 4.3: Formação de cavernas calcárias.

Fonte: http://www.cdcc.usp.br/quimica/ciencia/cavernas.html

Assim, condicionantes geológicas, geomorfológicas, climáticas e da vegetação agem de forma conjunta e articulada no processo de espeleogênese. Este é um processo dinâmico e as cavernas dela originadas devem ser entendidas não como produtos acabados, mas sim como componentes subterrâneos de um relevo em contínua evolução.

Devido a essas condições, o Vale do Ribeira é a área de maior importância espeleológica das regiões sudeste e sul do Brasil, abrangendo porções dos estados do Paraná e São Paulo (LINO, 2001) 
O Parque Estadual Intervales possui dezenas de cavernas, formadas a partir da dissolução do calcário. O mapa a seguir (figura 4.4) apresenta as cavernas mais visitadas do Parque, objetos de estudo desta pesquisa.

Figura 4.4: Localização das cavernas objetos de estudo do Parque Estadual Intervales.

Por George A. Longhitano, 2010. Fonte: Instituto EKOS, 2009. 


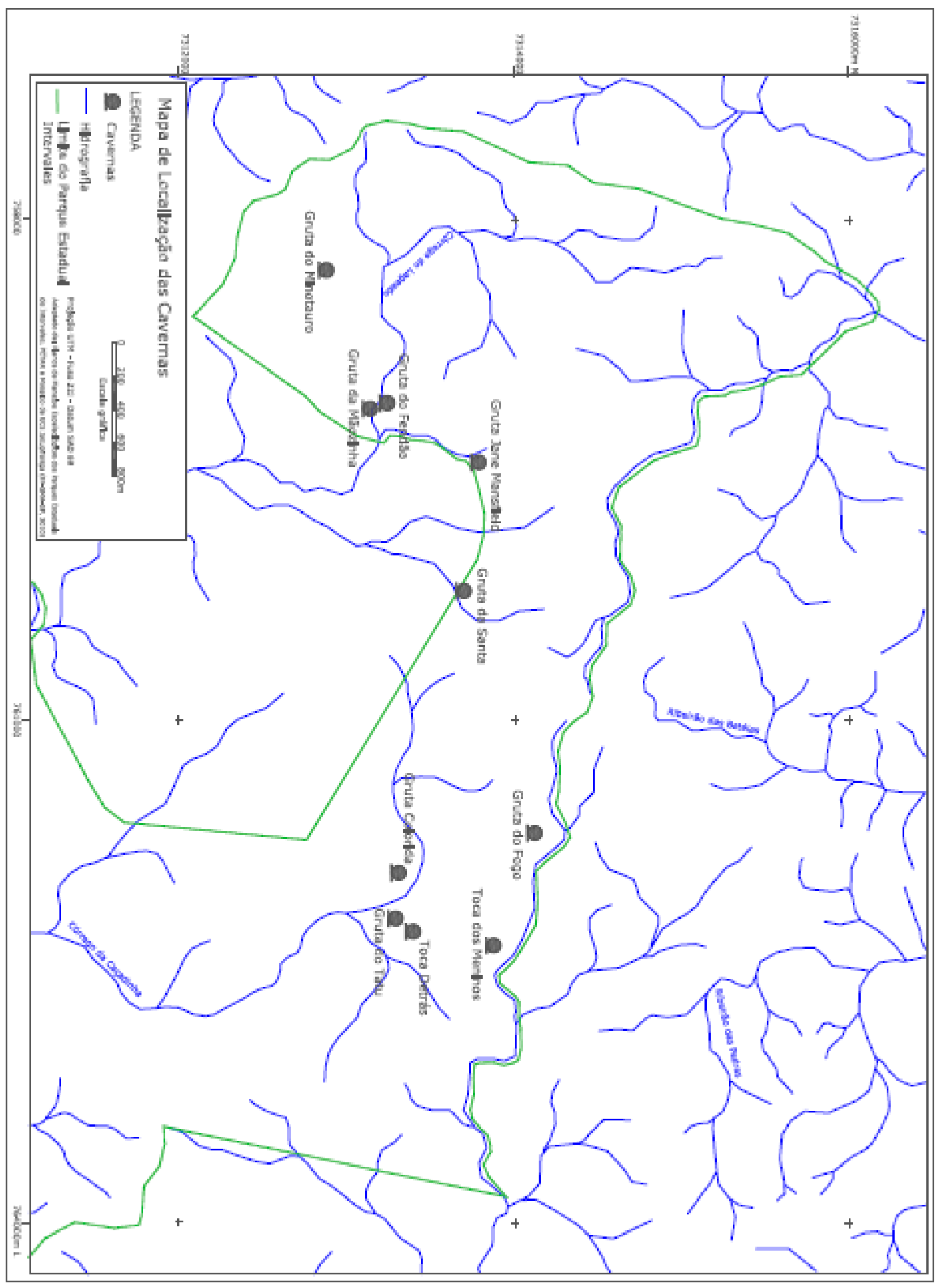


Próximo à sede do Parque, localizam-se as grutas do Tatu, Detrás (ou Cipó), do Fogo e dos Meninos. As cavernas do núcleo Sede são de pequena extensão (tabela 4.1) e, consequentemente, pouco procuradas pelos visitantes.

Tabela 4.1: Extensão aproximada das grutas estudadas

\begin{tabular}{|c|c|c|c|}
\hline \multicolumn{2}{|c|}{ Agrupamento Sede } & \multicolumn{2}{|c|}{$\begin{array}{c}\text { Agrupamento Bocaina/ } \\
\text { Lageado }\end{array}$} \\
\hline Gruta & Extensão (m) & Gruta & Extensão (m) \\
\hline Tatu & 32 & Fendão & 1120 \\
\hline Detrás & 60 & Mãozinha & 54 \\
\hline Fogo & 126 & $\begin{array}{l}\text { Jane } \\
\text { Mansfield }\end{array}$ & 500 \\
\hline Meninos & 30 & Santa & 49 \\
\hline & & Minotauro & 560 \\
\hline
\end{tabular}

Organização: Bárbara N. Rocha, 2010. Fonte: SÃO PAULO, 2009.

A gruta do Tatu possui poucas formações e nela podem ser vistos morcegos e opilhões. Apresenta claraboias e um rio de águas correntes. $\mathrm{O}$ circuito de visitação se faz em um trecho de apenas $25 \mathrm{~m}$.

A gruta do Cipó é seca, ou seja, não é cortada por rio, e possui formações como estalagmites e estalactites. É habitada por morcegos e tem extensão aproximada de $60 \mathrm{~m}$.

A toca dos Meninos também é seca e a menor dentre as estudadas sua extensão é inferior a 30m. O acesso se dá por uma entrada estreita, próxima à pousada Mono Carvoeiro. É habitada por morcegos e opilhões.

Já a gruta do Fogo tem uma extensão aproximada de $130 \mathrm{~m}$ e possui um pequeno rio de águas calmas. Não apresenta espeleotemas em seu interior.

No agrupamento Bocaina-Lageado, foram estudadas as grutas da Santa, Jane Mansfield, do Minotauro, do Fendão e da Mãozinha. Destas, a gruta do Fendão, com mais de um quilômetro de extensão e rio caudaloso, repleto de quedas d'água, é a mais visitada. Jane Mansfield, Santa e Minotauro, de média extensão, apresentam média visitação. Apenas a da 
Mãozinha, a menor caverna deste agrupamento, pouco recebe turistas. A gruta da Mãozinha fica ao lado da gruta do Fendão; não possui rio, mas apresenta alguns espeleotemas e é recoberta de lama.

A gruta Jane Mansfield apresenta uma entrada estreita e é toda cortada por um rio encachoeirado. Nela pode-se encontrar formações do tipo estalagmites, estalactites, cortinas, travertinos e colunas.

A gruta da Santa possui algumas estalactites e represas de travertino no piso. Seu ambiente seco proporciona a presença de morcegos e opilhões. Uma imagem de Nossa Senhora de Lourdes está presente em sua entrada, junto a um altar, conferindo um uso turístico de cunho religioso à gruta (figura 4.5).

Por fim, a gruta do Minotauro recebe esse nome devido a seus corredores estreitos e labirínticos. Possui

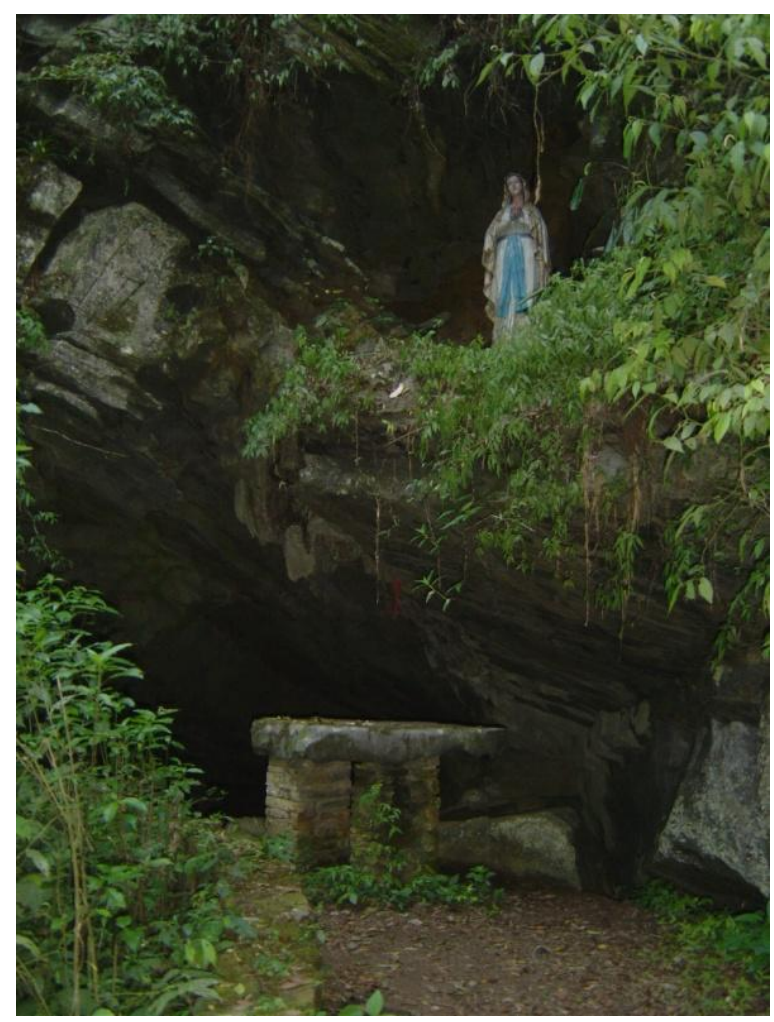

Figura 4.5: Entrada da Gruta da Santa. Por Bárbara N. Rocha, 2007. uma extensão de, aproximadamente, $560 \mathrm{~m}$ e é cortada por um pequeno rio. Há formações de estalagmites, estalactites e cortinas.

Para facilitar o entendimento do microclima cavernícola, cada uma dessas grutas serão melhor descritas no capítulo 4 - Resultados.

No interior dessas cavernas encontram-se depósitos de sedimentos acumulados nos seus pisos e reentrâncias. Encontram-se, também, deposições minerais que recobrem e se desenvolvem a partir dos tetos e paredes da cavidade. Considerando-se suas origens e processos deposicionais, tais sedimentos são divididos em dois grandes grupos, segundo Lino (2001):

$\checkmark$ Sedimentos clásticos: constituídos pelos blocos desmoronados e pelo material detrítico de origem geralmente superficial transportado para a 
caverna por correntes d'água, vento ou pela gravidade. São também frequentes frações síltico-argilosas ou até arenosas provenientes da alteração e posterior erosão da rocha encaixante da caverna.

$\checkmark$ Espeleotemas: do grego spelaion (caverna) e thema (depósito). Definem-se como deposições minerais em cavernas que se formam basicamente por processos químicos de dissolução e precipitação.

Os espeleotemas podem ser classificados em três grupos: depósitos de águas circulantes, depósitos de água de exudação e depósitos de águas estagnadas. Esta classificação leva em consideração as formas e os estilos dos espeleotemas.

Os depósitos de águas circulantes representam os espeleotemas formados pela deposição do carbonato de cálcio contido em soluções aquosas que se movem nas cavernas por força da gravidade, como as estalactites, estalagmites, cortinas, colunas, represas de travertino e pérolas de caverna. Tais espeleotemas recobrem tanto os tetos e paredes da caverna, como também seu piso, sendo formados pelos dois mecanismos de deposição básicos: gotejamento e escorrimento. Este tipo de espeleotema é o mais encontrado nas cavernas estudadas.

As eslalactites são os espeleotemas mais comumente encontrados. Gotas de água contendo carbonato de cálcio em solução, ao saírem das fissuras do teto da caverna, ficam presas a eles por alguns minutos até atingir um volume com peso suficiente para vencer a tensão superficial e cair. Neste tempo, libera-se o anidrido carbônico na atmosfera cavernícola, a solução fica supersaturada e precipita-se, então, um delicado anel de calcita, no contato da gota com o teto. As estalactites crescem verticalmente do teto para o piso da caverna (figura 4.6). 

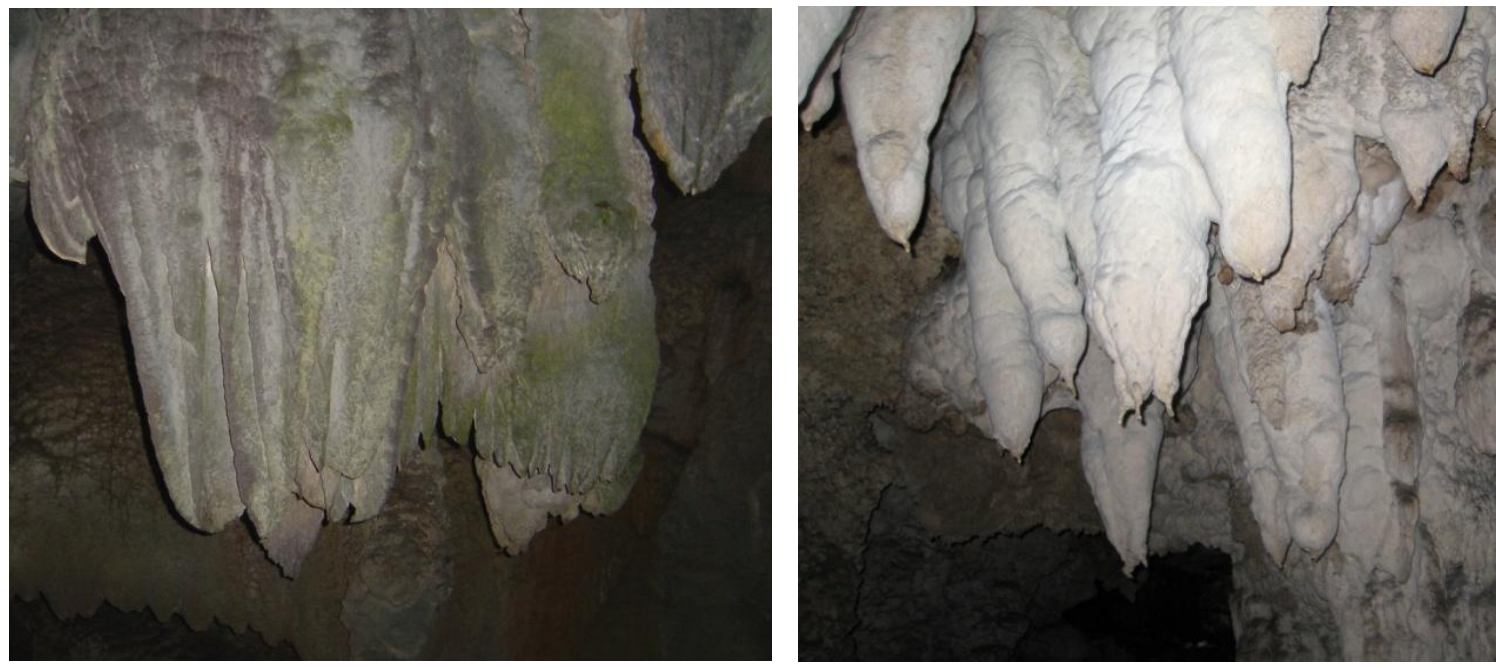

Figura 4.6: Estalactites das Grutas Detrás e Minotauro, respectivamente. Por Bárbara N. Rocha, 2009.

As estalagmites formam-se quando as gotas que caem do teto ou de uma estalactite, ao chocar-se contra o piso da caverna, deixam precipitar a calcita que ainda traziam dissolvidas. Elas crescem verticalmente a partir do solo (figura 4.7).

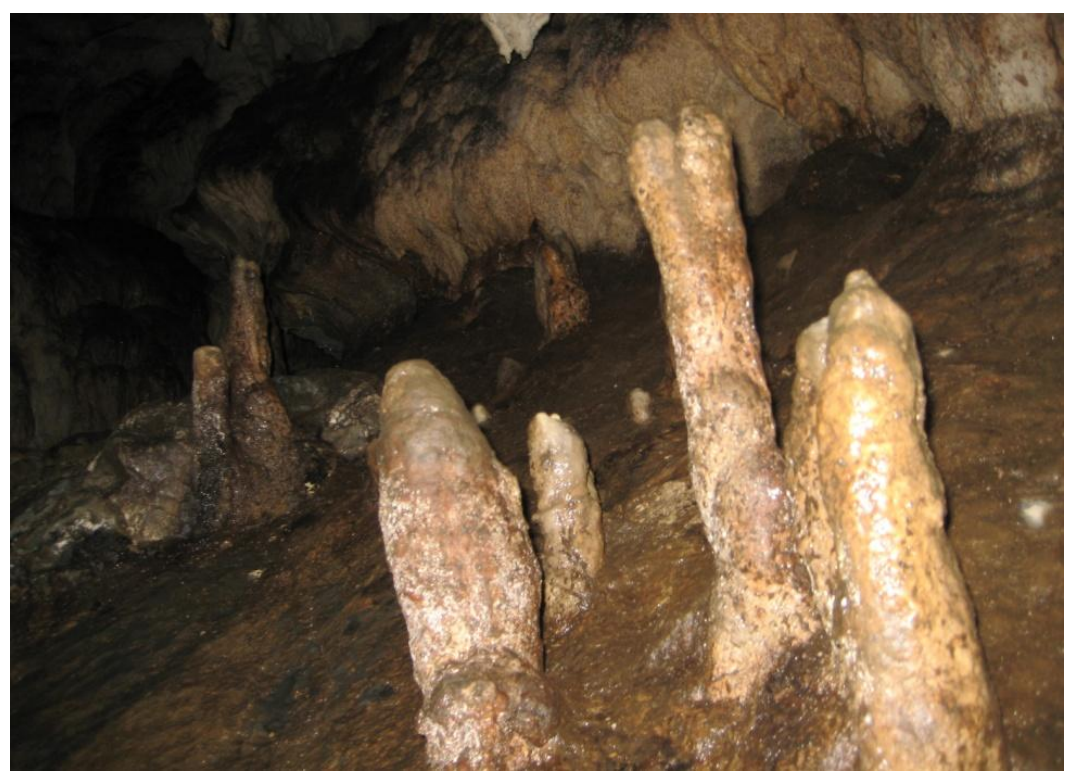

Figura 4.7: Estalagmites da Gruta Jane Mansfield. Por Mariana Rocha, março de 2009

As cortinas formam-se quando as gotas d'água emergem em uma parede ou teto inclinado, escorrendo pela sua superfície, deixando um fino rastro de $\mathrm{CaCO}_{3}$ que, com a continuidade do processo, cresce verticalmente 
dando origem a uma lâmina de calcita ondulada, branca e translúcida (figura 4.8).

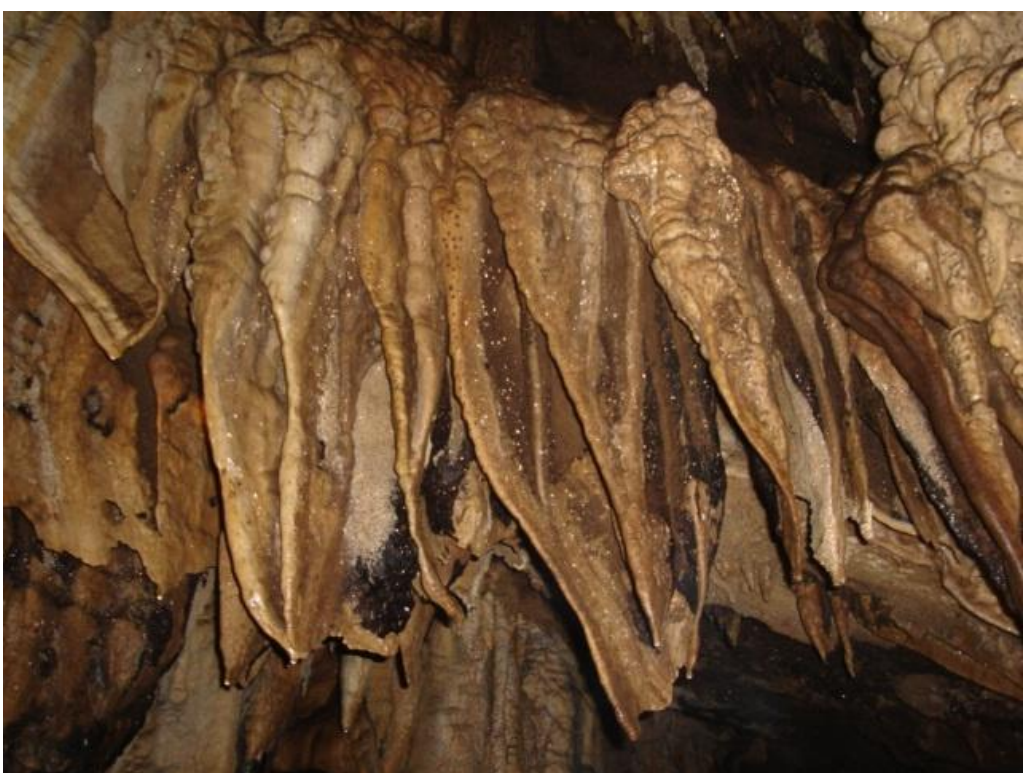

Figura 4.8: Cortinas na Gruta do Minotauro.

Por Silvia Zambuzi, 2007.

As colunas são as formas verticais e, geralmente, cilíndricas que se originam da união de estalactites e estalagmites ou do crescimento exagerado de uma delas, unindo teto e piso das galerias e salões das cavernas.

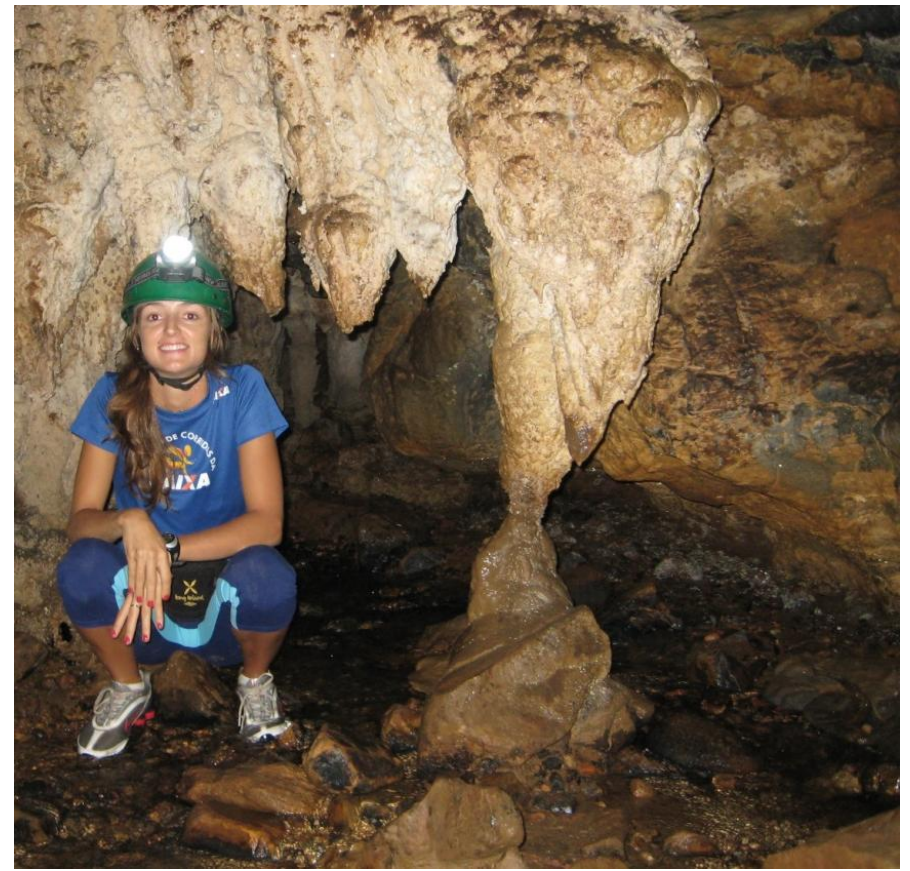

Figura 4.9: Coluna da Gruta do Minotauro.

Por Bárbara N. Rocha, 2009. 
Os depósitos de águas de exudação são os espeleotemas formados a partir das soluções aquosas que, por capilaridade, circulam lenta e descontinuamente pelos poros da rocha envolvente da caverna. Diversos fatores, como a diferença de temperatura e pressão entre os poros da rocha e o vazio das cavernas, fazem estas soluções emergirem das paredes, depositando a calcita até então dissolvida. Os espeleotemas representantes desse grupo são: corais, escudos, helictites, flores de caverna, agulhas, entre outros. Deste grupo de espeleotemas, apenas helectites puderam ser observadas nas cavernas pesquisadas.

Por fim, os depósitos de águas estagnadas são os espeleotemas originados a partir da deposição de minerais nas partes submersas ou superficiais dos represamentos de água existentes nos pisos das cavernas, como, por exemplo, os geodos de calcita, não encontrados no Parque.

No próximo capítulo (5), são apresentados e discutidos os resultados dos estudos microclimáticos desenvolvidos nas cavernas apresentadas. 


\section{Resultados e discussões}

\section{1 - Gruta Detrás (Cipó)}

A Gruta do Cipó apresenta pequena extensão e constitui-se de uma única galeria. É uma cavidade sem cursos de água corrente, porém com elevado grau de gotejamento. Apresenta algumas claraboias na parte central, permitindo maior ventilação e entrada de radiação solar difusa.

Os trabalhos de campo para coleta de dados na Gruta foram realizados entre os dias 5 e 13 de fevereiro de 2009. A figura 5.1.1 mostra os locais onde foram instalados os termohigrômetros.

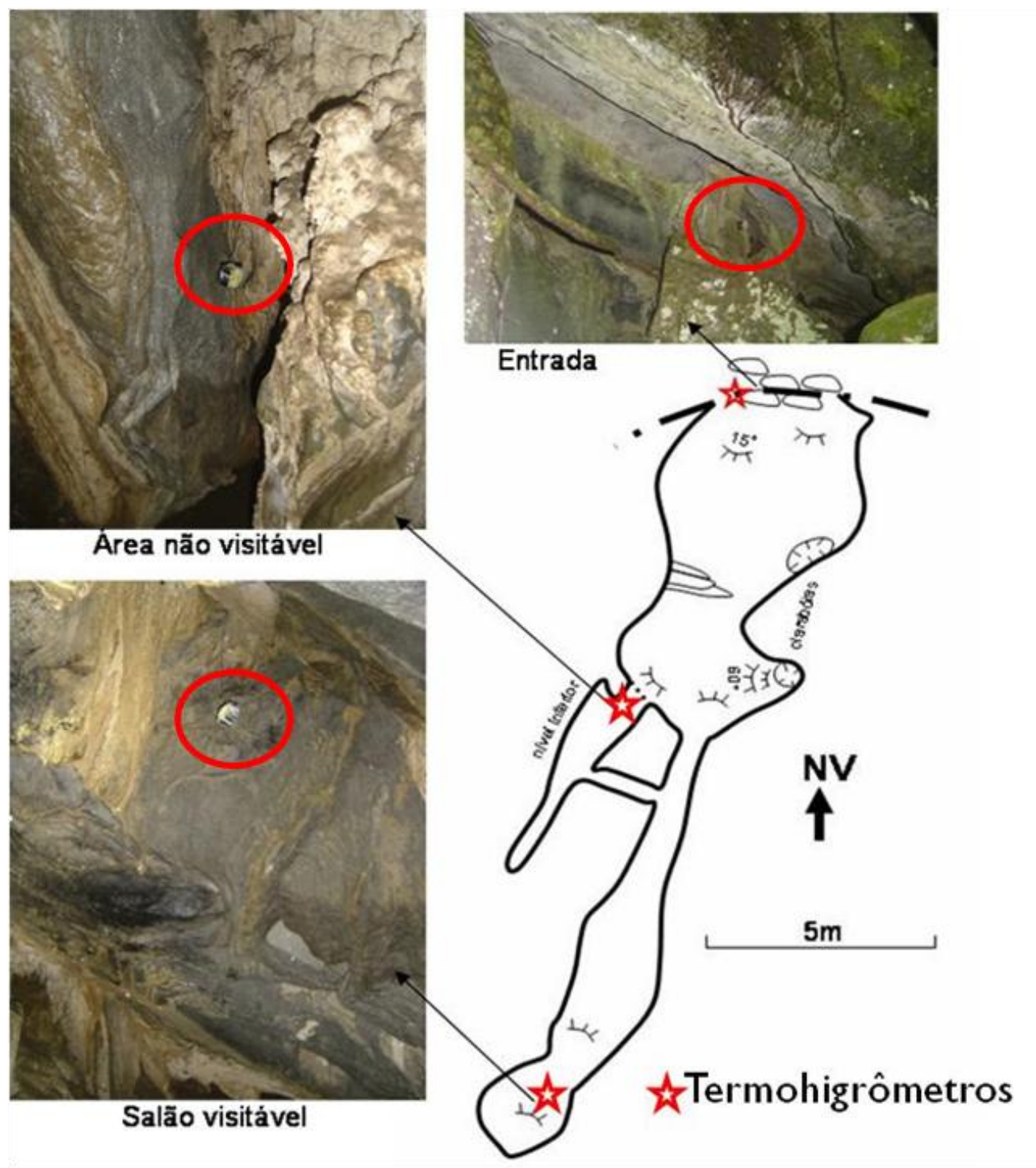

Figura 5.1.1: Localização dos termohigrômetros na Gruta Detrás. Organização e fotografias: Bárbara N. Rocha, 2009. Fonte: Instituto EKOS, 2009. 
O primeiro foi instalado na entrada da gruta, em uma fenda da rocha para protegê-lo das chuvas. A presença de floresta ombrófila no meio externo faz com que neste local incida apenas radiação solar difusa. Este ponto caracteriza o microclima transicional, entre o ambiente externo e o subterrâneo.

O segundo sensor, denominado de "salão visitável", foi instalado no final da galeria, em um salão mais estreito e fechado, com entrada de luz e circulação atmosférica dificultada devido ao estreitamento do corredor e ausência de claraboias.

Por constituir-se de uma única galeria, praticamente não há áreas na gruta por onde o turista não circule, o que dificultou a escolha de um local para a instalação do terceiro termohigrômetro (periférico a uma área visitável). Assim, o último equipamento foi alocado em uma pequena entrada que há no meio da galeria. Esta reentrância é pequena e fica muito próxima ao corredor de circulação. Porém, é o único ponto da caverna que não há passagem de turistas.

A tabela 5.1.1 apresenta alguns parâmetros estatísticos (média, máximo e mínimo valor, amplitude, moda, variância e desvio padrão) dos dados de temperatura e umidade relativa do ar obtidos nos três pontos de análise durante o período de uma semana.

Tabela 5.1.1: Parâmetros estatísticos da temperatura e umidade relativa do ar da Gruta do Cipó (período de 5 a 13/02/2009).

\begin{tabular}{|c|ccc|ccc|}
\cline { 2 - 7 } \multicolumn{1}{c|}{} & \multicolumn{3}{c|}{ Temperatura do ar $\left({ }^{\circ} \mathrm{C}\right)$} & \multicolumn{3}{c|}{ Umidade Relativa do ar (\%) } \\
\cline { 2 - 7 } \multicolumn{1}{c|}{} & Entrada & $\begin{array}{c}\text { Salão } \\
\text { visitável }\end{array}$ & $\begin{array}{c}\text { Salão não } \\
\text { visitável }\end{array}$ & Entrada & $\begin{array}{c}\text { Salão } \\
\text { visitável }\end{array}$ & $\begin{array}{c}\text { Salão não } \\
\text { visitável }\end{array}$ \\
\hline média & 19,5 & 17,8 & 18,9 & 100,0 & 100,0 & 99,2 \\
máximo & 22,7 & 18,5 & 19,9 & 100,0 & 100,0 & 100,0 \\
mínimo & 16,7 & 16,4 & 18,0 & 100,0 & 100,0 & 70,8 \\
amplitude & 6,0 & 2,1 & 1,9 & 0,0 & 0,0 & 29,2 \\
moda & 19,4 & 18,3 & 18,8 & 100,0 & 100,0 & 100,0 \\
desvio padrão & 1,2 & 0,8 & 0,4 & 0,0 & 0,0 & 3,8 \\
variância & 1,5 & 0,6 & 0,2 & 0,0 & 0,0 & 14,4 \\
\hline
\end{tabular}

Organização: Bárbara N. Rocha, 2010.

A média das temperaturas no período de estudo foi de $19,5^{\circ} \mathrm{C}$ na entrada da caverna, $18,9^{\circ} \mathrm{C}$ no meio da galeria (salão não visitavel) e 
$17,8^{\circ} \mathrm{C}$ no final da cavidade (salão visitável). Percebe-se que quanto mais se adentra na caverna, menor a temperatura. A amplitude térmica média entre o ambiente externo e o interno foi de $1,7^{\circ} \mathrm{C}$.

A temperatura máxima registrada no período foi de $22,7^{\circ} \mathrm{C}$ na entrada da caverna, onde é possível a entrada de radiação solar difusa. A mínima $\left(16,4^{\circ} \mathrm{C}\right)$ ocorreu no final da galeria, onde não há entrada de luz, dificultando o aquecimento da atmosfera. Na entrada, a amplitude térmica semanal foi de $6^{\circ} \mathrm{C}$, enquanto no ambiente interno foi bem inferior, próxima a $2^{\circ} \mathrm{C}$.

A moda das amostras apresentou valores muito próximos à média. Isso indica que não houve muitas flutuações ambientais no período analisado, o que pode ser comprovado pelos baixos valores de variância e desvio padrão, pois, quanto menor a variância, menos os valores observados se distanciaram da média.

A umidade relativa do ar apresenta médias próximas ou igual a $100 \%$ nos três pontos estudados. Isso comprova a elevada umidade do ar no ambiente subterrâneo. O máximo registrado em todos os pontos foi de 100\%, enquanto o mínimo chegou a 70,8\% na área não visitável.

A amplitude no meio da galeria foi de 29,2 e na entrada e no final do corredor a UR não variou, estando o ar saturado durante todo o período. A variação no último ponto ocorre pela incidência de radiação solar difusa e maior ventilação por causa da presença de claraboias.

A moda das amostras estiveram sempre em 100\%. Assim, em todos os locais analisados, o ar encontrou-se saturado na maior parte do tempo.

A variância e o desvio padrão do meio da galeria são elevados, devido às grandes amplitudes encontradas.

O gráfico a seguir (figura 5.1.2) apresenta a variação da temperatura do ar nos três pontos estudados, durante o período de uma semana. Optouse por um gráfico em dois eixos para melhor visualização das amplitudes do meio interno (salão visitável e salão não-visitável), já que os dados do meio externo (entrada) são mais variáveis.

Nesta primeira semana de campo, a estação meteorológica externa apresentou problemas ao baixar os dados. Assim, não há comparativo do microclima desta gruta com o do meio externo. 


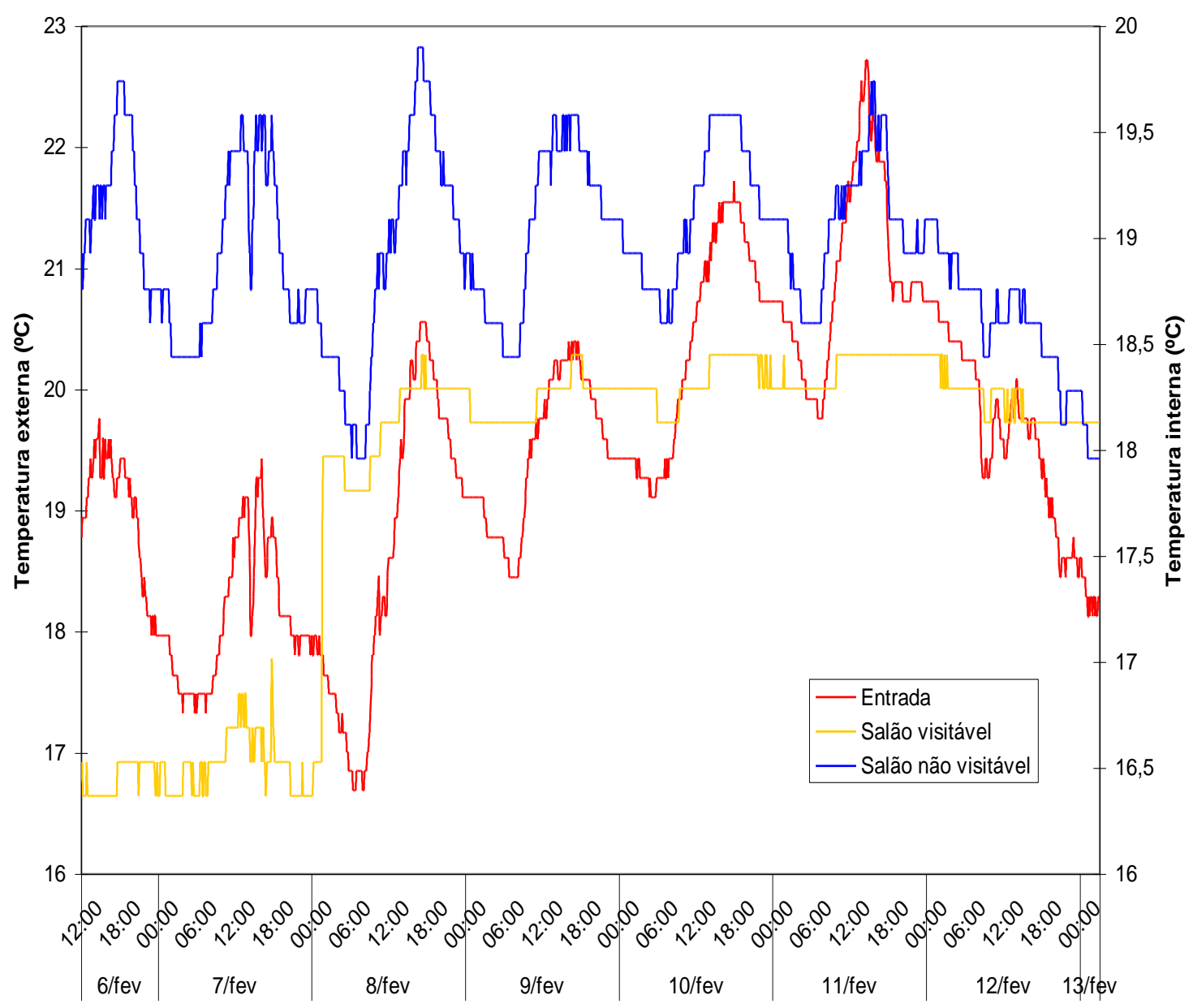

Figura 5.1.2: Variação da temperatura do ar $\left({ }^{\circ} \mathrm{C}\right)$ na Gruta do Cipó. Organização: Bárbara N. Rocha, 2010.

Nota-se que na entrada da caverna são encontradas as maiores amplitudes térmicas. A temperatura do ar acompanha o ciclo diuturno devido à maior incidência de radiação solar neste ponto.

$\mathrm{Na}$ medida em que se adentra na gruta, as amplitudes térmicas e a temperatura do ar diminuem gradativamente. No meio da galeria (área não visitável) a temperatura ainda apresenta alternância entre o dia e a noite, porém com menor amplitude térmica. Quase não se percebem atrasos na assimilação do tempo exterior. Isso ocorre porque este ponto está em uma zona de penumbra, com iluminação natural incidente da entrada da gruta e de claraboias.

No final da galeria, as variações decorrentes do tempo exterior ainda são percebidas, porém com amplitudes bem inferiores. A diminuição ou aumento de temperatura ocorrem quase que simultaneamente as 
alterações do meio externo. Tal fato indica que esta caverna apresenta baixa suscetibilidade a alterações microclimáticas decorrentes de visitação humana, pois apresenta alta troca e fluxo de energia em seu interior.

Durante o período de coleta de dados, foi realizada uma visitação na Gruta. Esta ocorreu no dia 7, onde um grupo de 5 pessoas ficou na cavidade das $17 \mathrm{~h} 30 \mathrm{~min}$ às $17 \mathrm{~h} 50 \mathrm{~min}$. A variação da temperatura do ar no momento da visitação pode ser mais facilmente visualizado na figura a seguir (figura 5.1.3).

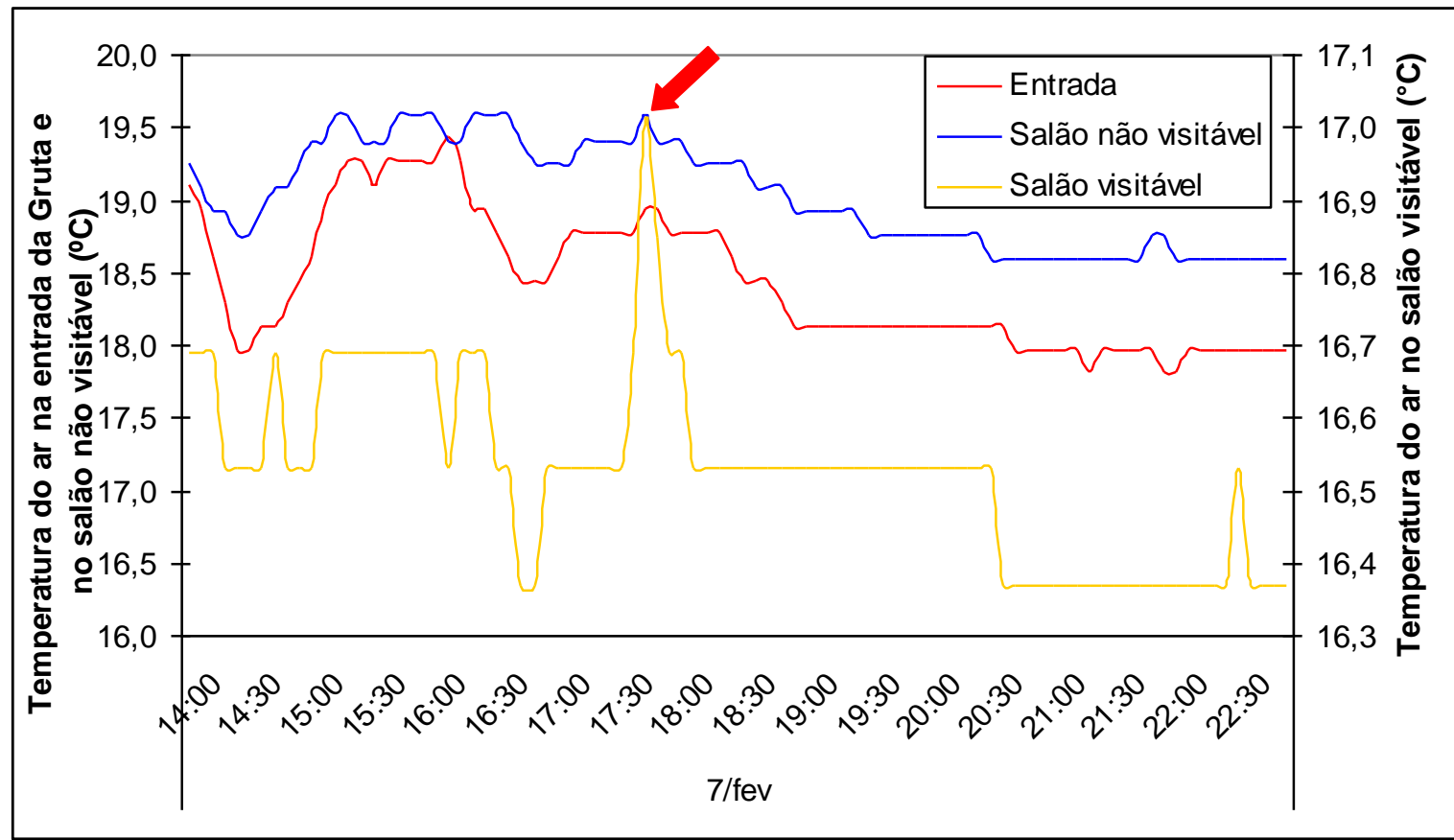

Figura 5.1.3: Variação horária da temperatura do ar $\left({ }^{\circ} \mathrm{C}\right)$ na Gruta do Cipó no dia 7 de fevereiro.

Organização: Bárbara N. Rocha, 2010.

Pela análise da figura 5.1.3, percebe-se que, no momento da entrada dos turistas, a temperatura do ar do final da galeria apresentou um aumento de $0,4^{\circ} \mathrm{C}$, passando de $16,5^{\circ} \mathrm{C}$ às $17 \mathrm{~h} 30 \mathrm{~min}$ para $16,9^{\circ} \mathrm{C}$ às 17h50min. A cavidade retornou a situação de estabilidade às $18 \mathrm{~h} 05 \mathrm{~min}$. Este fato indica impacto na atmosfera cavernícola decorrente da visitação turística, corroborando os resultados encontrados por Viana Júnior (2002), Sánchez-Martos et al (2002), Longhitano et al (2006) e Rocha et al (2006).

O impacto detectado deve ser analisado com cautela, pois, no momento da visitação, a temperatura do meio externo também apresentou 
curva ascendente, aumentando $0,1^{\circ} \mathrm{C}$. No meio da galeria, onde as variações ainda acompanham o ciclo diuturno, o aumento neste período foi de $0,2^{\circ} \mathrm{C}$. Uma provável abertura no céu, com diminuição da nebulosidade, pode ter facilitado a entrada de radiação difusa na caverna ao final do dia. A análise da figura 5.1.2 mostrou que o salão visitável responde às alterações climáticas do meio externo. Logo, o aumento da temperatura do ar no final da galeria pode, em parte, ter sido decorrente de variações climáticas externas.

Quanto à magnitude do impacto, uma alteração de $0,4^{\circ} \mathrm{C}$ em 15 minutos no ponto mais interno da cavidade não é significativa, pois variações bem maiores, de ordem natural, foram encontradas já na madrugada do dia 8 , quando a temperatura deste mesmo ponto se elevou em $1,5^{\circ} \mathrm{C}$ em um intervalo de tempo inferior a 15 minutos.

A figura 5.1.4 mostra as variações da umidade relativa do ar na Gruta do Cipó.

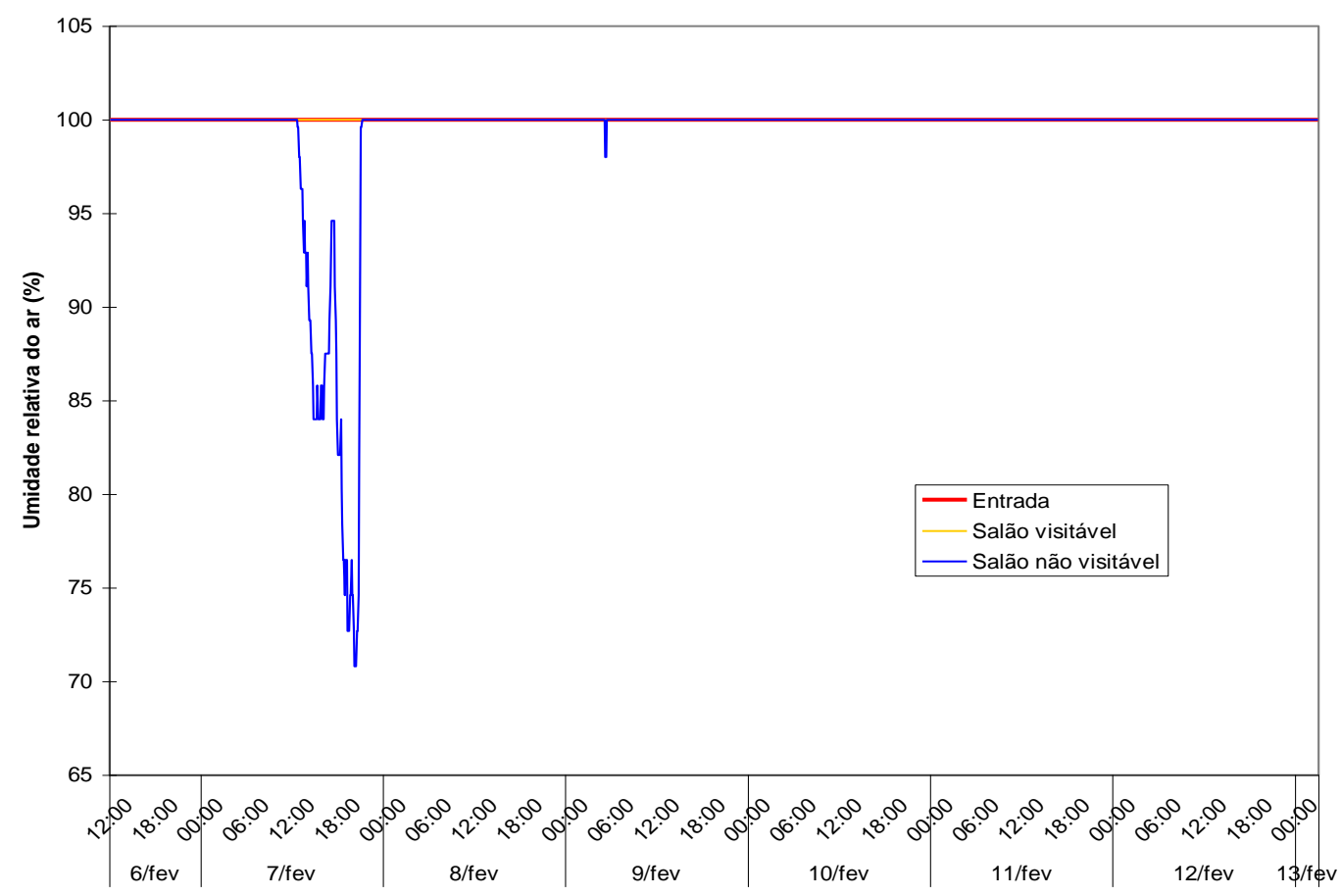

Figura 5.1.4: Variação da umidade relativa do ar (\%) na Gruta do Cipó.

Organização: Bárbara N. Rocha, 2010.

$\mathrm{Na}$ maior parte do período de medidas, o ar encontrou-se saturado nos três locais de coleta, inclusive na entrada da caverna. Este fato explica- 
se pela realização do trabalho de campo em período chuvoso e pela umidade proveniente da mata no meio exterior à gruta. No meio subterrâneo, a umidade tende a saturação devido à baixa incidência de radiação solar, a proteção do ambiente pela capa rochosa e ao gotejamento dos espeleotemas.

Pela análise do gráfico (figura 5.1.4), percebe-se que no dia 7 de fevereiro, o sensor instalado no meio da galeria (área não visitável) apresentou variação na umidade relativa do ar, que atingiu um mínimo de 70,8\%. Dois fatores podem explicar esse fenômeno: 1) A localização deste ponto próximo a claraboias, que permite uma maior entrada de radiação solar neste local e consequente aumento da temperatura e diminuição da UR (figura 5.1.2); 2) A presença de cinco turistas na cavidade, cuja iluminação e calor corporal podem influenciar no microclima do ambiente subterrâneo.

Ressalta-se que a diminuição da umidade relativa do ar neste local já pôde ser notada no início do dia, desde às 9h40min, atingindo o mínimo às 17h10min e voltando ao estágio de saturação às $18 \mathrm{~h} 10 \mathrm{~min}$ (figura 5.1.5). Os turistas só entraram na gruta às $17 \mathrm{~h} 30 \mathrm{~min}$, horário em que a atmosfera apresentava aumento da umidade relativa do ar. Assim, a primeira hipótese mostra-se mais coerente, não podendo ser comprovada a alteração da umidade relativa em decorrência do turismo.

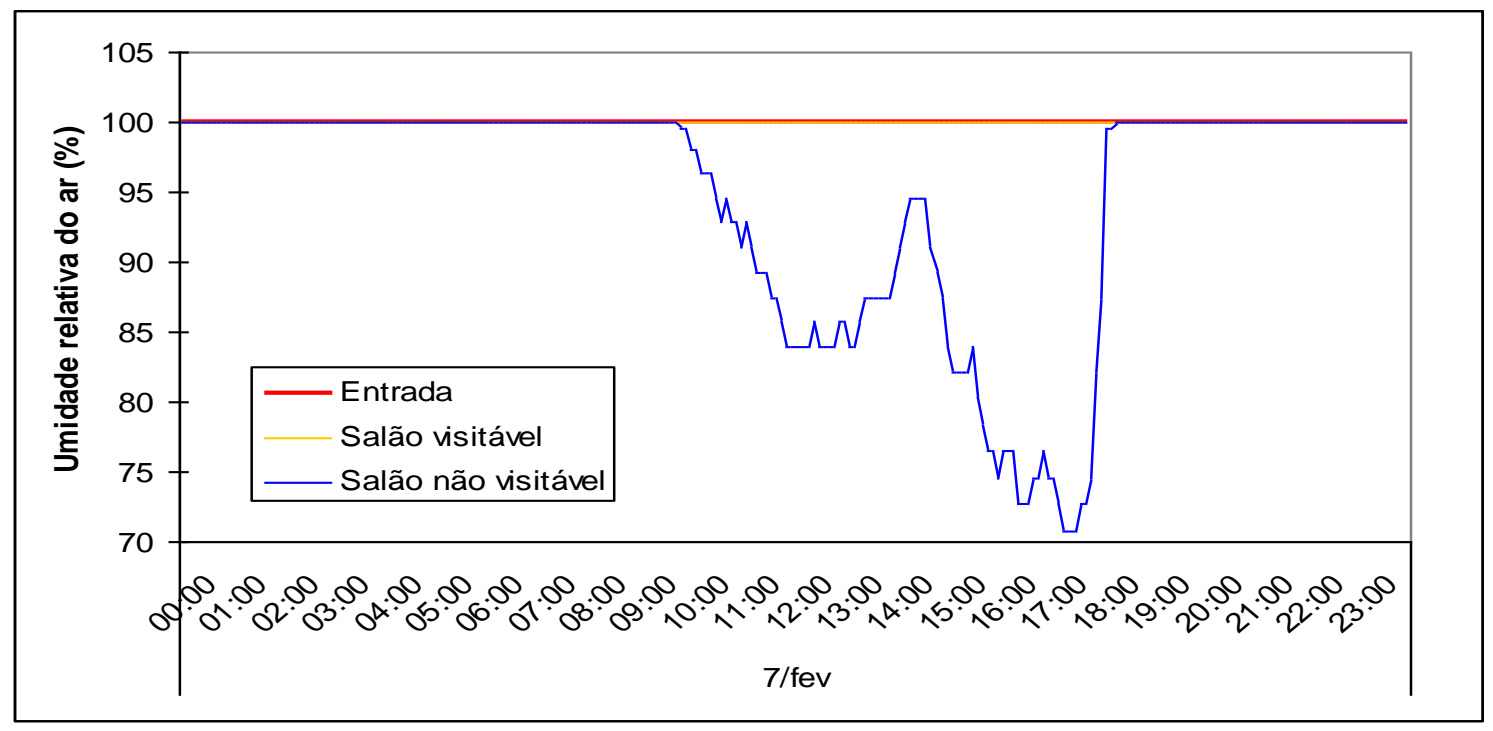

Figura 5.1.5: Variação horária da umidade relativa do ar (\%) na Gruta do Cipó no dia 7 de fevereiro de 2009.

Organização: Bárbara N. Rocha, 2010. 
A figura a seguir (figura 5.1.6) mostra o perfil do dióxido de carbono da cavidade estudada na presença de três turistas. Os dados foram coletados na manhã do dia 13 de fevereiro. No croqui da gruta podem ser observados os 10 pontos de coletas de dados, sendo o primeiro na entrada e o décimo no ponto mais interior da gruta.

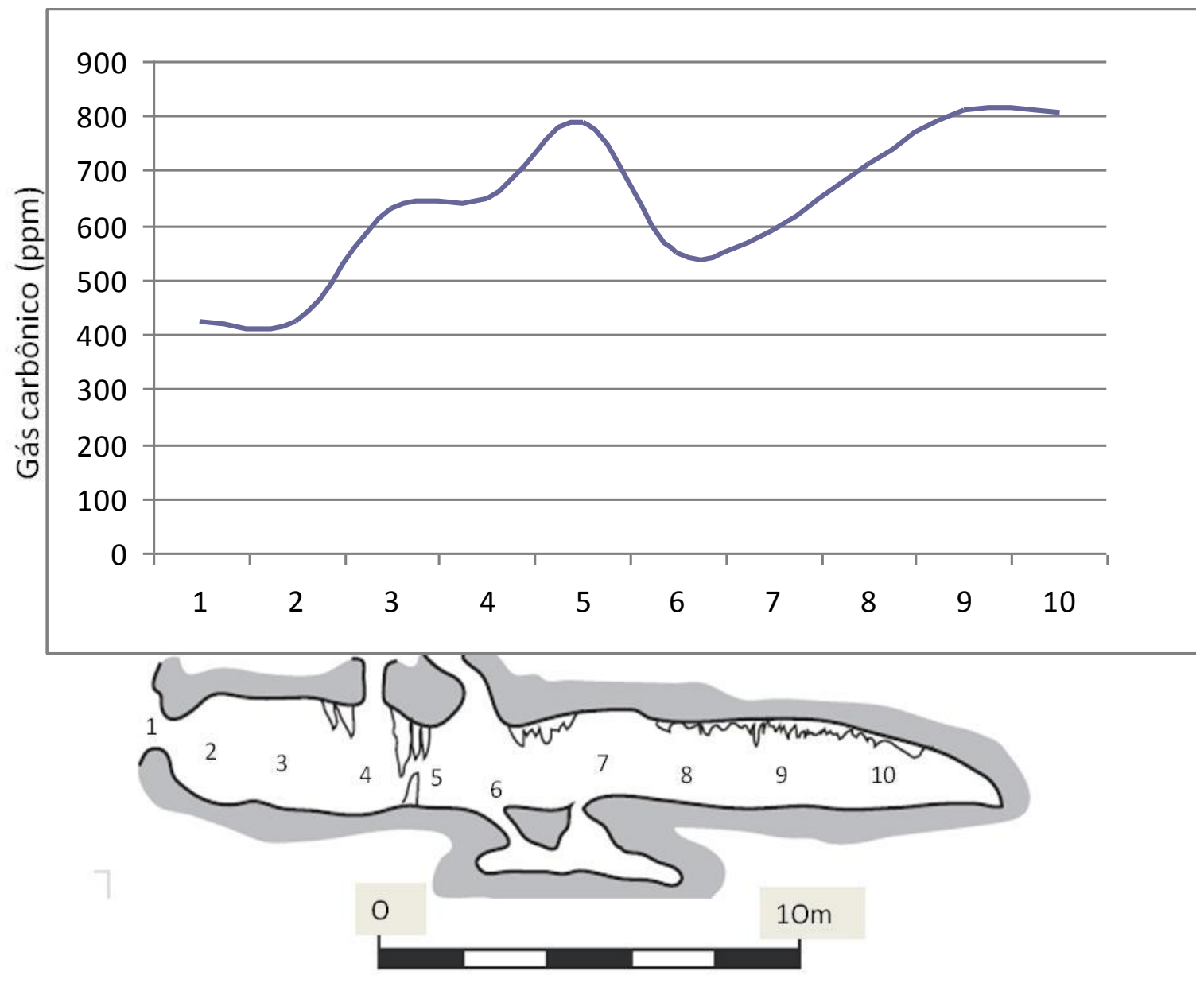

Figura 5.1.6: Perfil de gás carbônico atmosférico da Gruta do Cipó. Organização: Bárbara N. Rocha, 2010.

A quantidade de gás carbônico atmosférico aumenta na medida em que se adentra na caverna, chegando a um máximo de $810 \mathrm{ppm}$ no final da galeria, ante 425 ppm registrados na entrada. Essa tendência de aumento é rompida no meio da galeria devido à presença de claraboias que permitem uma maior ventilação nesse ponto. 
A elevada concentração de $\mathrm{CO}_{2}$ no ambiente subterrâneo explica-se pela dinâmica de formação dos espeleotemas, cujo processo químico resulta na liberação do gás. Outros fatores, como a fisiologia da gruta, a produção de organismos oxidantes e materiais orgânicos presentes no substrato também contribuem para o aumento da concentração de gás carbônico, como descrito por Palomba (1995).

\section{2 - Gruta do Fogo}

A Gruta do Fogo apresenta extensão inferior a 130m, constituindo-se por uma parte seca e outra molhada, por onde corre um rio estreito e de águas calmas. Não apresenta claraboias, sendo seu interior totalmente afótico.

Os pontos de monitoramento de temperatura e umidade relativa do ar podem ser visualizados na figura 5.2.1.

O primeiro termohigrômetro (foto superior à esquerda) foi instalado na entrada da caverna, caracterizando o microclima transicional. Neste ponto, incide radiação solar difusa, devido à densa cobertura vegetal do meio externo. O segundo foi alocado no meio de um corredor seco onde há circulação de pessoas. O terceiro ficou no final da galeria seca, próximo ao acesso à galeria do rio, porém fora do caminhamento turístico.

Problemas com a estação meteorológica impediram a comparação dos dados da caverna com os do meio externo. 


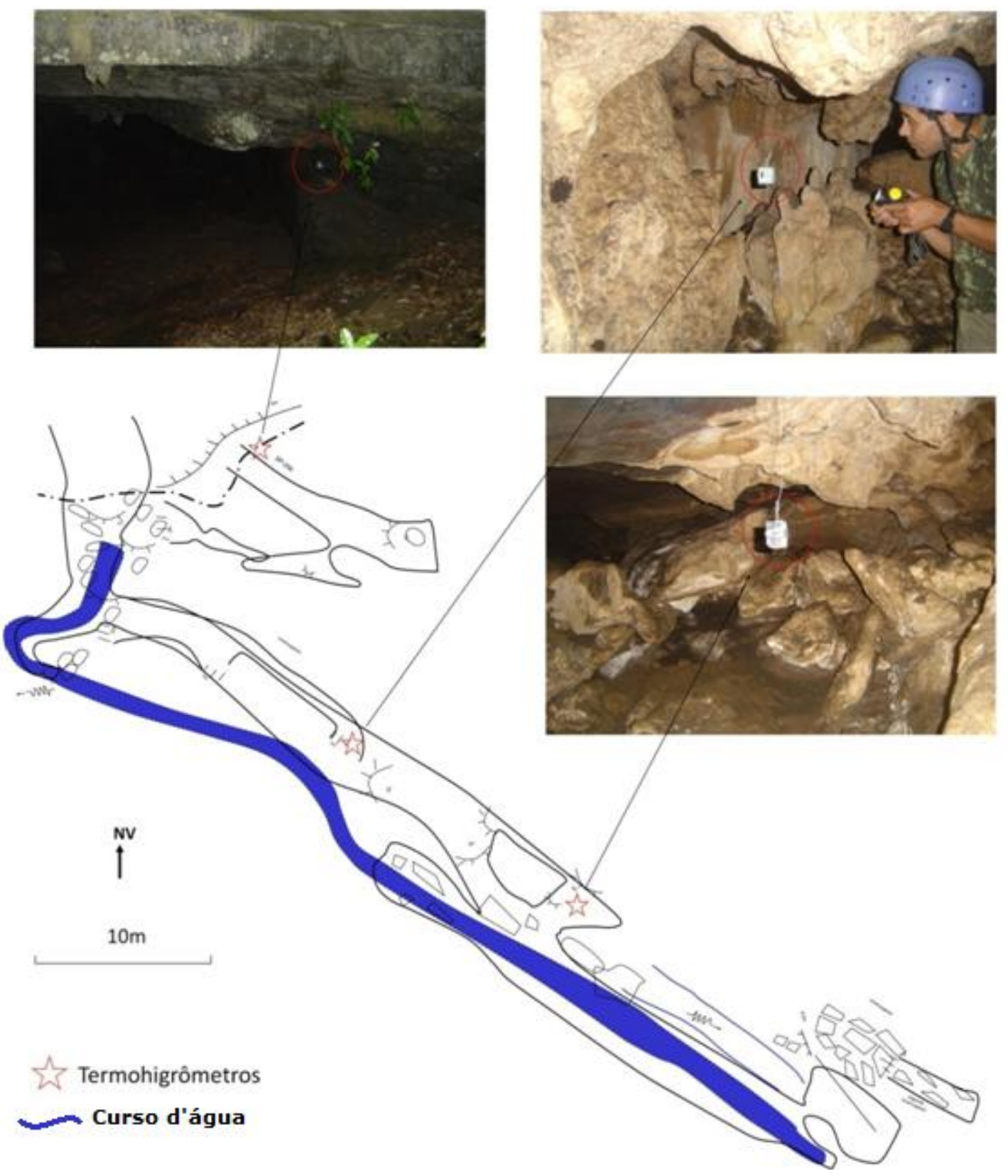

Figura 5.2.1: Localização dos termohigrômetros na Gruta do Fogo. Organização e fotografias: Bárbara N. Rocha, 2010. Fonte: Instituto EKOS, 2009.

A tabela a seguir apresenta alguns parâmetros estatísticos dos dados de temperatura e umidade relativa do ar obtidos nos três pontos de coleta, no período de 6 a 13 de fevereiro de 2009. 
Tabela 5.2.1: Parâmetros estatísticos da temperatura e umidade relativa do ar da Gruta do Fogo (período de 6 a 13/02/2009).

\begin{tabular}{|l|ccc|ccc|}
\cline { 2 - 7 } & \multicolumn{3}{c|}{ Temperatura do ar $\left({ }^{\circ} \mathrm{C}\right)$} & \multicolumn{3}{c|}{ Umidade relativa do ar (\%) } \\
\cline { 2 - 7 } & Entrada & $\begin{array}{c}\text { Salão } \\
\text { visitável }\end{array}$ & $\begin{array}{c}\text { Salão não } \\
\text { visitável }\end{array}$ & Entrada & $\begin{array}{c}\text { Salão } \\
\text { visitável }\end{array}$ & $\begin{array}{c}\text { Salão não } \\
\text { visitável }\end{array}$ \\
\hline \hline média & 19,1 & 17,2 & 16,8 & 100,0 & 100,0 & 99,3 \\
máximo & 20,4 & 17,5 & 17,1 & 100,0 & 100,0 & 100,0 \\
mínimo & 17,3 & 17,2 & 16,8 & 96,1 & 100,0 & 70,8 \\
amplitude & 3,1 & 0,3 & 0,3 & 3,9 & 0,0 & 29,2 \\
moda & 19,3 & 17,2 & 16,8 & 100,0 & 100,0 & 100,0 \\
desvio padrão & 0,6 & 0,0 & 0,1 & 0,2 & 0,0 & 3,7 \\
variância & 0,4 & 0,0 & 0,0 & 0,0 & 0,0 & 13,5 \\
\hline
\end{tabular}

Organização: Bárbara N. Rocha, 2010.

A média de temperatura mais elevada do período $\left(19,1^{\circ} \mathrm{C}\right)$ ocorreu na entrada da caverna, onde há incidência de radiação solar direta e difusa. $\mathrm{Na}$ medida em que se adentra na cavidade, as médias térmicas diminuem, atingindo o valor mais baixo na área não visitável $\left(16,8^{\circ} \mathrm{C}\right)$.

O máximo valor foi registrado na entrada da caverna, sendo de $20,4^{\circ} \mathrm{C}$. Já os mínimos foram encontrados no meio interno, sendo de $16,8^{\circ} \mathrm{C}$ no salão não visitável e $17,2^{\circ} \mathrm{C}$ no visitável. A amplitude térmica do meio externo foi superior a $3^{\circ} \mathrm{C}$ e no meio interno foi igual a $0,3^{\circ} \mathrm{C}$.

As modas das amostras de temperatura foram iguais à média no interior da gruta. Essa estabilidade do ambiente também pode ser comprovada pela baixa variância e desvio padrão.

A umidade relativa do ar média foi de $100 \%$ na entrada e no salão visitável e superior a $99 \%$ no último ponto. Os máximos registrados foram sempre de $100 \%$, enquanto o mínimo chegou a $70,8 \%$ no salão não visitável. Essa elevada amplitude neste ponto contribuiu para uma variância significativa da amostra $(14,3)$ e, consequentemente, para um alto desvio padrão.

A moda das amostras resultou em valores de $100 \%$ em todos os pontos, confirmando a predominância de situações com saturação atmosférica em ambientes cavernícolas.

As estatísticas de temperatura e umidade relativa do ar da gruta do Fogo se assemelharam às da gruta do Cipó. A umidade relativa mostrou-se 
elevada e a temperatura apresentou amplitudes menores na medida em que se interioriza nas cavidades.

A figura 5.2.2 mostra a variação da temperatura do ar nos três locais de coleta de dados, durante o período de uma semana.

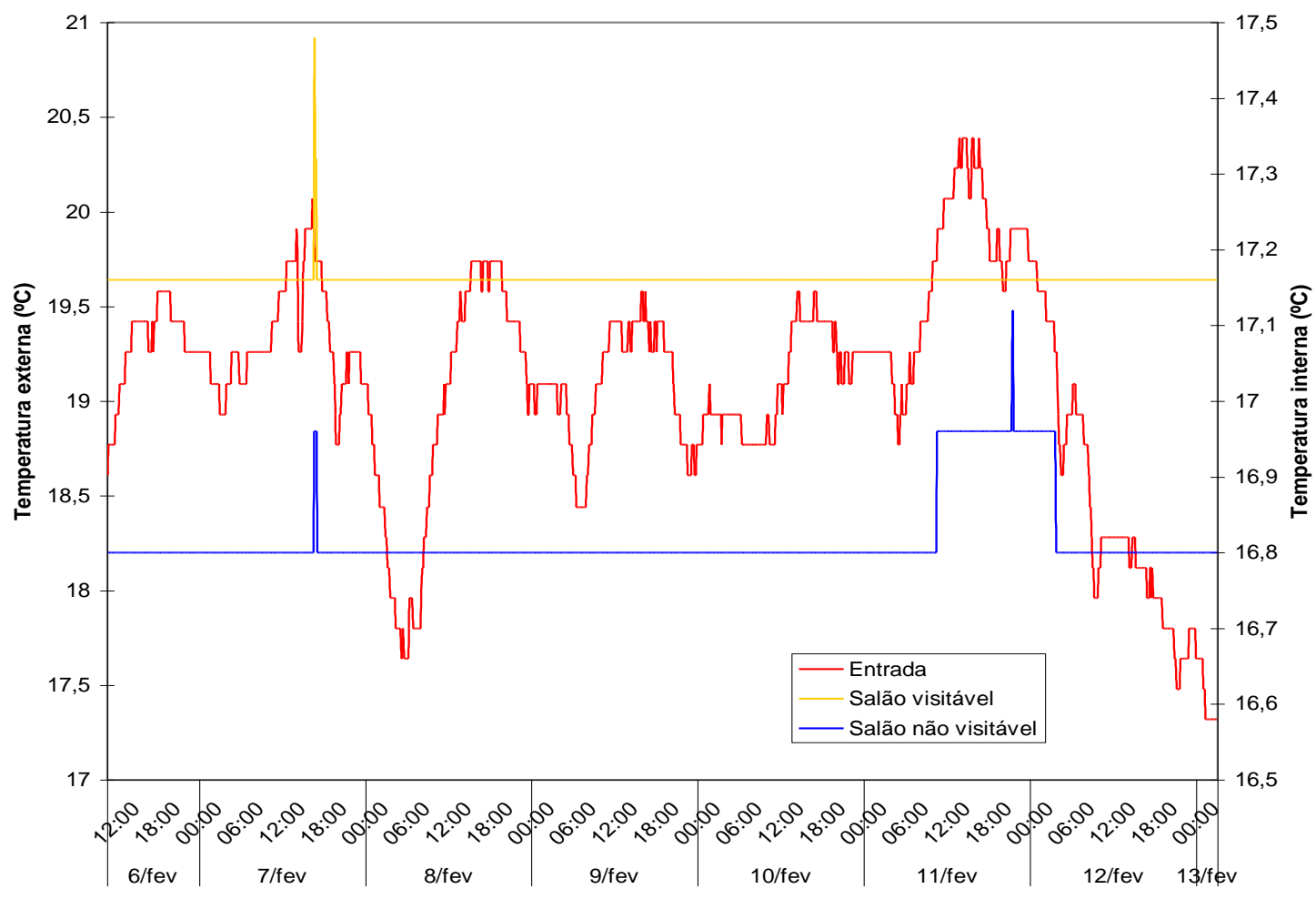

Figura 5.2.2: Variação da temperatura do ar $\left({ }^{\circ} \mathrm{C}\right)$ na Gruta do Fogo.

Organização: Bárbara N. Rocha, 2010.

Na entrada da caverna, a temperatura do ar apresentou elevada amplitude, acompanhando as flutuações ambientais do meio externo (alternância entre dia e noite). Já no interior da cavidade a temperatura permaneceu constante em $17,2^{\circ} \mathrm{C}$ no salão visitável e em $16,8^{\circ} \mathrm{C}$ na área sem visitação durante praticamente todo o tempo. Nota-se uma pequena variação apenas nos dias 7 e 11/02.

A alteração ocorrida no dia 7 pode ser explicada pela presença de cinco visitantes, que estiveram na gruta das 16h20min às 16h40min. Detalhando-se a figura anterior, percebe-se que o aumento da temperatura nesse dia ocorreu exatamente no momento em que os visitantes estiveram na cavidade (figura 5.2.3). O aumento chegou a $0,3^{\circ} \mathrm{C}$ e $0,2^{\circ} \mathrm{C}$ no salão visitável e não visitável, respectivamente. Após a saída do grupo, a gruta 
demorou cerca de 20 minutos para retornar sua condição anterior, de estabilidade.

Nota-se também variações na temperatura nos dias 11 e 12, somente no salão não visitável. Este, por estar próximo ao leito do rio, pode apresentar maior fluxo de energia. A hipótese é de que o rio poderia imprimir uma maior ventilação, devido ao fluxo de suas águas, além de apresentar temperatura diferente da atmosférica, promovendo uma variação da temperatura do ar neste ponto.

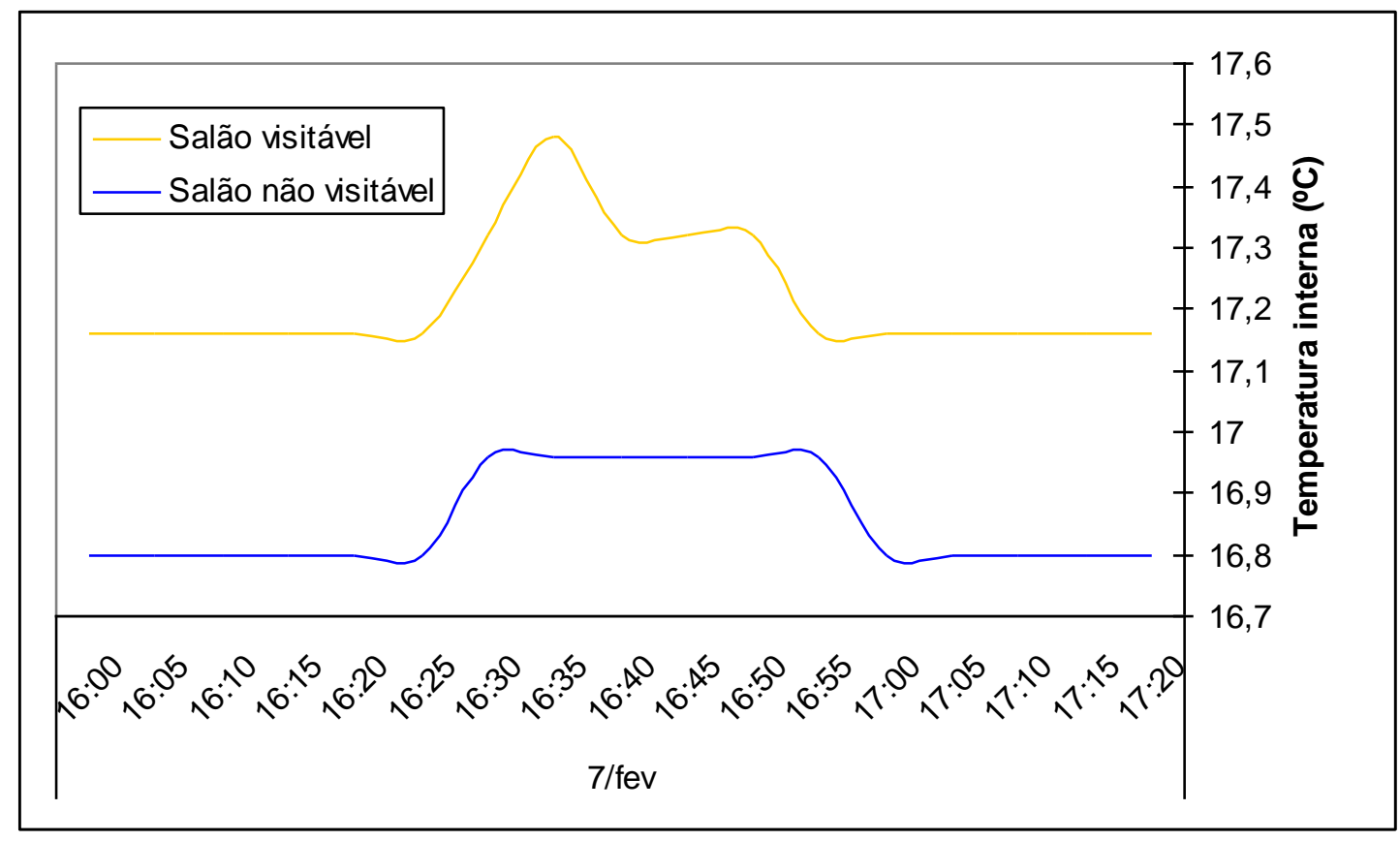

Figura 5.2.3: Variação da temperatura do $\operatorname{ar}\left({ }^{\circ} \mathrm{C}\right)$ interna da Gruta do Fogo no dia 7 de fevereiro a cada 5 minutos.

Organização: Bárbara N. Rocha, 2010.

Analisando-se a próxima figura (figura 5.2.4), o ar apresentou-se saturado durante a maior parte do período analisado. A elevada umidade do ar decorre da proteção pelo capeamento rochoso, da presença de um curso d'água no interior da gruta e do gotejamento dos espeleotemas. 


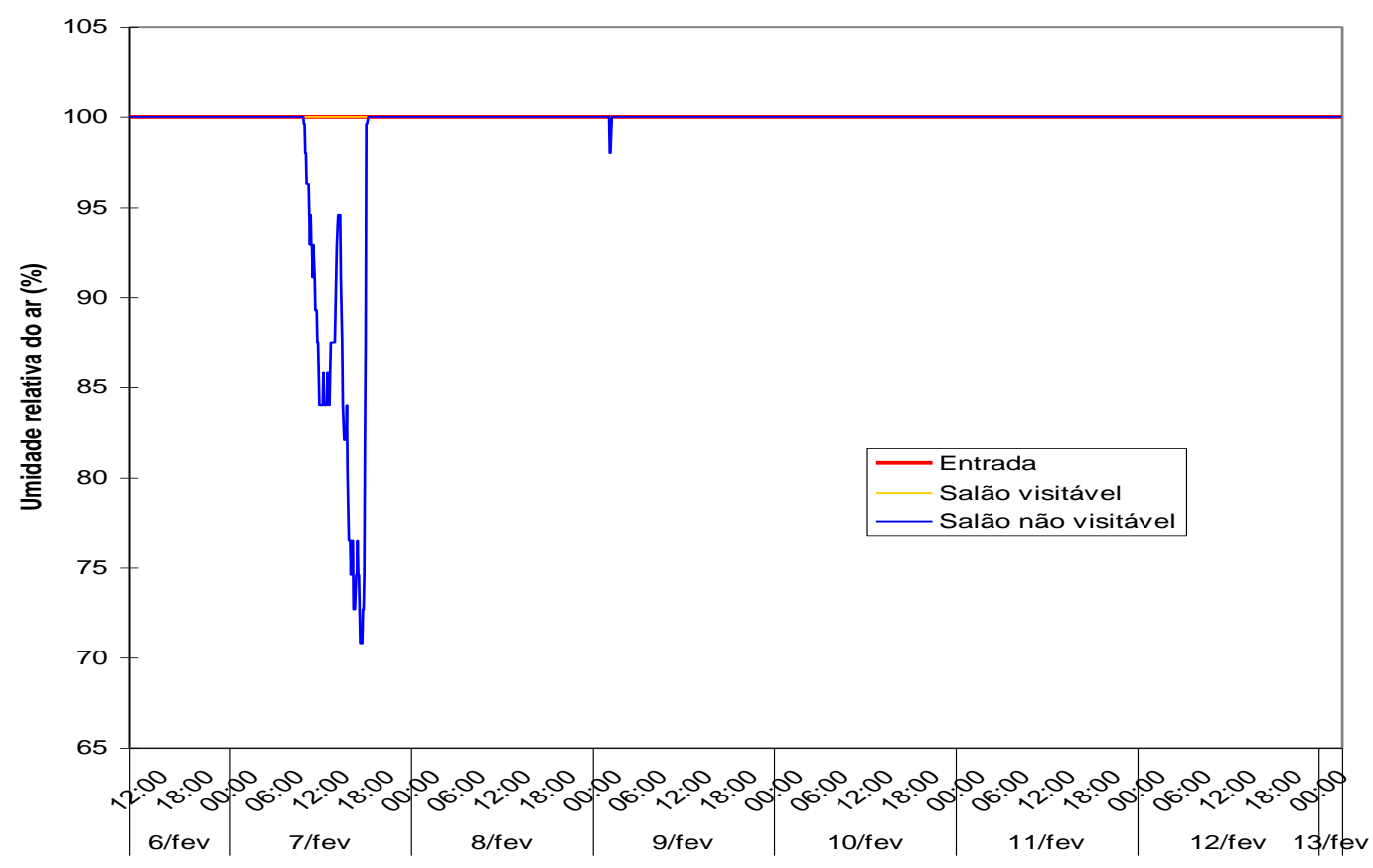

Figura 5.2.4: Variação da umidade relativa do ar (\%) na Gruta do Fogo. Organização: Bárbara N. Rocha, 2010.

$\mathrm{Na}$ entrada da gruta e no salão visitável a umidade relativa do ar permaneceu constante em 100\% durante todo o período de análises, enquanto no não visitável a UR variou bastante no dia 7 chegando a um mínimo de 70,8\%. Esta variação pode ser decorrente do maior fluxo de energia existente neste ponto, com possibilidade de ter sido acentuada pela visitação, visto que o mínimo foi registrado às $17 \mathrm{~h} 10 \mathrm{~min}$, pouco tempo após a saída dos turistas na caverna.

O perfil de gás carbônico da Gruta do Fogo, bem como os pontos de monitoramento, é apresentado Na figura 5.2.5.

As concentrações de $\mathrm{CO}_{2}$ permanecem praticamente constantes em 450 ppm no corredor de entrada da caverna, onde a ventilação é maior, com aumento significativo após a passagem para a galeria principal. Neste segundo corredor as taxas estiveram sempre próximas de 800 ppm. Essa elevação é resultado do distanciamento da boca da caverna, dificultando a circulação atmosférica e consequente dispersão do gás. Tal fato comprova que esta cavidade é mais suscetível a impactos em seu microclima decorrentes da visitação turística. 


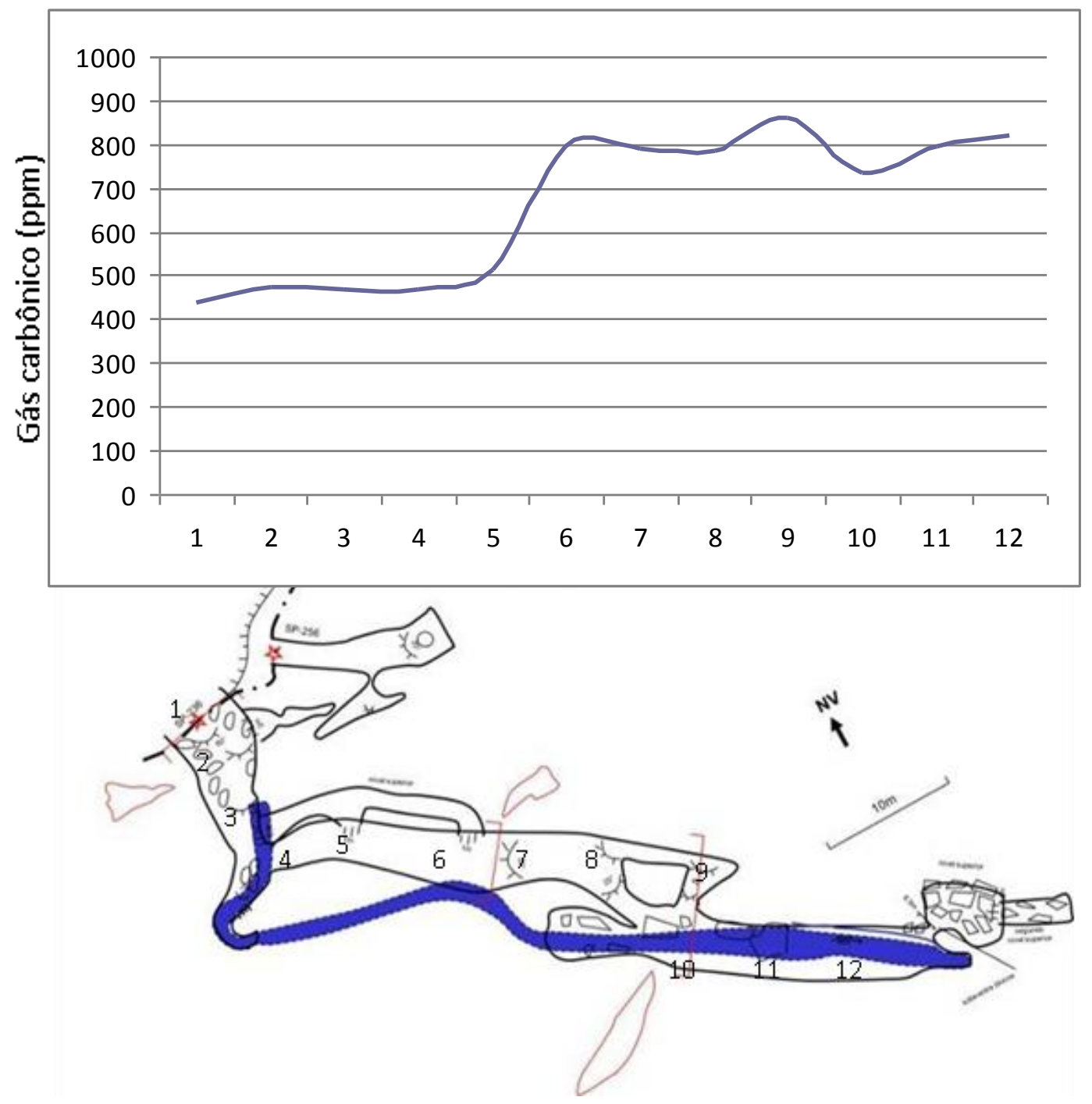

Figura 5.2.5: Perfil de gás carbônico atmosférico da Gruta do Fogo. Organização: Bárbara N. Rocha, 2010.

A análise do microclima da Gruta do Fogo mostrou que há alterações na atmosfera desta caverna decorrentes da visitação turística. Ressalta-se, no entanto, que as alterações na temperatura do ar apresentaram-se próximas ao erro instrumental dos termohigrômetros $\left(0,2^{\circ} \mathrm{C}\right)$ para um grupo máximo de cinco turistas e que a cavidade se recupera rápido termicamente. 


\section{3 - Toca dos meninos}

A Toca dos Meninos apresenta a menor extensão dentre as cavernas analisadas, com desenvolvimento de apenas 38m. É uma gruta seca, ou seja, sem cursos d'água e não apresenta zonas afóticas, devido ao tamanho reduzido e à presença de claraboias. Essa configuração permite uma boa ventilação na cavidade, fato que influencia diretamente em seu microclima.

A figura 5.3.1 contém o mapa da gruta com a localização e fotografia dos locais escolhidos para o monitoramento.
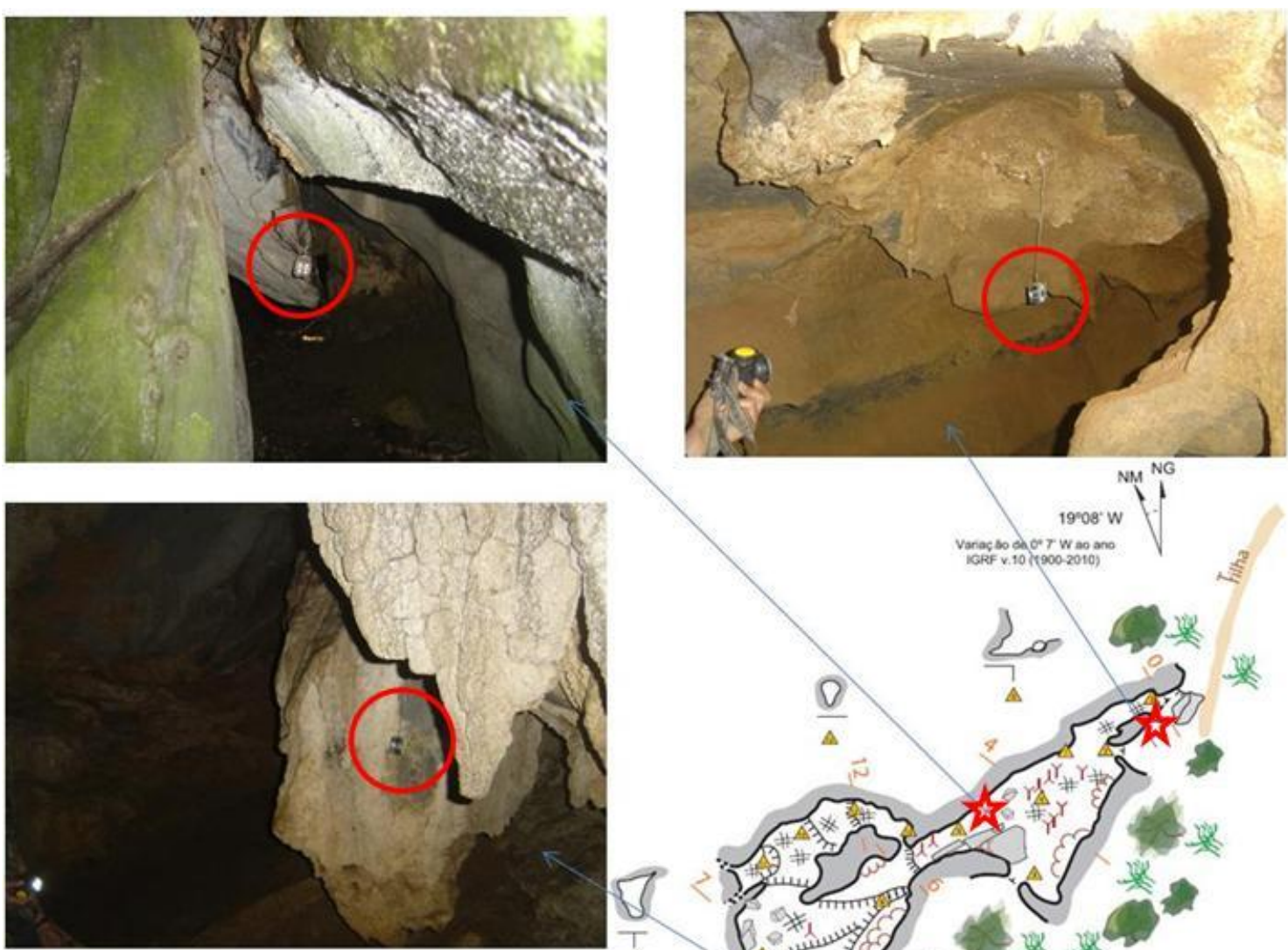

Termohigrômetros
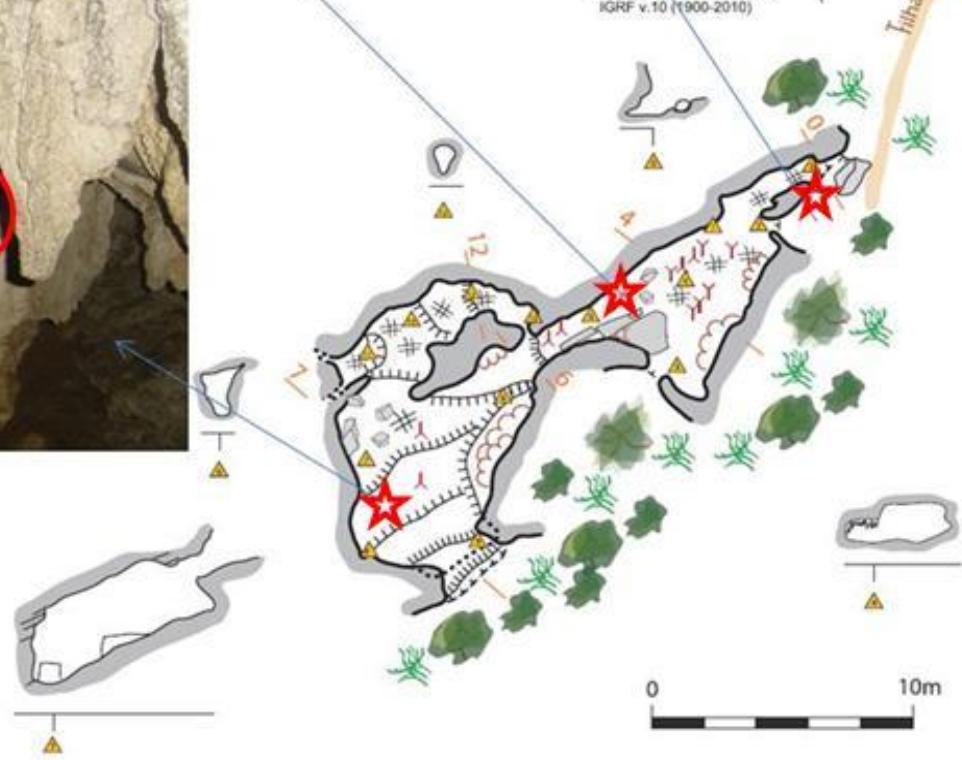

Figura 5.3.1: Localização dos termohigrômetros na Toca dos Meninos. Organização e fotografias: Bárbara N. Rocha, 2010. Fonte:Instituto EKOS, 2009.

Conforme definido na metodologia, o primeiro termohigrômetro teve que ser instalado na entrada da caverna para permitir a caracterização do microclima de transição entre os meios externo e interno. O segundo foi 
instalado em um local de passagem de turistas, no meio da galeria, e o último ficou no final do corredor. Em decorrência da configuração desta cavidade, constituída por um uma única galeria de pequena extensão, ela não contém trechos não visitáveis.

Os termohigrômetros foram instalados na Toca dos Meninos na manhã do dia 6 de fevereiro de 2009 e lá permaneceram até o dia 13 do mesmo mês. Os dados gerados foram trabalhados estatisticamente e podem ser visualizados na tabela a seguir.

Tabela 5.3.1: Parâmetros estatísticos da temperatura e umidade relativa do ar da Toca dos Meninos (período de 6 a 13/02/2009).

\begin{tabular}{|c|ccc|ccc|}
\cline { 2 - 7 } \multicolumn{1}{c|}{} & \multicolumn{3}{c|}{ Temperatura do $\operatorname{ar}\left({ }^{\circ} \mathrm{C}\right)$} & \multicolumn{3}{c|}{ Umidade Relativa do ar (\%) } \\
\cline { 2 - 7 } \multicolumn{1}{c|}{} & Entrada & $\begin{array}{c}\text { Salão } \\
\text { visitável }\end{array}$ & $\begin{array}{c}\text { Salão não } \\
\text { visitável }\end{array}$ & Entrada & $\begin{array}{c}\text { Salão } \\
\text { visitável }\end{array}$ & $\begin{array}{c}\text { Salão não } \\
\text { visitável }\end{array}$ \\
\hline média & 17,5 & 18,4 & 17,4 & 100,0 & 99,9 & 100,0 \\
máximo & 19,9 & 18,9 & 17,5 & 100,0 & 100,0 & 100,0 \\
mínimo & 16,2 & 18,0 & 17,3 & 100,0 & 62,9 & 0,0 \\
amplitude & 3,7 & 1,0 & 0,2 & 0,0 & 37,1 & 100,0 \\
moda & 17,4 & 18,4 & 17,3 & 100,0 & 100,0 & 100,0 \\
desvio padrão & 0,5 & 0,0 & 0,0 & 0,0 & 1,8 & 0,0 \\
variância & 0,7 & 0,2 & 0,1 & 0,0 & 1,3 & 0,0 \\
\hline
\end{tabular}

Organização: Bárbara N. Rocha, 2010.

A temperatura do ar mostrou-se mais elevada no meio da galeria, comparando aos demais pontos de análise, com média de $18,4^{\circ} \mathrm{C}$, ante $17,5^{\circ} \mathrm{C}$ da entrada e $17,4^{\circ} \mathrm{C}$ do final do corredor. As máximas e mínimas foram registradas na entrada $\left(19,9^{\circ} \mathrm{C}\right.$ e $16,2^{\circ} \mathrm{C}$, respectivamente).

As amplitudes térmicas foram maiores na entrada da gruta, com variações de $3,7^{\circ} \mathrm{C}$. No interior da cavidade, as variações térmicas do período foram iguais ou inferiores a $1^{\circ} \mathrm{C}$.

As modas das amostras são muito próximas das médias. Este fato, juntamente com o registro de baixas variâncias e desvios padrões, sugere uma estabilidade atmosférica nesta cavidade.

A umidade relativa do ar apresentou médias, máximos, mínimos e modas iguais a $100 \%$ na entrada da Toca e ao final dela. Consequentemente, as amplitudes, variâncias e desvios padrões nestes pontos foram nulas. 
A UR variou somente no meio da galeria; o mínimo chegou a $62,9 \%$, conferindo amplitude superior a 37\%. Apesar da variabilidade, a moda e a mediana estiveram em $100 \%$, comprovando que na atmosfera cavernícola o ar apresenta-se saturado na maior parte do tempo. A variância chegou a 1,8 , resultando em desvio padrão de 1,3 .

A figura 5.3.2 apresenta a variação da temperatura do ar na Toca dos Meninos durante o período estabelecido de uma semana. Devido aos problemas com a estação meteorológica, não há dados do meio externo para serem comparados neste período.

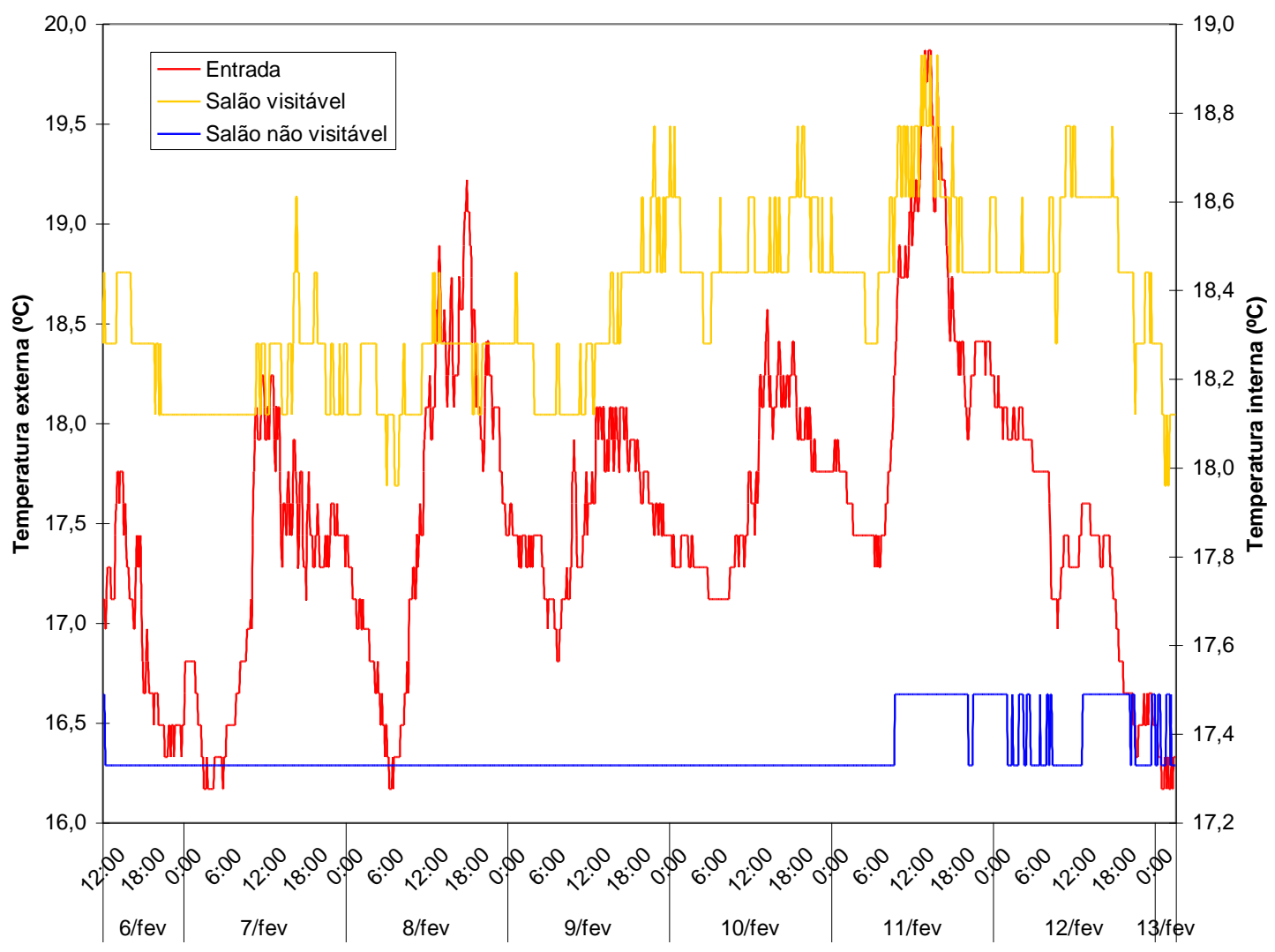

Figura 5.3.2: Variação da temperatura do ar ( $\left.{ }^{\circ} \mathrm{C}\right)$ na Toca dos Meninos. Organização: Bárbara N. Rocha, 2010.

Os dados de temperatura do ar no ponto situado na entrada da gruta apresentaram as mais elevadas oscilações diárias, apresentando ciclo diuturno que responde a variação da radiação solar, pois neste ponto há incidência de radiação difusa. No meio da galeria (salão visitável), a temperatura também se mostrou variável, acompanhando suavemente as variações externas, porém com amplitudes térmicas bastante reduzidas e atraso na assimilação do tempo exterior. Ao final da galeria (salão não 
visitável), a atmosfera cavernícola tende a estabilidade, com variação diária inferior a $0,3^{\circ} \mathrm{C}$.

A Toca dos Meninos é pouco procurada por turistas. Assim, uma visitação teve que ser simulada no dia 7/02 com cinco pessoas para analisar as possíveis alterações microclimáticas desse ambiente.

$\mathrm{Na}$ presença de visitantes, a temperatura do ponto mais interior da caverna permaneceu constante em $17,3^{\circ}$, fato que demonstra ausência de impactos na atmosfera dessa gruta decorrentes do turismo.

A umidade relativa do ar pode ser analisada na figura 5.3.3.

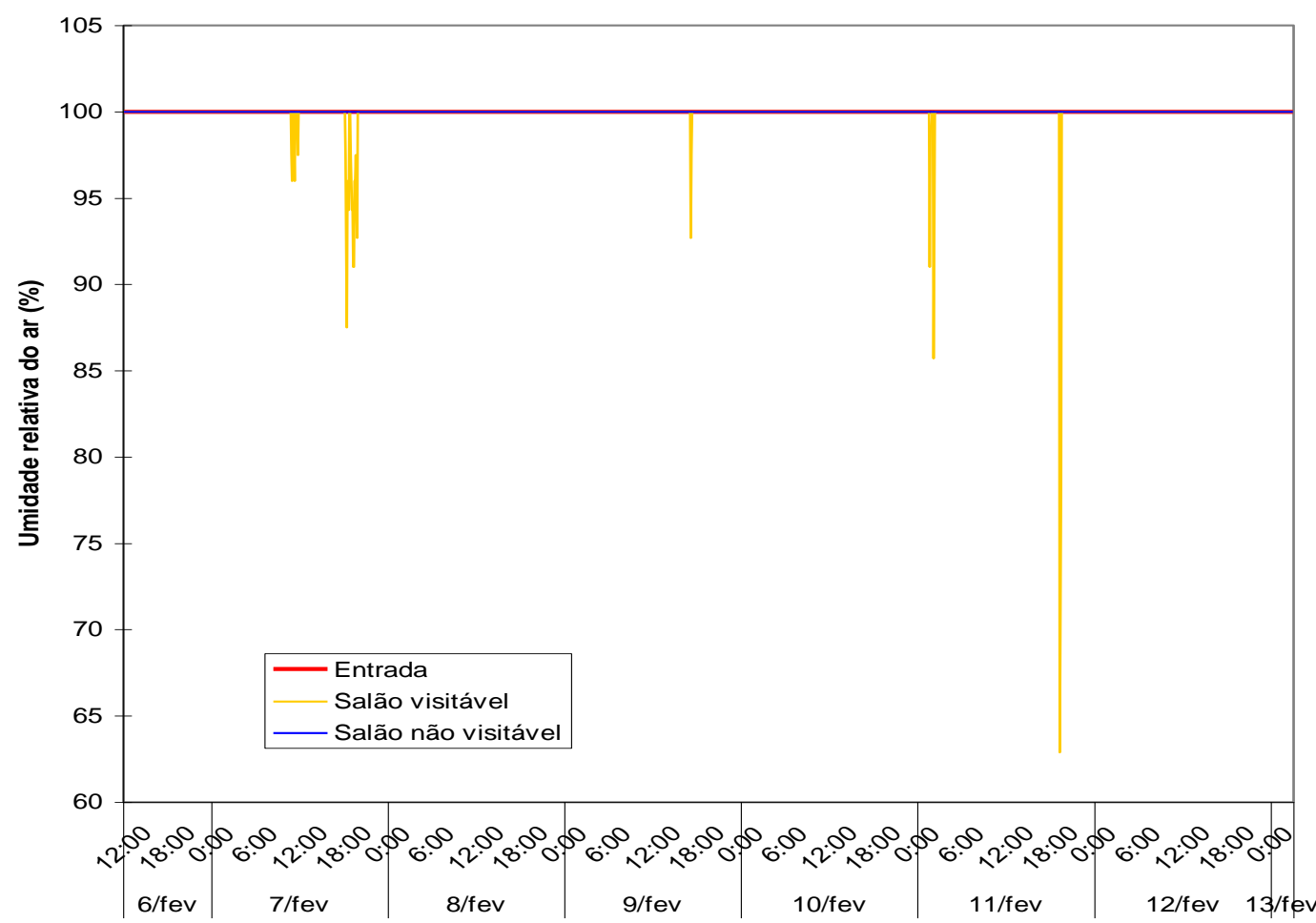

Figura 5.3.3: Variação da umidade relativa do ar $\left({ }^{\circ} \mathrm{C}\right)$ na Toca dos Meninos.

Organização: Bárbara N. Rocha, 2010.

A UR foi constante em 100\% na entrada da Toca dos Meninos e ao final dela. Variações podem ser percebidas no meio da galeria em três dias do período analisado, com mínimo de $62,9 \%$ no dia $11 / 02$. Como as variações são frequentes, não podemos relacioná-las ao turismo. Essas variações decorrem da boa ventilação deste ponto, localizado próximo a claraboias e a entrada da gruta. 
A saturação nos outros dois pontos é decorrente do gotejamento dos espeleotemas, da proteção da caverna pelo recobrimento rochoso, pela presença de mata fechada no meio externo e pela realização do trabalho de campo em período chuvoso.

O perfil de gás carbônico da Toca dos Meninos foi realizado na manhã do dia 13/02 e pode ser visto a seguir (figura 5.3.4). O perfil foi feito na presença de três pessoas.

As concentrações de $\mathrm{CO}_{2}$ variaram de 421 a 870 ppm, sendo menor na entrada da caverna e maior no final do corredor. Há uma leve queda nas concentrações em pontos próximos a claraboias, devido ao aumento da ventilação.

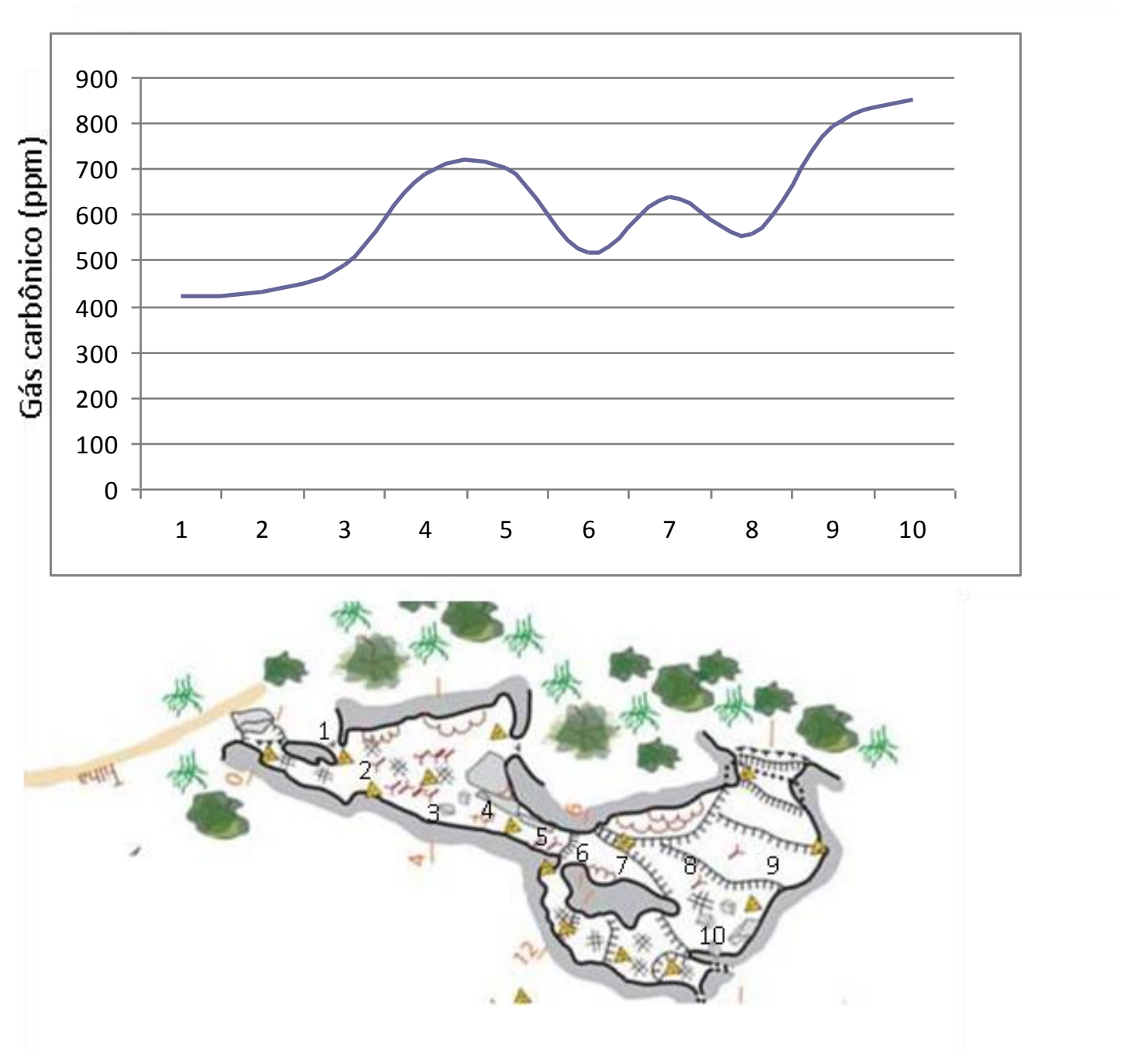

Figura 5.3.4: Perfil de gás carbônico da Toca dos Meninos.

Organização: Bárbara N. Rocha, 2010. 
Em suma, a Toca dos Meninos não apresenta alterações na temperatura e umidade relativa do ar em decorrência de visitações turísticas.

\section{4 - Gruta do Tatu}

A Gruta do Tatu apresenta pequenas dimensões (25m de desenvolvimento, apenas). Sua entrada é ampla e dela pode se seguir por duas galerias, uma a frente e outra à direita. Um rio estreito e raso segue para a galeria da direita, onde há também claraboias que facilitam a ventilação. Da galeria da frente é possível "enxergar" a atmosfera do meio externo, devido a sua proximidade com a entrada da gruta. Essas características imprimem grande troca energética na cavidade.

As fotos a seguir mostram os pontos de monitoramento microclimático da Gruta do Tatu. A falta de um mapa da caverna impediu a confecção de uma figura com a localização dos pontos de instalação dos termohigrômetros.
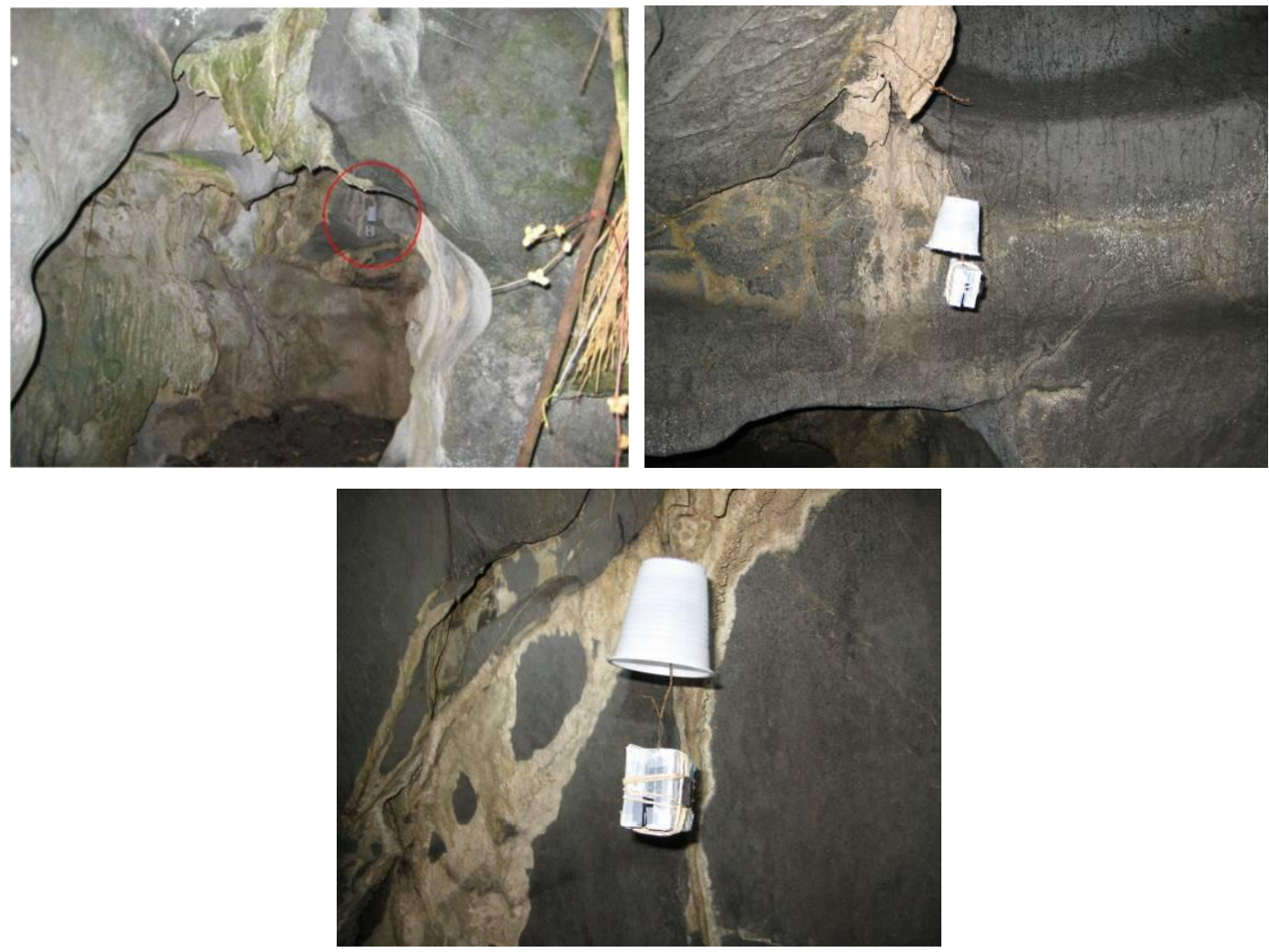

Figura 5.4.1: Foto dos termohigrômetros instalados na Gruta do Tatu. Organização e fotografias: Bárbara N. Rocha, 2010. 
O primeiro termohigrômetro (imagem superior à esquerda) foi instalado na entrada da caverna, caracterizando o microclima transicional. O segundo foi instalado no final do salão à direita, lado para onde os turistas se dirigem quando entram na caverna, próximo ao leito do rio e a claraboias (foto superior à direita). O último ficou no salão em frente da entrada, que é seco, ou seja, não drenado pelo rio, caracterizando a área sem visitação.

Os dados de temperatura e umidade foram coletados entre os dias 28 de fevereiro e 7 de março. A análise estatística deles (média, máximo, mínimo, amplitude, moda, mediana, variância e desvio padrão) pode ser visualizada na tabela a seguir.

Tabela 5.4.1: Parâmetros estatísticos da temperatura e umidade relativa do ar da Gruta do Tatu (período de 28/02 a 07/03/2009).

\begin{tabular}{|l|ccc|ccc|}
\cline { 2 - 7 } \multicolumn{1}{c|}{} & \multicolumn{3}{c|}{ Temperatura do ar $\left({ }^{\circ} \mathrm{C}\right)$} & \multicolumn{2}{c|}{ Umidade relativa do ar (\%) } \\
\cline { 2 - 7 } \multicolumn{1}{c|}{} & Entrada & $\begin{array}{c}\text { Salão } \\
\text { Visitável }\end{array}$ & $\begin{array}{c}\text { Salão não } \\
\text { Visitável }\end{array}$ & Entrada & $\begin{array}{c}\text { Salão } \\
\text { Visitável }\end{array}$ & $\begin{array}{c}\text { Salão não } \\
\text { Visitável }\end{array}$ \\
\hline Média & 20,8 & 19,6 & 19,7 & 100,0 & 100,0 & 100,0 \\
Mínimo & 22,7 & 20,9 & 20,7 & 100,0 & 100,0 & 100,0 \\
Amplitude & 19,1 & 17,6 & 18,0 & 100,0 & 100,0 & 100,0 \\
Moda & 3,6 & 3,3 & 2,7 & 0,0 & 0,0 & 0,0 \\
Variância & 20,7 & 19,4 & 20,1 & 100,0 & 100,0 & 100,0 \\
Desvio padrão & 0,7 & 0,4 & 0,3 & 0,0 & 0,0 & 0,0 \\
\hline
\end{tabular}

$\mathrm{Na}$ entrada da gruta, a média térmica foi de $20,8^{\circ} \mathrm{C}$. No interior da cavidade, as médias foram menores, sendo de $19,6^{\circ} \mathrm{C}$ no salão visitável e de $19,7^{\circ} \mathrm{C}$ na área sem visitação. O máximo valor registrado no período foi de $22,7^{\circ} \mathrm{C}$ na entrada da caverna e o mínimo, de $17,6^{\circ} \mathrm{C}$, foi registrado no salão com visitação.

A maior amplitude foi registrada na entrada da gruta, sendo de $3,6^{\circ} \mathrm{C}$. No meio interno, a amplitude foi de $3,3^{\circ} \mathrm{C}$ no salão à direita e de $2,7^{\circ} \mathrm{C}$ no salão frontal.

A moda das amostras apresentaram valores próximos a média em todos os pontos, apontado para uma estabilidade térmica do ambiente. Os baixos valores de variância e desvio padrão comprovam esse fato. 
$\mathrm{O}$ ar esteve saturado em todos os locais de coleta durante todo $\mathrm{O}$ período estudado. Assim, as médias, máximos, mínimos e modas foram sempre $100 \%$; já as amplitudes, variâncias e desvios padrões foram nulos.

A figura 5.4.2 apresenta a variação da temperatura do ar na Gruta do Tatu entre os dias 28 de fevereiro e 7 de março. No eixo da esquerda, estão as temperaturas do meio externo (estação meteorológica) e entrada da gruta, enquanto no eixo da direita podem ser visualizadas as temperaturas do meio interno (salões visitável e não visitável).

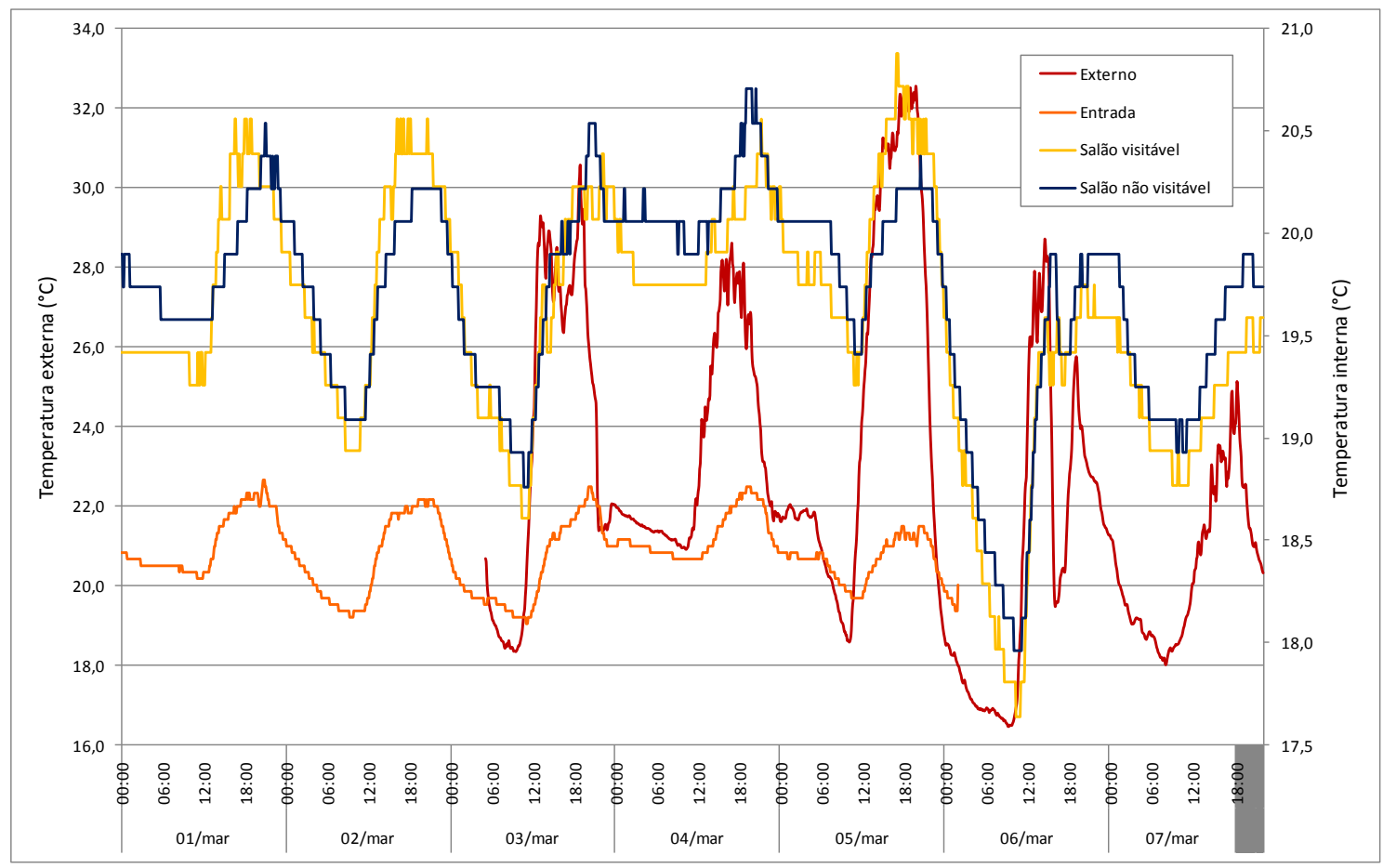

Figura 5.4.2: Variação da temperatura do $\operatorname{ar}\left({ }^{\circ} \mathrm{C}\right)$ na Gruta do Tatu. Organização: Bárbara N. Rocha, 2010.

O termógrafo instalado na entrada da cavidade apresentou problemas no dia 5 de março, o que inviabilizou o registro de dados a partir desse dia. Apesar disso, é possível perceber que as variações da temperatura do ar no meio interno acompanham o ciclo externo, com menor amplitude térmica, não sendo percebidos atrasos nas assimilações das condições atmosféricas exteriores. Essa caverna, portanto, não apresenta um microclima típico de ambiente subterrâneo, que é caracterizado pela estabilidade. 
O acompanhamento do ciclo diuturno da temperatura nessa caverna é possível devido à sua configuração, com boca ampla, claraboias e rio corrente, que facilitam a troca de energia com o meio externo.

A Gruta do Tatu foi visitada por 10 turistas no dia 7 de março. 0 primeiro grupo, composto por 4 integrantes visitou a caverna das 9h15min às 9h30min. Um segundo grupo, com 6 pessoas, esteve na cavidade das 17 às $17 \mathrm{~h} 10 \mathrm{~min}$. Apesar da ausência de registros na entrada da caverna neste dia, percebe-se que a temperatura no ambiente interno apresentou a mesma variação, seguindo a tendência de acompanhamento das variações externas e sem picos de alteração, o que permite inferir que não houve impacto na atmosfera da caverna em decorrência do turismo. Além disso, na presença dos seis turistas, a temperatura do ar apresentou queda.

A figura 5.4.3 mostra a variação da umidade relativa do ar da Gruta do Tatu.

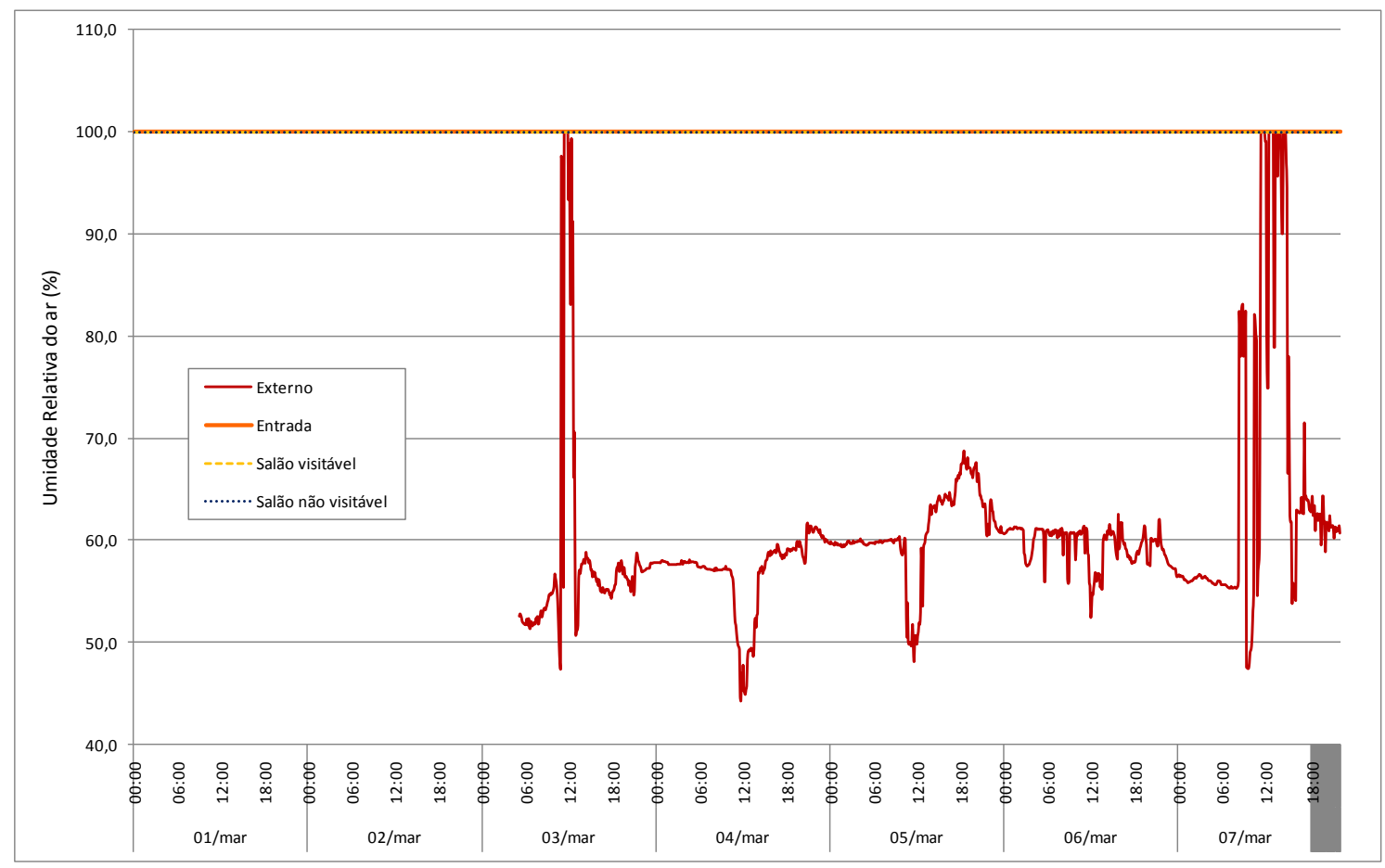

Figura 5.4.3: Variação da umidade relativa do ar (\%) na Gruta do Tatu. Organização: Bárbara N. Rocha, 2010.

A umidade na entrada e no interior da cavidade foi constante em 100\%, não apresentando variações no período. A UR da gruta não acompanha o ciclo externo que apresentou oscilação no período, devido aos 
dias de céu limpo, comprovado pela elevada radiação solar direta e ausência de chuvas registradas pela estação meteorológica.

A elevada umidade na atmosfera da gruta é decorrente da proteção pelo capeamento rochoso, da evapotranspiração da mata em seu entorno, da presença de um curso d'água em seu interior e do gotejamento dos espeleotemas.

A figura 5.4.4 apresenta o perfil de dióxido de carbono, realizado na manhã do dia 28 de fevereiro de 2009. A falta de um mapa da cavidade impede a visualização dos pontos do caminhamento. A entrada da caverna é representada pelo número 1 e o ponto mais interior é assinalado com o número 12.

Pela análise da figura, percebe-se que as concentrações de gás carbônico se elevam conforme se adentra na gruta, diminuindo próximo ao leito do rio, voltando a aumentar no final da galeria à direita.

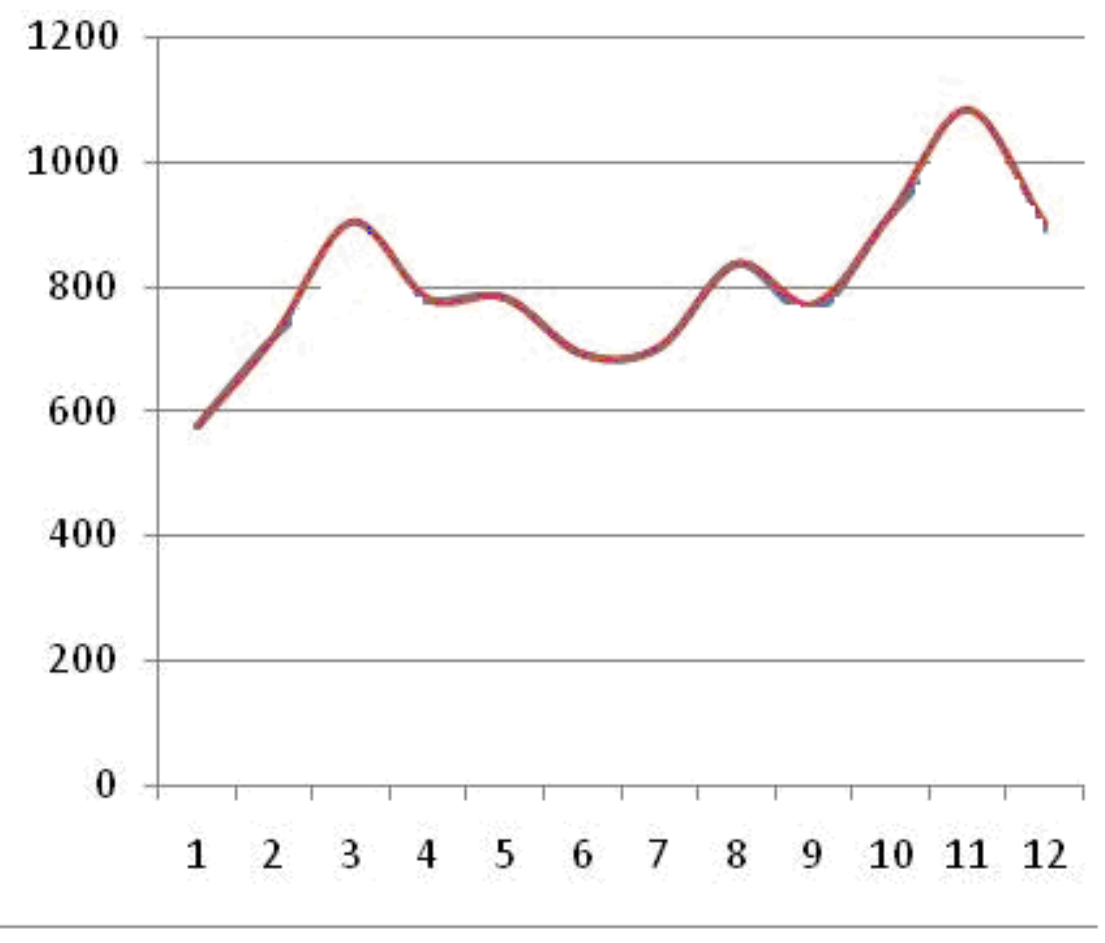

Figura 5.4.4: Perfil de gás carbônico atmosférico da Gruta do Tatu. Organização: Bárbara N. Rocha, 2010.

Pelo exposto, conclui-se que não ocorreu nenhuma alteração na atmosfera da Gruta do Tatu em decorrência da visitação turística. A presença de claraboias, que promovem maior ventilação e troca de energia 
com o meio externo, parece ser um fator determinante para que não haja estabilidade microclimática nesse sistema.

\section{5 - Gruta Jane Mansfield}

A Gruta Jane Mansfield apresenta extensão aproximada de 500m. Constitui-se de um único corredor, com poucas bifurcações, o que delimita um circuito único de visitação. Seu acesso se faz através de uma pequena ressurgência ativa de um dos tributários do rio Bocaina que corre por toda a caverna. Não há claraboias em seu interior.

Os trabalhos de campo para coleta de dados na Gruta Jane Mansfield foram realizados entre os dias 21 e 28 de fevereiro de 2009. As fotos a seguir mostram os pontos de monitoramento microclimático da Gruta Jane Mansfield (figura 5.5.1). A falta de um mapa da caverna impediu a confecção de uma figura com a localização dos pontos de instalação dos termohigrômetros.
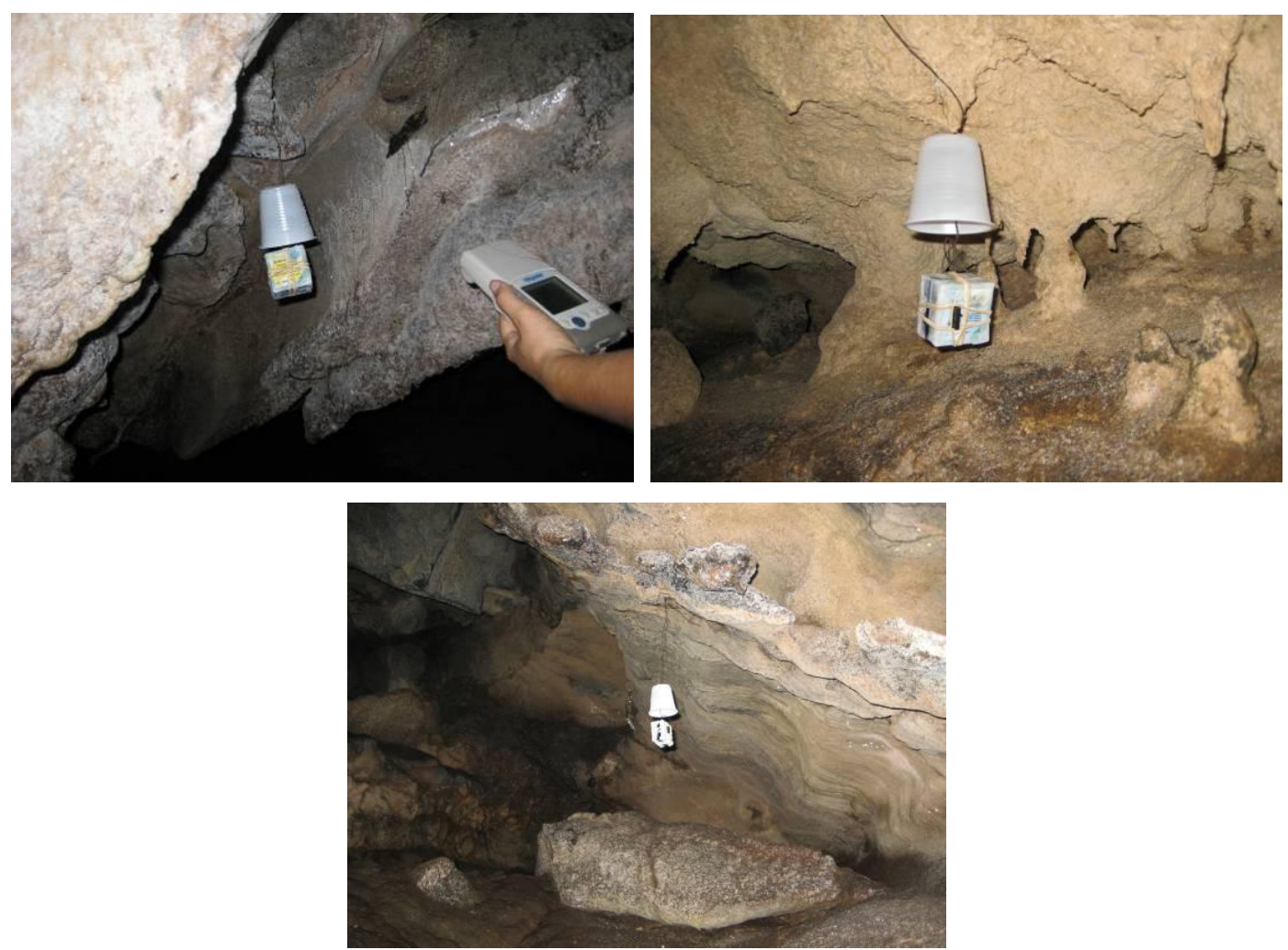

Figura 5.5.1: Foto dos termohigrômetros na Gruta Jane Mansfield. Organização e fotografias: Bárbara N. Rocha, 2010. 
O primeiro sensor (foto superior à esquerda) foi instalado na entrada da gruta, recebendo radiação solar difusa durante todo o dia. O segundo (imagem superior à direita) situou-se no final da galeria (zona afótica), local de grande visitação. O último termohigrômetro (foto inferior) foi alocado em uma área fora do circuito tradicional de visitação, no acesso a uma galeria superior na parte central da gruta. Neste ponto há uma bica de água.

A tabela 5.5.1 apresenta parâmetros estatísticos da temperatura e umidade relativa do ar nos três locais estudados, durante o período de uma semana. Os parâmetros selecionados foram: média, máximo, mínimo, amplitude, moda, variância e desvio padrão.

Tabela 5.5.1: Parâmetros estatísticos da temperatura e umidade relativa do ar da Gruta Jane Mansfield (período de 21 a 28/02/2009).

\begin{tabular}{|l|ccc|ccc|}
\cline { 2 - 6 } \multicolumn{1}{c|}{} & \multicolumn{3}{c|}{ Temperatura do ar $\left({ }^{\circ} \mathrm{C}\right)$} & \multicolumn{2}{c|}{ Umidade relativa do ar (\%) } \\
\cline { 2 - 6 } \multicolumn{1}{c|}{} & Entrada & $\begin{array}{c}\text { Salão } \\
\text { Visitável }\end{array}$ & $\begin{array}{c}\text { Salão não } \\
\text { Visitável }\end{array}$ & Entrada & $\begin{array}{c}\text { Salão } \\
\text { Visitável }\end{array}$ & $\begin{array}{c}\text { Salão não } \\
\text { Visitável }\end{array}$ \\
\hline Média & 18,3 & 18,1 & 17,4 & 100,0 & 100,0 & 100,0 \\
Máximo & 19,8 & 18,3 & 17,6 & 100,0 & 100,0 & 100,0 \\
Mínimo & 17,8 & 18,0 & 17,2 & 100,0 & 100,0 & 100,0 \\
Amplitude & 2,0 & 0,3 & 0,4 & 0,0 & 0,0 & 0,0 \\
Moda & 18,0 & 18,1 & 17,5 & 100,0 & 100,0 & 100,0 \\
Variância & 0,4 & 0,1 & 0,1 & 0,0 & 0,0 & 0,0 \\
Desvio padrão & 0,2 & 0,0 & 0,0 & 0,0 & 0,0 & 0,0 \\
\hline
\end{tabular}

Organização: Bárbara N. Rocha, 2010.

Analisando-se os dados de temperatura, nota-se que a média semanal foi de $18,3^{\circ} \mathrm{C}$ na entrada da gruta, $18,1^{\circ} \mathrm{C}$ no salão visitável e $17,4^{\circ}$ na área sem visitação. A maior temperatura no primeiro ponto explica-se pela incidência de radiação solar difusa neste local; já a menor temperatura do último é decorrente do intenso fluxo de água do rio, que aumenta a ventilação neste ponto.

Os máximos valores do período acompanharam as médias, apresentando-se mais elevado na entrada $\left(19,8^{\circ} \mathrm{C}\right)$ e menor no salão não visitável $\left(17,6^{\circ} \mathrm{C}\right)$. Neste local foi detectado o mínimo do período, de $17,2^{\circ} \mathrm{C}$. Percebe-se uma pequena variação entre os máximos e mínimos, sendo a amplitude térmica igual ou inferior a $2^{\circ} \mathrm{C}$ em todos os locais 
pesquisados. A pequena amplitude resulta da elevada umidade da gruta, cortada por um rio de águas correntes em todo seu interior. A água é um elemento fundamental na manutenção do calor.

As modas encontram-se próximas das médias em todos os pontos, confirmando a estabilidade térmica da gruta.

A variabilidade das amostras foi pequena, resultando em um baixo desvio padrão (igual ou inferior a 0,2 em todos os pontos de coleta). Isso decorre da baixa amplitude térmica, que apontou uma grande estabilidade dos dados.

Durante todo período de análise e em todos os pontos de registros, 0 ar apresentou-se saturado. Assim os parâmetros média, máximo, mínimo e moda foram sempre de $100 \%$ e a amplitude, variância e desvio padrão da umidade relativa do ar foram nulas.

A saturação decorre, dentre outros fatores, da presença de um rio caudaloso, com algumas quedas d'água, fonte constante de umidade para a atmosfera.

O gráfico a seguir (figura 5.5.2) mostra a variação da temperatura do ar nos três pontos de monitoramento da gruta e no meio externo.

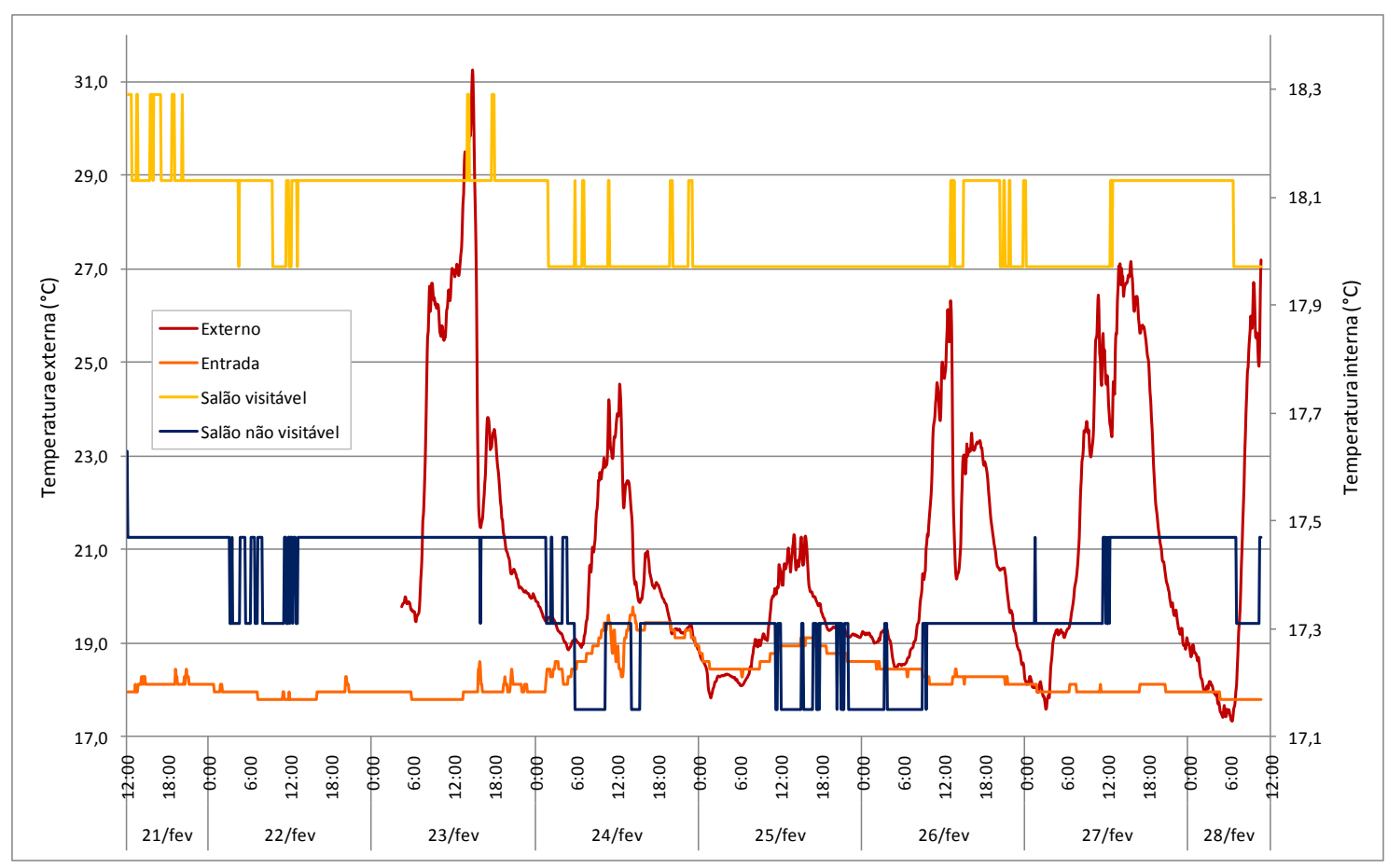

Figura 5.5.2: Variação da temperatura do ar ( $\left.{ }^{\circ} \mathrm{C}\right)$ na Gruta Jane Mansfield. Organização: Bárbara N. Rocha, 2010. 
$\mathrm{Na}$ entrada da gruta a temperatura apresenta variações que acompanham o ciclo diuturno, mas com amplitudes reduzidas e alguns atrasos na assimilação do tempo exterior. Nos dias 26 a 28 de fevereiro, as temperaturas deste ponto não acompanharam as elevações do meio externo. A presença de um rio de água corrente na entrada da gruta provém grande umidade para a atmosfera, impedindo grandes variações. As maiores oscilações na temperatura, neste ponto, ocorreram entre os dias 24 e $25 / 02$, chegando a um máximo de $19,8^{\circ} \mathrm{C}$.

$\mathrm{Na}$ área visitável, as temperaturas mantiveram-se praticamente constantes em $18^{\circ} \mathrm{C}$. A área não visitável apresentou as menores temperaturas, devido à sua localização, próxima ao leito do rio. O mínimo, de $17,2^{\circ} \mathrm{C}$, foi registrado nos dias 24,25 e 26 de fevereiro.

Durante o período de registros, a caverna foi visitada por cinco grupos de turistas. No dia 22, um grupo de três pessoas visitou a gruta das $10 \mathrm{~h} 00 \mathrm{~min}$ às $10 \mathrm{~h} 35 \mathrm{~min}$ e outro, com seis integrantes, das $10 \mathrm{~h} 45 \mathrm{~min}$ às $11 \mathrm{~h} 45 \mathrm{~min}$. Na manhã deste dia, os dois registradores internos marcavam as menores temperaturas diárias.

Um grupo de seis turistas visitou a caverna das $13 \mathrm{~h} 00 \mathrm{~min}$ às 14h20min no dia 23. Nenhuma alteração na temperatura foi detectada no salão não visitável. Já o salão visitável registrou um aumento de $0,1^{\circ} \mathrm{C}$, valor que está dentro do erro instrumental, que é de $0,2^{\circ} \mathrm{C}$, em um intervalo de dez minutos, das $14 \mathrm{~h} 00 \mathrm{~min}$ às $14 \mathrm{~h} 10 \mathrm{~min}$. Alterações dessa magnitude também ocorreram em dias e períodos sem visitação não comprovando a ocorrência de impacto antrópico.

Outras oito pessoas visitaram a gruta nas manhãs dos dias 24 e 27. No momento das visitações, nenhuma alteração nas curvas de temperatura foram encontradas.

A figura 5.5.3 apresenta a variação da umidade relativa do ar. A UR da caverna não variou durante o período, apresentando-se em 100\% em todos os pontos, graças à presença constante de água na galeria, devido à presença de um rio, pelo gotejamento dos espeleotemas e pela proteção do recobrimento rochoso.

Mesmo na entrada da caverna, as variações da umidade relativa do ar no meio externo não puderam ser percebidas. 


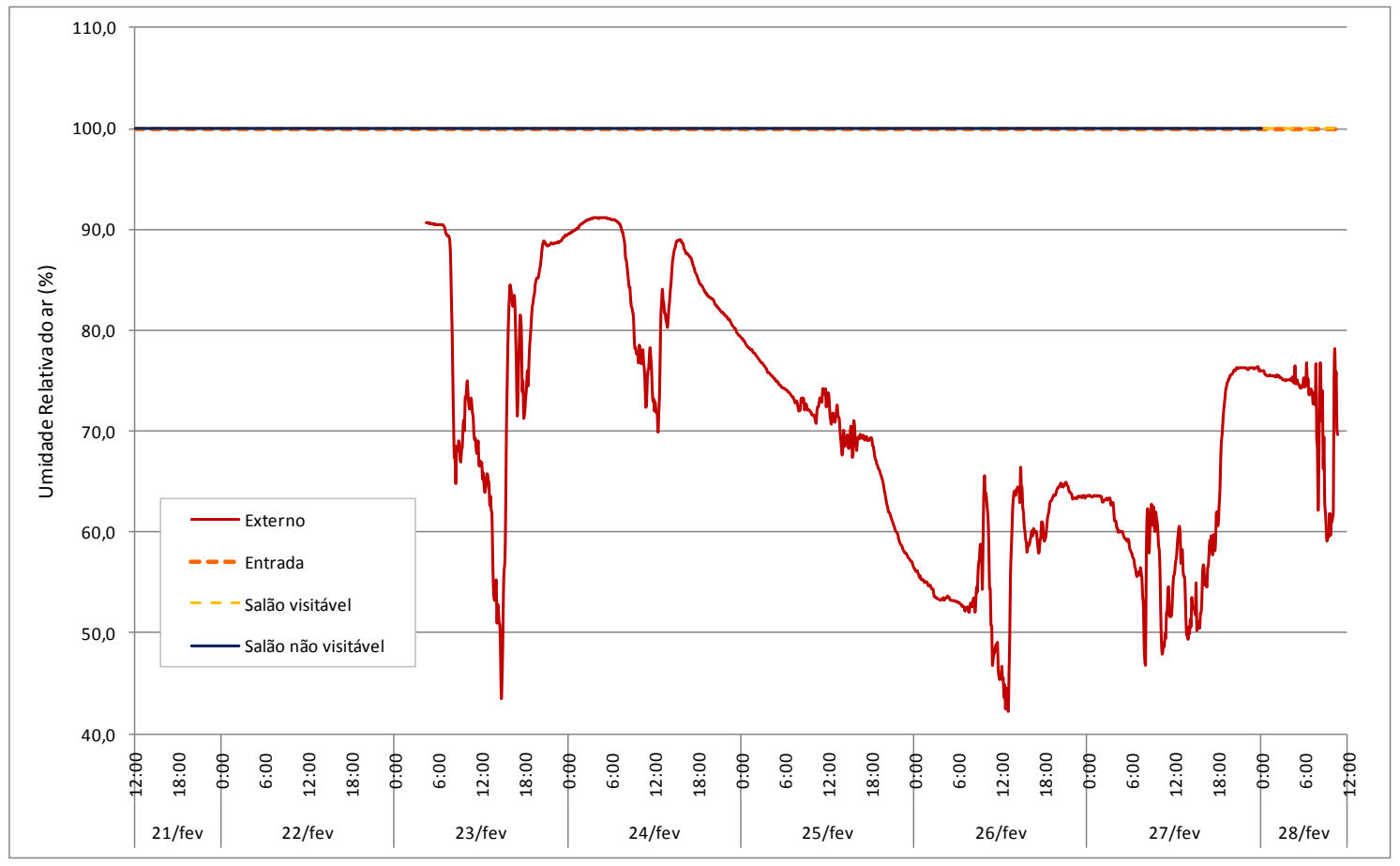

Figura 5.5.3: Variação da umidade relativa do ar (\%) na Gruta Jane Mansfield.

Organização: Bárbara N. Rocha, 2010.

A figura 5.5.4 apresenta o perfil de gás carbônico da Gruta Jane Mansfield, realizado na manhã do dia 28 de fevereiro. Foram coletados dados em 15 pontos da caverna, da entrada (ponto 1) ao final da galeria (ponto 15).

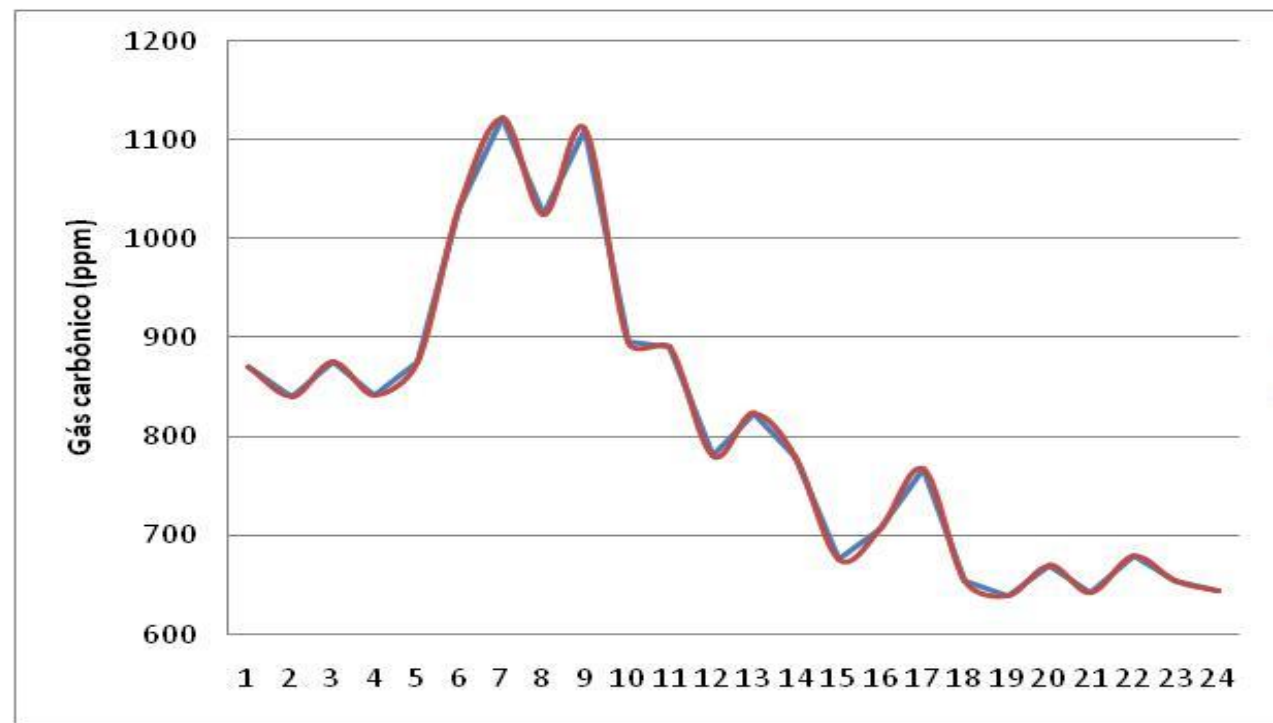

Figura 5.5.6: Perfil de gás carbônico atmosférico da Gruta Jane Mansfield. Organização: Bárbara N. Rocha, 2010. 
$\mathrm{Na}$ entrada da gruta (ponto 1) a concentração de gás carbônico estava em 870 ppm. Após a passagem por um corredor estreito que dá acesso a caverrna, a taxa de $\mathrm{CO}_{2}$ eleva-se significativamente, atingindo 1122 ppm no primeiro salão (ponto 7). Depois, a concentração do gás diminui lentamente, até atingir $645 \mathrm{ppm}$ no final da cavidade (ponto 24). Empiricamente, pode-se perceber uma maior ventilação a partir do ponto 7, pois o rio torna-se mais caudaloso e apresenta pequenas quedas d'água.

Conclui-se, através da metodologia adotada, que Gruta Jane Mansfield não apresenta alterações em sua atmosfera (temperatura, umidade relativa do ar e gás carbônico) em períodos com visitação turística.

\section{6 - Gruta do Fendão}

A Gruta do Fendão é uma das maiores do Parque Estadual de Intervales, apresentando mais de um quilômetro de extensão. É uma caverna molhada, constituída pela galeria do rio que cruza todo seu interior. Apresenta duas entradas e diversas claraboias, além de teto alto e salões amplos, permitindo grande troca de energia com o meio externo. O fluxo intenso da água do rio, aliado a seu grande volume, também facilita essa troca.

Todo caminhamento turístico é feito no leito do rio. Em épocas de cheia, um turista de altitude média pode molhar o corpo até a altura do peito.

A figura 5.6.1 apresenta o mapa da caverna, as fotos dos pontos de monitoramento e o local de instalação dos termohigrômetros.

O trabalho de campo para a coleta dos dados da Gruta do Fendão realizou-se entre os dias 28 de fevereiro e 7 de março de 2009. O primeiro termohigrômetro (foto à direita) foi instalado em uma das entradas da caverna, na ressurgência do rio. Este local apresenta um paredão rochoso que o protege da luminosidade proveniente do sol, permitindo somente a passagem de radiação solar difusa em alguns momentos do dia.

O segundo registrador foi alocado no meio da cavidade, em um salão mais amplo, onde os turistas param para fazer um blackout. Este local 
apresenta, além do leito do rio, uma parte seca. Perto deste ponto, há uma entrada que dá acesso a uma pequena galeria superior. Este local foi escolhido para instalação do terceiro termohigrômetro (foto superior à esquerda).

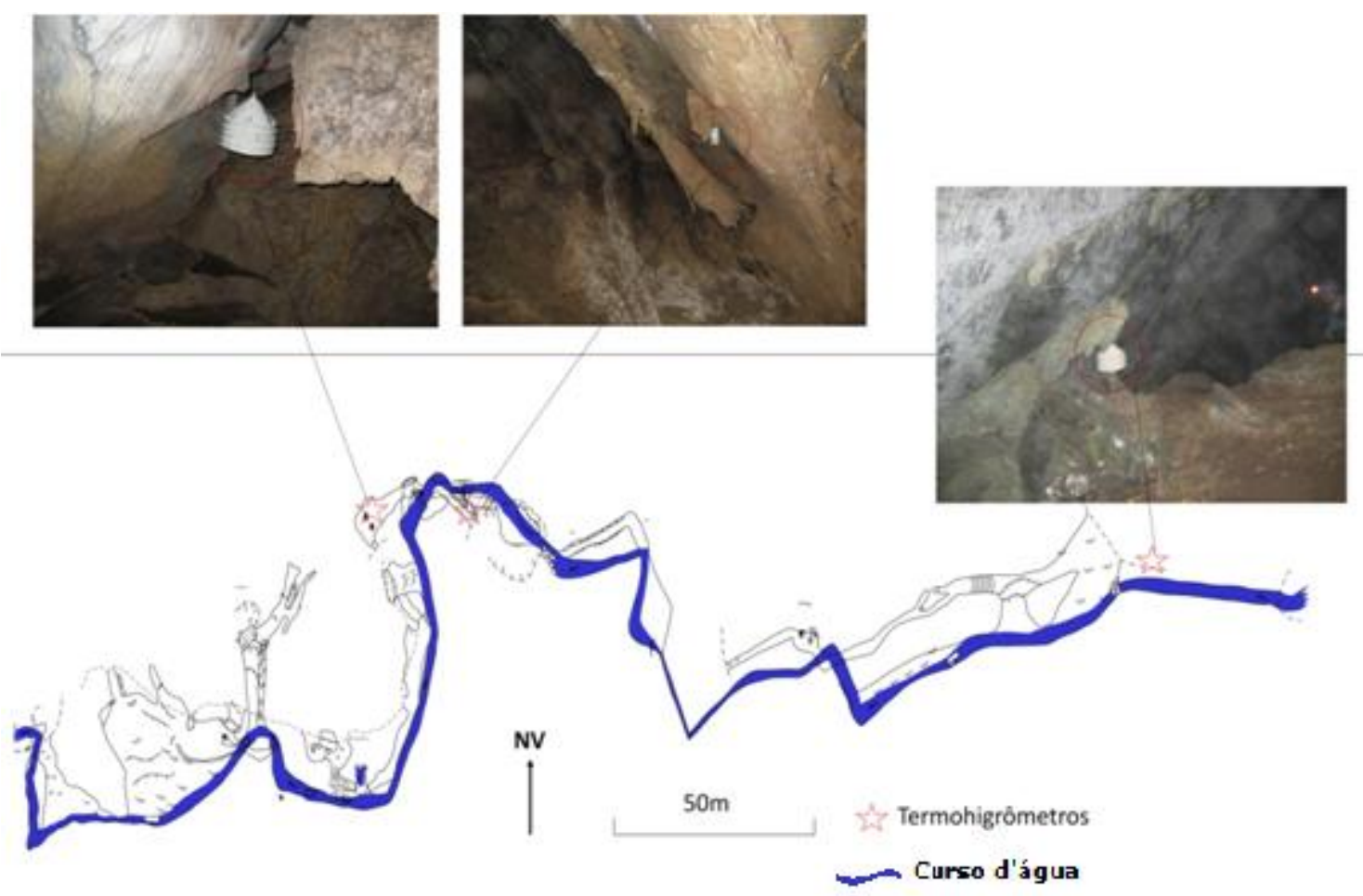

Figura 5.6.1: Localização dos termohigrômetros na Gruta do Fendão. Organização e fotografias: Bárbara N. Rocha, 2010. Fonte: Instituto EKOS, 2009.

Os dados resultantes foram analisados a partir de parâmetros estatísticos e podem ser visualizados na tabela 5.6.1.

O termógrafo localizado na entrada da gruta apresentou problemas, iniciando seus registros somente na madrugada do dia 3 de março. Considerando esse período mais curto, a média registrada neste local foi de $15,8^{\circ} \mathrm{C}$, menor que as médias internas que foi de $18,0^{\circ} \mathrm{C}$ no salão visitável e na área sem visitação. Conforme mencionado anteriormente, a entrada da caverna apresenta um paredão rochoso que a protege do Sol, permitindo um rebaixamento da temperatura. No meio interno, a água do rio, a elevada umidade do ar e o recobrimento rochoso, impedem com que a temperatura caia durante a madrugada. 
Tabela 5.6.1: Parâmetros estatísticos da temperatura e umidade relativa do ar da Gruta do Fendão (período de 28/02 a 07/03/2009).

\begin{tabular}{|l|ccc|ccc|}
\cline { 2 - 7 } \multicolumn{1}{c|}{} & \multicolumn{3}{c|}{ Temperatura do ar $\left({ }^{\circ} \mathrm{C}\right)$} & \multicolumn{3}{c|}{ Umidade relativa do ar (\%) } \\
\cline { 2 - 7 } \multicolumn{1}{c|}{} & Entrada & $\begin{array}{c}\text { Salão } \\
\text { Visitável }\end{array}$ & $\begin{array}{c}\text { Salão não } \\
\text { Visitável }\end{array}$ & Entrada & $\begin{array}{c}\text { Salão } \\
\text { Visitável }\end{array}$ & $\begin{array}{c}\text { Salão não } \\
\text { Visitável }\end{array}$ \\
\hline Máximo & 15,8 & 18,0 & 18,0 & 100,0 & 100,0 & 100,0 \\
Mínimo & 16,5 & 18,1 & 18,1 & 100,0 & 100,0 & 100,0 \\
Amplitude & 14,6 & 17,8 & 17,8 & 100,0 & 100,0 & 100,0 \\
Moda & 1,9 & 0,3 & 0,3 & 0,0 & 0,0 & 0,0 \\
Variância & 16,0 & 18,0 & 18,0 & 100,0 & 100,0 & 100,0 \\
Desvio padrão & 0,2 & 0,0 & 0,0 & 0,0 & 0,0 & 0,0 \\
\hline
\end{tabular}

As máximas foram encontradas dentro da caverna, sendo de $18,1^{\circ} \mathrm{C}$ nos dois salões. A mínima ocorreu na entrada, devido à configuração deste ponto, sendo de $14,6^{\circ} \mathrm{C}$.

As amplitudes térmicas da Gruta do Fendão foram baixas: $1,9^{\circ} \mathrm{C}$ na entrada e $0,3^{\circ} \mathrm{C}$ nos pontos de monitoramento internos. Esta estabilidade atmosférica decorre da elevada umidade do ambiente, o que pode ser comprovado pela análise dos dados de umidade relativa do ar. Em todos os locais estudados, o ar ficou saturado durante toda a semana, com médias, máximos, mínimos e modas iguais a 100\% e amplitudes, variâncias e desvios padrões nulos. O rio é o principal provedor de umidade nesta caverna.

A moda das temperaturas do meio interno foram iguais à média, reforçando as baixas flutuações ambientais destes locais. As variâncias tendem a zero e o desvio padrão foi de 0,1. Na entrada, o valor mais comumente encontrado foi de $16,0^{\circ} \mathrm{C}$, superior a média. A variância foi de 0,2 e o desvio padrão de 0,4.

A figura 5.6.2 mostra a variação da temperatura do ar na Gruta do Fendão ao longo da semana. No eixo da esquerda pode-se analisar os dados do meio externo (estação meteorológica) e da entrada da caverna. Já os dados dos salões visitável e não visitável podem ser visualizados no eixo da direita. 


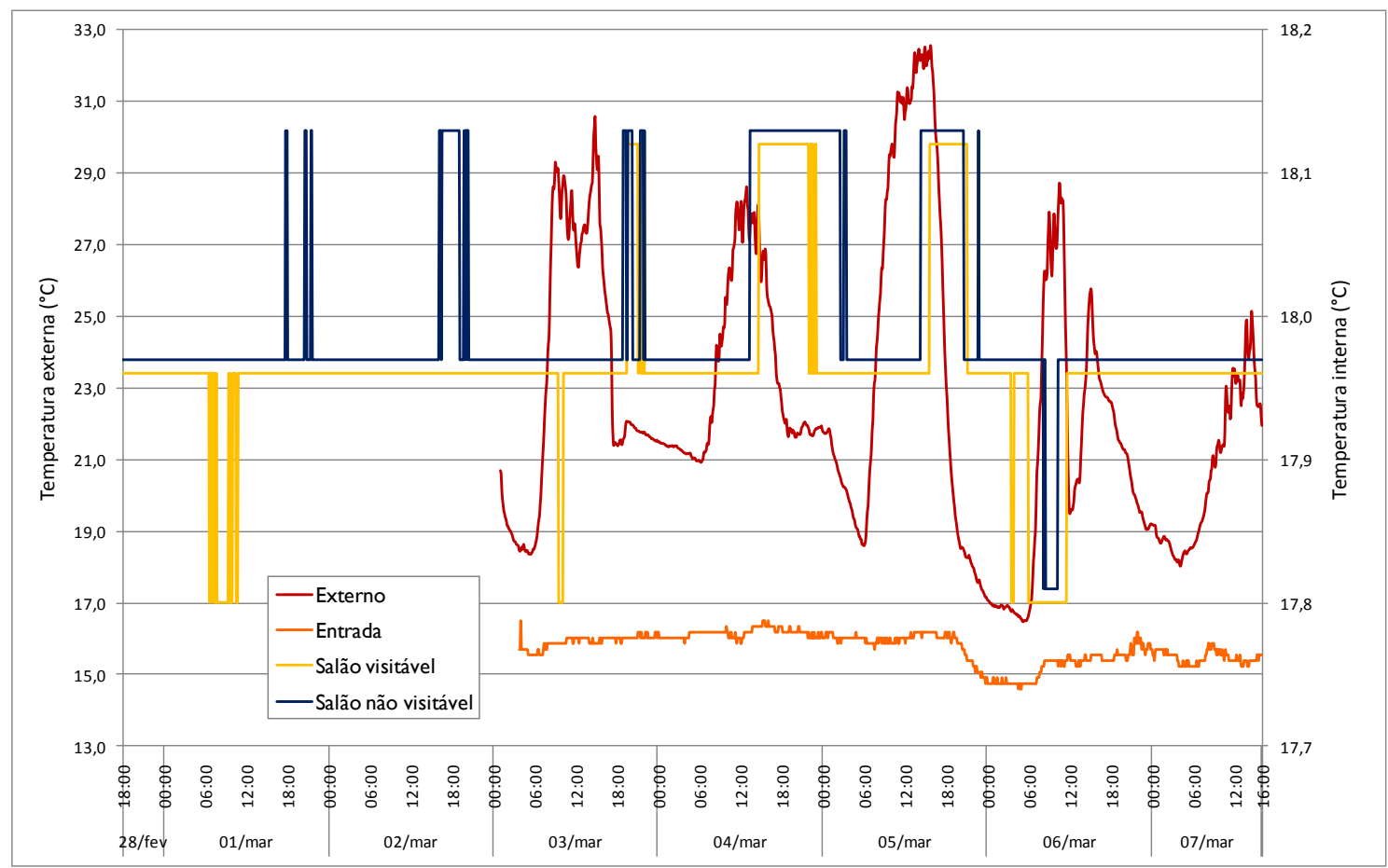

Figura 5.6.2: Variação da temperatura do ar $\left({ }^{\circ} \mathrm{C}\right)$ na Gruta do Fendão. Organização: Bárbara N. Rocha, 2010.

Apesar dos problemas ocorridos com o primeiro termohigrômetro, que impediram registros nos primeiros dias, percebe-se que na entrada da caverna o microclima segue a tendência de variação do meio externo, com aumento da temperatura durante o dia e diminuição à noite. As amplitudes são, no entanto, bastante reduzidas. Algumas variações do meio externo não são percebidas na entrada da caverna.

Nos pontos localizados no interior da gruta, a temperatura do ar apresentou pequenas variações, da ordem de alguns décimos, resultados da precisão do sensor. Na área não visitável, em um acesso à galeria superior, a temperatura do ar foi ligeiramente maior que a do salão visitável. Em geral, os dois pontos apresentaram a mesma tendência de mudança.

A Gruta do Fendão é uma das mais visitadas do parque e recebeu nove turistas no período, três que percorreram a caverna no dia 4 de março e seis no dia sete. Nestes dias, o termógrafo da entrada tinha voltado a funcionar, permitindo uma melhor análise.

O grupo de três turistas entrou na caverna às 9h30min e saiu às 10h30min. Nesse intervalo de tempo a temperatura do meio externo permaneceu praticamente constante em $16,1^{\circ} \mathrm{C}$. No interior da gruta, as 
temperaturas não apresentaram nenhuma alteração. No dia 7, antes da retirada dos equipamentos, seis turistas percorreram a caverna. As temperaturas também não variaram na presença desse grupo.

O gráfico a seguir (figura 5.6.3) mostra a variação da umidade relativa do ar na Gruta do Fendão durante o período de estudo.

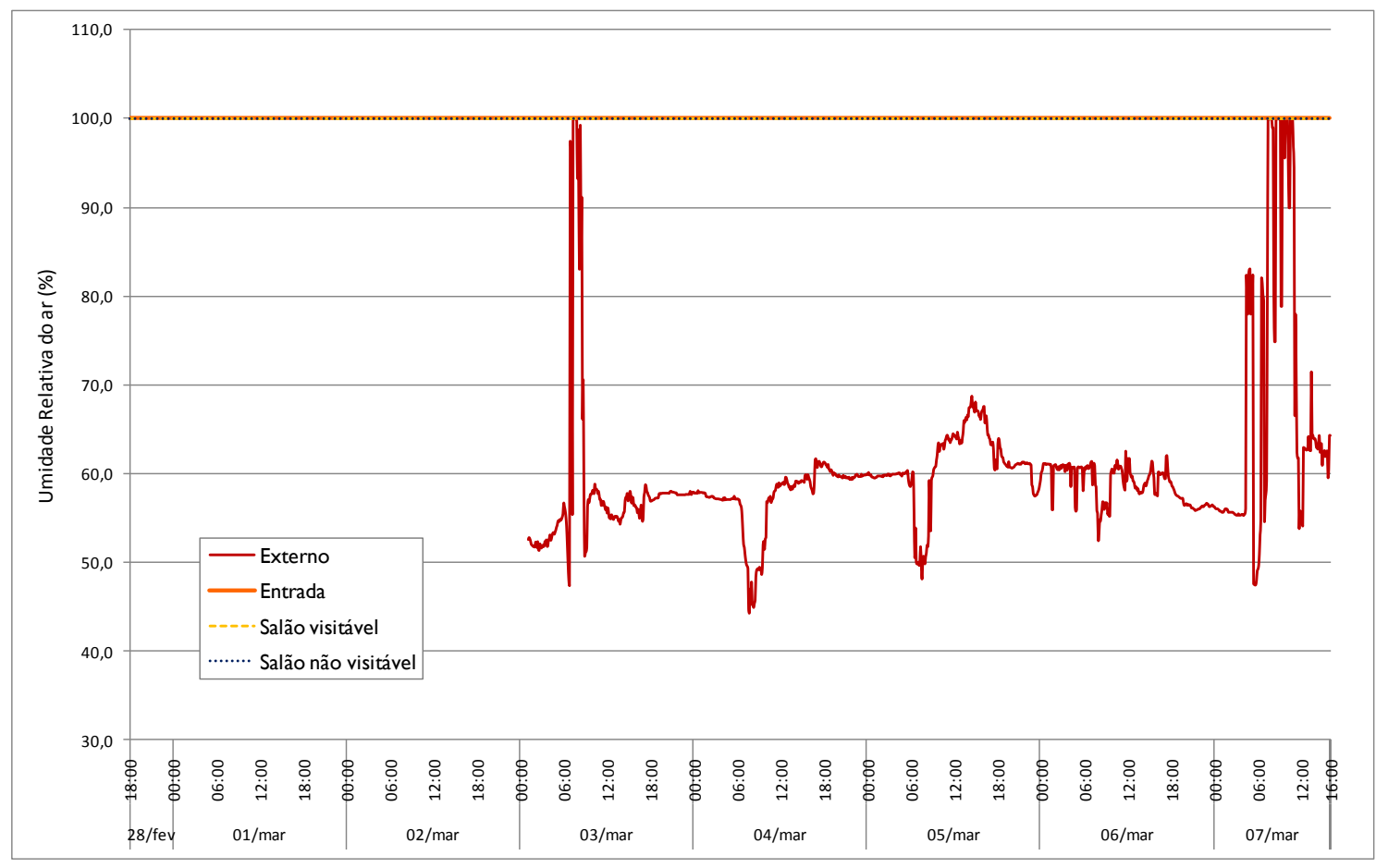

Figura 5.6.4: Variação da umidade relativa do ar (\%) na Gruta do Fendão. Organização: Bárbara N. Rocha, 2010.

A umidade relativa do ar manteve-se em $100 \%$ nos três pontos da caverna durante todo o período. Nem o registrador da entrada da gruta acompanhou as variações do meio externo. A saturação nesta caverna decorre da presença do rio de elevado volume e águas correntes e do capeamento rochoso. Na entrada, a vegetação impede a entrada de radiação solar direta e provém umidade para a atmosfera por causa da evapotranspiração.

O perfil de gás carbônico da cavidade é apresentado na figura que se segue. Os dados de $\mathrm{CO}_{2}$ foram coletados no dia 7 de março, no final da tarde. 


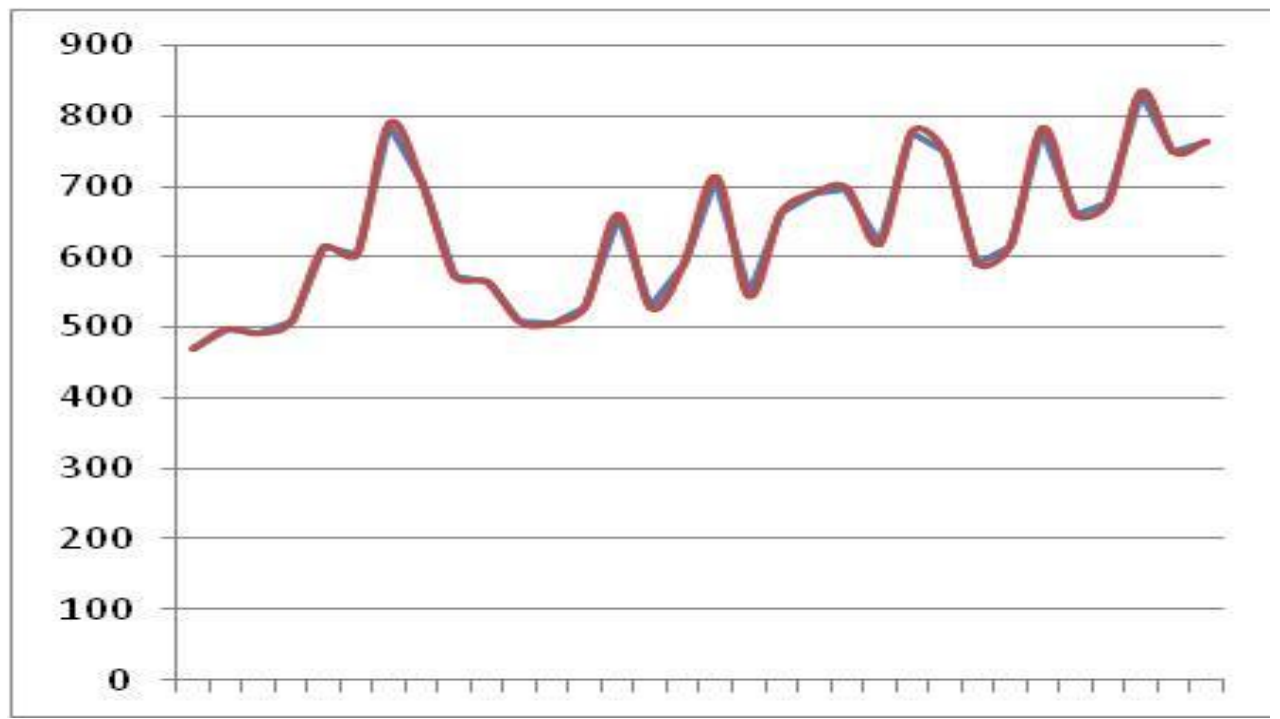

Figura 5.6.5: Perfil de gás carbônico da Gruta do Fendão.

Organização: Bárbara N. Rocha, 2010.

As concentrações de gás carbônico variaram bastante, não apresentando nenhuma tendência em sua concentração. O que pôde ser percebido empiricamente é que a concentração do gás varia de acordo com a ventilação da caverna e não pela sua configuração. Como as trocas energéticas são intensas nessa gruta e a ventilação é facilitada pelo teto elevado, pela presença de claraboias e pelo fluxo do rio, as brisas que sopravam em alguns momentos eram as responsáveis pela redução na concentração de $\mathrm{CO}_{2}$.

Esta caverna apresenta o percurso mais difícil, obrigando o visitante a fazer um maior esforço físico em sua travessia, fato que lançaria maior quantidade de gás carbônico em seu interior. No entanto, a boa ventilação da gruta do Fendão facilita as trocas atmosféricas, impedindo o aumento da concentração do gás.

Pelo exposto conclui-se que a Gruta do Fendão não apresentou alterações em sua atmosfera na presença de turistas. Esta caverna não deve apresentar alterações com grupos maiores devido à sua elevada capacidade de troca energética com o meio externo. 


\section{7 - Gruta da Mãozinha}

A Gruta da Mãozinha pertence ao mesmo complexo da Gruta do Fendão, localizando-se próxima a uma de suas entradas. É uma gruta de pequena dimensão, constituída por uma única galeria. Sua entrada tem vista para um fundo de vale vegetado, por onde corre o rio que cruza a Gruta do Fendão. Seu interior não apresenta corpos d'água, porém o solo e as paredes da cavidade são extremamente úmidos, recobertos por argila. Não apresenta claraboias ou entradas secundárias, sendo seu interior totalmente afótico.

A figura 5.7.1 mostra a localização dos registradores de temperatura e umidade relativa do ar na Gruta da Mãozinha. Estes ficaram em campo dos dias 13 a 20 de fevereiro de 2009.

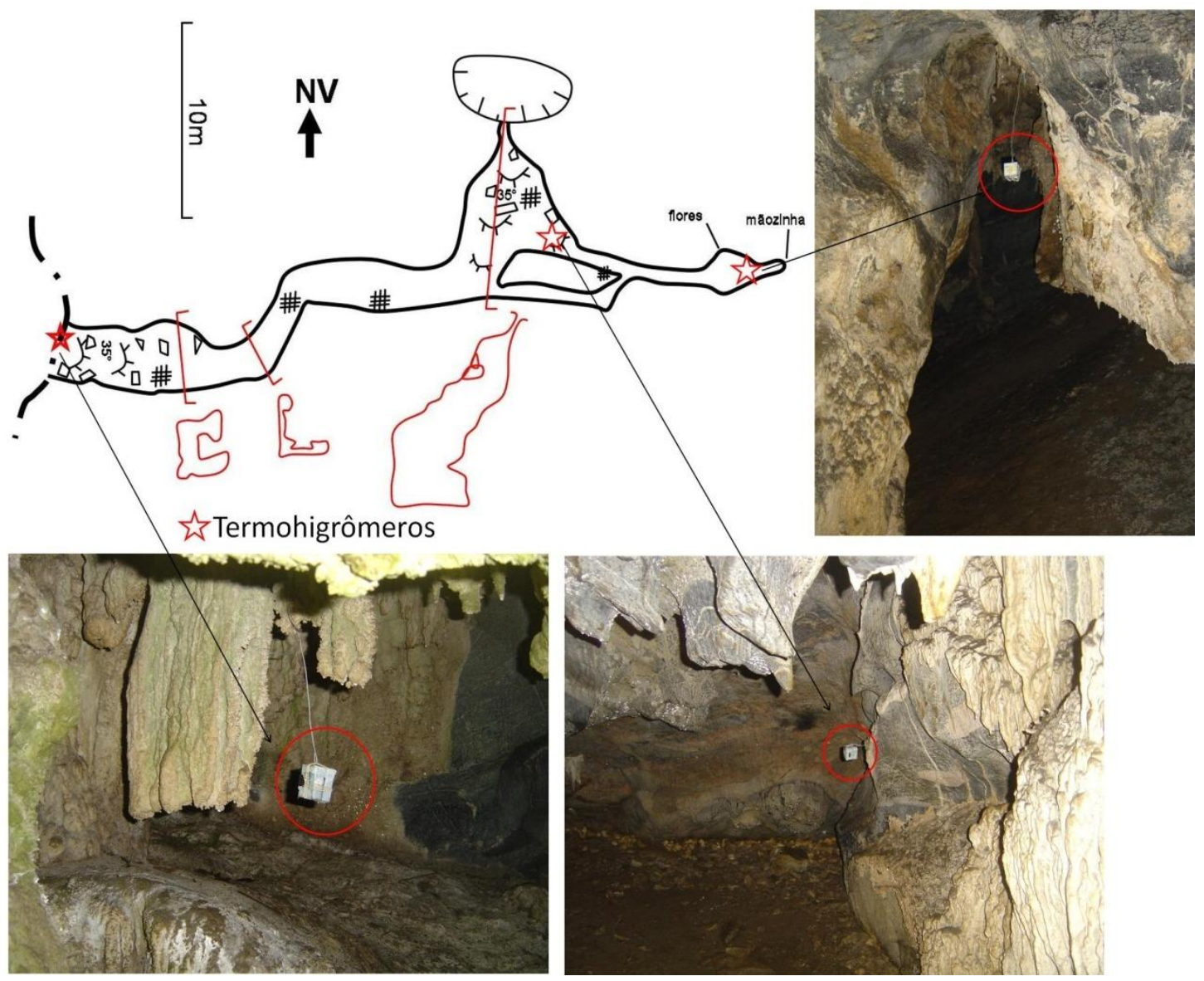

Figura 5.7.1: Localização dos termohigrômetros na Gruta da Mãozinha.

Organização e fotografias: Bárbara N. Rocha. Fonte: Instituto EKOS, 2009. 
Na entrada da caverna foi instalado o primeiro sensor, de modo a caracterizar o microclima de transição entre os meios interno e externo. A radiação solar que chega a este ponto é, principalmente, difusa, devido à presença de vegetação arbórea na frente da cavidade.

O segundo sensor foi instalado em uma bifurcação existente no meio da galeria. O caminhamento preferencial para se chegar à "mãozinha", espeleotema que deu nome à gruta, é feito pela direita. Assim, o sensor foi instalado na passagem da esquerda, única área da caverna em que não costuma haver visitação turística.

No final da galeria, próximo à "mãozinha", foi instalado o terceiro termohigrômetro. Este local é o mais visitado da caverna.

Os dados gerados nos três pontos foram trabalhados estatisticamente e podem ser visualizados na tabela a seguir. Foram extraídas as médias, máximos, mínimos, amplitudes, modas, medianas, variâncias e desvios padrões das amostras de temperatura e umidade.

Tabela 5.7.1: Parâmetros estatísticos da temperatura e umidade relativa do ar da Gruta da Mãozinha (período de 13 a 20/02/2009).

\begin{tabular}{|l|ccc|cc|}
\cline { 2 - 6 } \multicolumn{1}{c|}{} & \multicolumn{3}{c|}{ Temperatura do ar $\left({ }^{\circ} \mathrm{C}\right)$} & \multicolumn{2}{c|}{ Umidade relativa do ar (\%) } \\
\cline { 2 - 6 } \multicolumn{1}{c|}{} & Entrada & $\begin{array}{c}\text { Salão } \\
\text { Visitável }\end{array}$ & $\begin{array}{c}\text { Salão não } \\
\text { Visitável }\end{array}$ & $\begin{array}{c}\text { Salão } \\
\text { Visitável }\end{array}$ & $\begin{array}{c}\text { Salão não } \\
\text { Visitável }\end{array}$ \\
\hline Média & 18,5 & 17,0 & 17,7 & 100,0 & 100,0 \\
Mínimo & 21,7 & 17,8 & 18,5 & 100,0 & 100,0 \\
Amplitude & 17,2 & 16,7 & 17,2 & 100,0 & 100,0 \\
Moda & 4,5 & 1,1 & 1,3 & 0,0 & 0,0 \\
Variância & 17,2 & 17,0 & 17,5 & 100,0 & 100,0 \\
Desvio padrão & 1,0 & 0,0 & 0,1 & 0,0 & 0,0 \\
\hline
\end{tabular}

Organização: Bárbara N. Rocha, 2010.

A maior média térmica foi encontrada na entrada da cavidade, sendo de $18,5^{\circ} \mathrm{C}$. No meio da galeria a média foi de $17,7^{\circ} \mathrm{C}$ e no final de $17,0^{\circ} \mathrm{C}$. $\mathrm{O}$ termohigrômetro localizado na entrada também apresentou a máxima temperatura do período $\left(21,7^{\circ} \mathrm{C}\right)$. Já a mínima ocorreu no salão visitável $\left(16,7^{\circ} \mathrm{C}\right)$.

Como era esperado, a maior amplitude, de $4,5^{\circ} \mathrm{C}$, ocorreu na entrada da gruta, onde a incidência de radiação solar difusa faz a temperatura aumentar durante o dia e, a ausência de proteção pelo capeamento 
rochoso, permite com que ela caia mais acentuadamente à noite. Nos pontos localizados no meio interno as amplitudes não passaram de $1,3^{\circ} \mathrm{C}$.

A moda calculada na entrada foi de $17,2^{\circ} \mathrm{C}$. No interior da gruta, as modas estiveram próximas à média.

Devido às maiores variações, a entrada apresentou a maior variância e desvio padrão $(1,0)$. Nos salões visitável e não visitável, esses parâmetros foram menores, sendo o desvio padrão das amostras de 0,3 no meio da galeria e de 0,2 no final dela.

O higrômetro alocado na entrada da gruta apresentou problemas devido à entrada de água no sensor por escorrimento proveniente da rocha que o protegia. Assim, dados desse atributo não puderam ser coletados nesse ponto. O mesmo problema também ocorreu com o termógrafo deste ponto, que parou de funcionar no dia 18/02 às $14 \mathrm{~h} 30 \mathrm{~min}$.

No meio interno, o ar esteve saturado durante todo o período. Assim, as médias, máximos, mínimos e modas foram iguais a 100\%. As amplitudes, variâncias e desvio padrões foram nulos, consequentemente.

Na figura 5.7.2, pode-se analisar a variação da temperatura do ar da Gruta da Mãozinha e compará-la aos dados obtidos pela estação meteorológica externa. No eixo da esquerda, visualiza-se os dados do meio externo e da entrada da gruta. Os dados do interior da cavidade estão no eixo da direita.

Na entrada da gruta, a temperatura acompanhou o ciclo diuturno, pois deste ponto se "enxerga" a atmosfera exterior, com entrada de radiação solar direta e difusa. Ao decorrer da semana, a temperatura foi apresentando elevação durante o dia, aumentando a amplitude térmica diária. Os pontos localizados no meio interno acompanharam este ciclo, porém com menores amplitudes e atraso na assimilação do tempo exterior.

A pequena dimensão da caverna e sua localização em frente a um fundo de vale faz com que haja troca de energia em todos os seus salões. Dessa forma, a temperatura não permanece constante, sempre apresentando flutuações. 


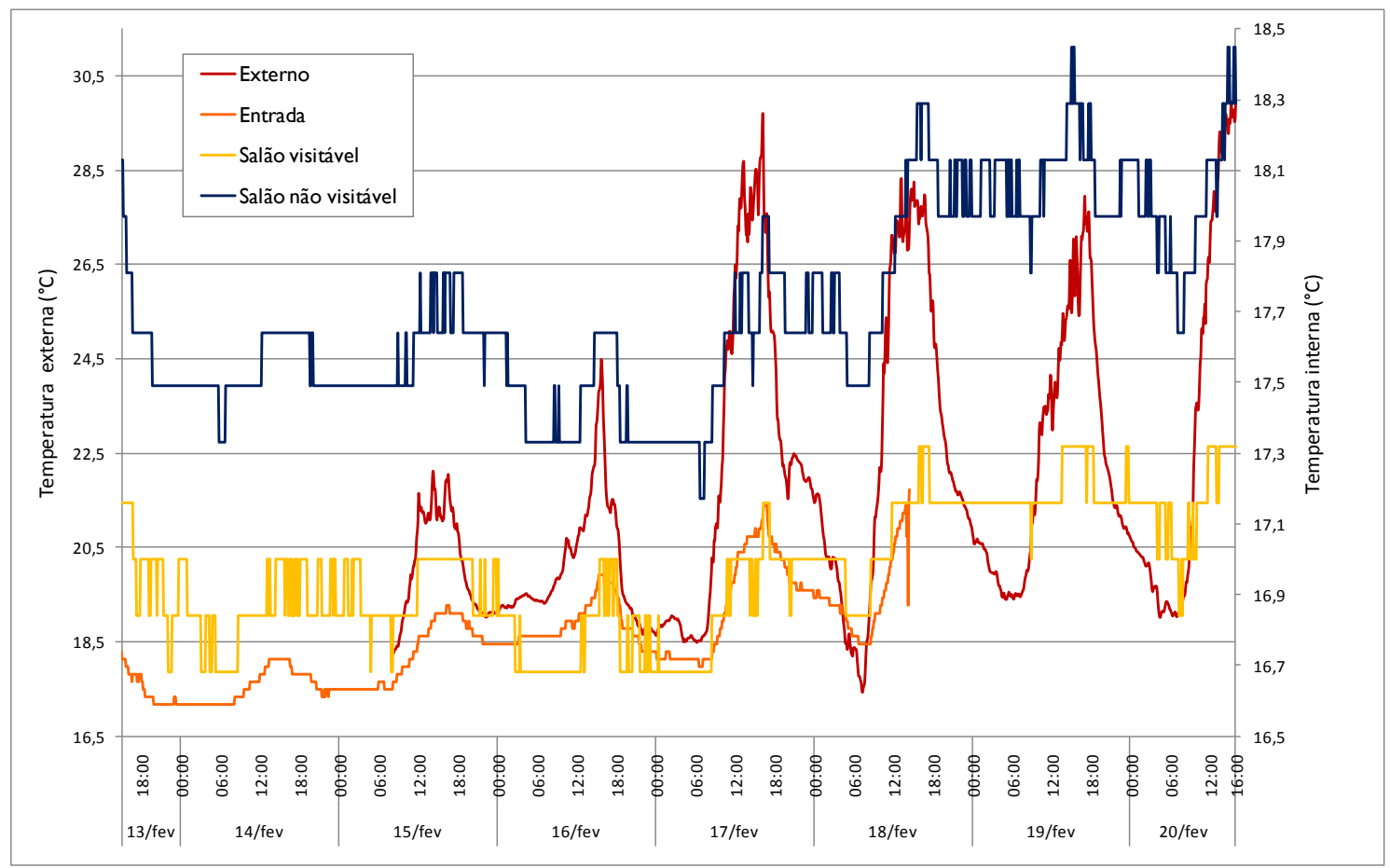

Figura 5.7.2: Variação da temperatura do ar ( $\left.{ }^{\circ} \mathrm{C}\right)$ na Gruta da Mãozinha. Organização: Bárbara N. Rocha, 2010.

No dia 15/02, um grupo de três turistas visitou a caverna, permanecendo em seu interior das $12 \mathrm{~h} 25 \mathrm{~min}$ às $12 \mathrm{~h} 35 \mathrm{~min}$. Neste dia, a temperatura do ponto mais interior da caverna já apresentou elevação desde às $11 \mathrm{~h} 20 \mathrm{~min}$, mantendo-se constante em $17,6^{\circ} \mathrm{C}$ até às $14 \mathrm{~h} 30 \mathrm{~min}$. Pode-se concluir, portanto, que o grupo de turistas não apresentou impacto na atmosfera cavernícola.

Os dados de umidade relativa do ar podem ser visualizados na figura 5.7.3.

Conforme analisado anteriormente a partir dos dados mostrados na tabela 5.7.1, a umidade relativa do ar não apresentou variações no interior da gruta, mantendo-se constante em 100\%. A saturação do ar pôde ser percebida em campo pela constante umidade das paredes rochosas e pelo solo molhado, bastante liso. 


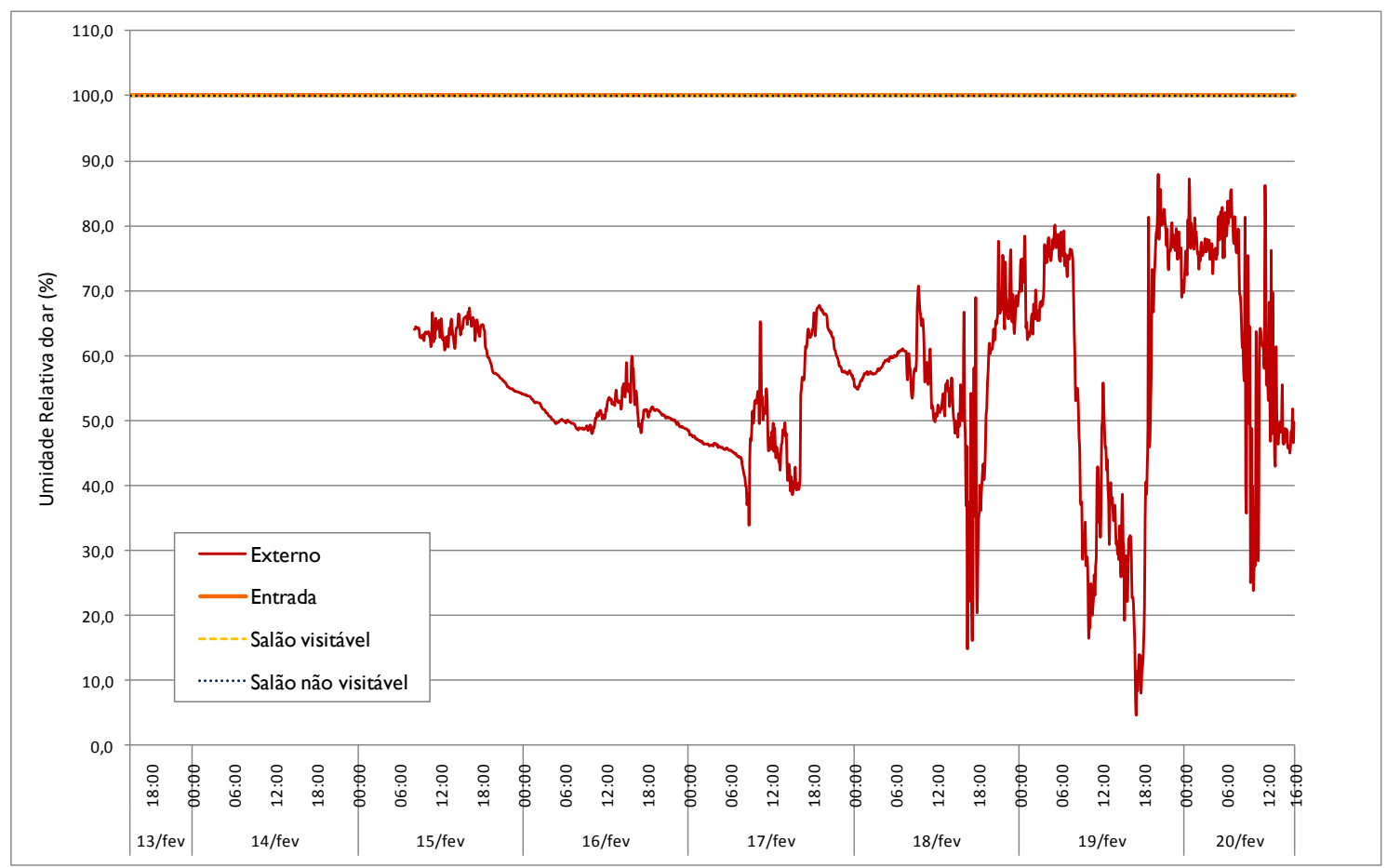

Figura 5.7.3: Variação da umidade relativa do ar $\left({ }^{\circ} \mathrm{C}\right)$ na Gruta da Mãozinha.

Organização: Bárbara N. Rocha, 2010.

A próxima figura mostra o perfil de gás carbônico da Gruta da Mãozinha (figuras 5.7.4). O perfil foi realizado no dia 20/02 na presença de quatro pessoas.

Em condições naturais, o gás carbônico varia de 455 ppm a 760 ppm. $\mathrm{Na}$ entrada, a taxa de $\mathrm{CO}_{2}$ estava mais baixa, apresentando elevação na parte central da galeria, voltando a diminuir no salão da "mãozinha".

Optou-se pela realização de um teste de visitação com uso de carbureteira. Após a ligação do aparelho, a concentração de gás carbônico no final da galeria saltou de 760 ppm para 1695 ppm, como pode ser visualizado na figura. Mesmo depois que a carbureteira foi desligada, as concentrações de $\mathrm{CO}_{2}$ mantiveram-se elevadas até a saída do grupo. Esse resultado vai de encontro ao trabalho de Scaleante (2003), que provou que ambientes impactados pela presença de visitantes usando iluminação a carbureto, demoram a voltar à situação inicial. 


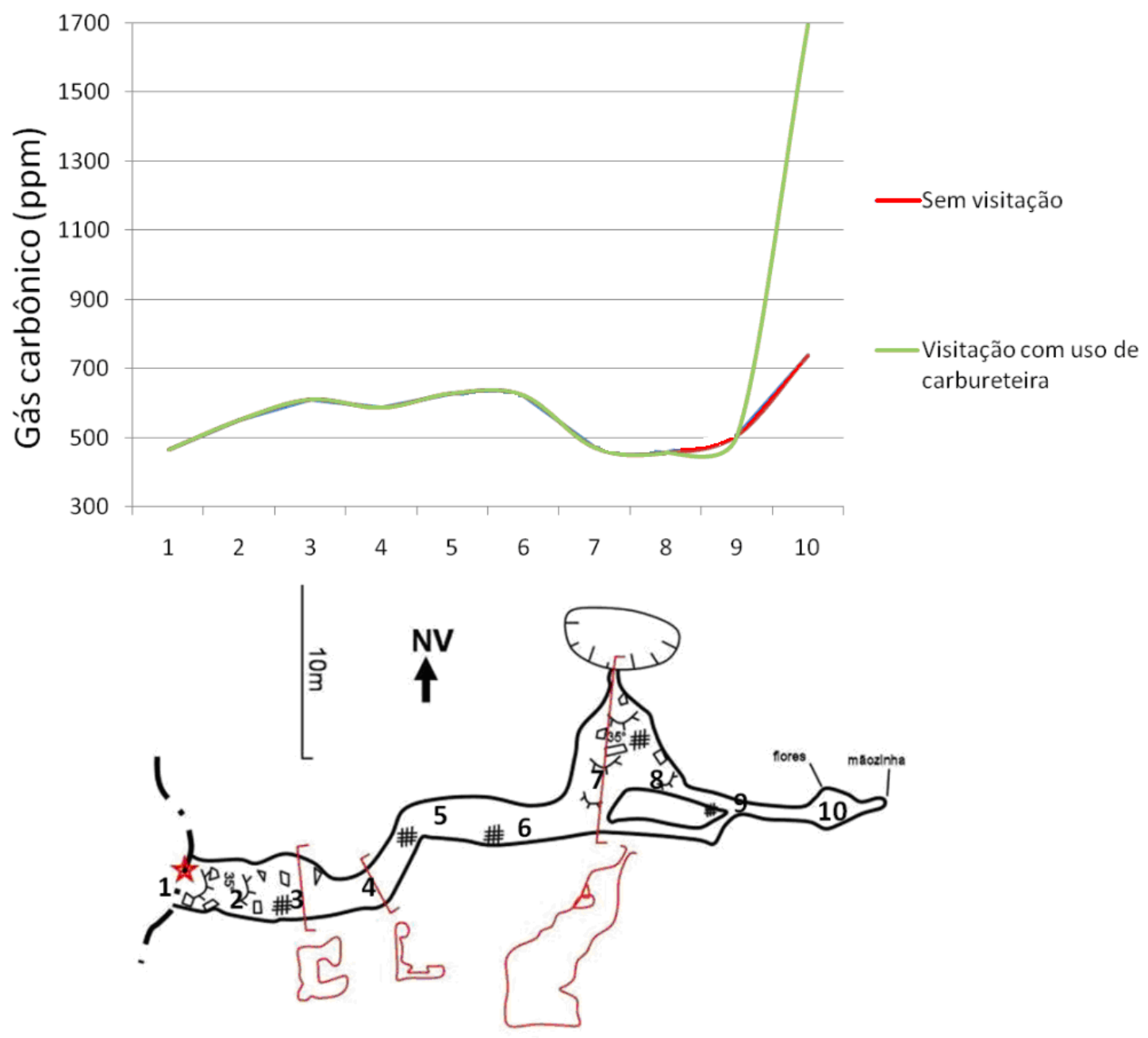

5.7.4: Perfil de gás carbônico da Gruta da Mãozinha.

Organização: Bárbara N. Rocha, 2010. Fonte: Instituto EKOS, 2009.

Pelo exposto, não foram encontrados impactos em condições normais de visitação (sem uso de carbureteira) na atmosfera da Gruta da Mãozinha. Outrossim, foi possível concluir que o turismo com uso de carbureteiras resulta em um acréscimo significativo nas taxas de gás carbônico.

\section{8 - Gruta da Santa}

A Gruta da Santa apresenta uma única entrada de grande amplitude o que lhe confere boa ventilação. Constitui-se de uma única galeria, com corredores amplos. Um pequeno curso d'água corre em parte de seu interior. 
Os pontos de monitoramento de temperatura e umidade relativa do ar na Gruta da Santa podem ser visualizados na figura 5.8.1. Os dados foram colhidos entre os dias 14 e 20 de fevereiro.

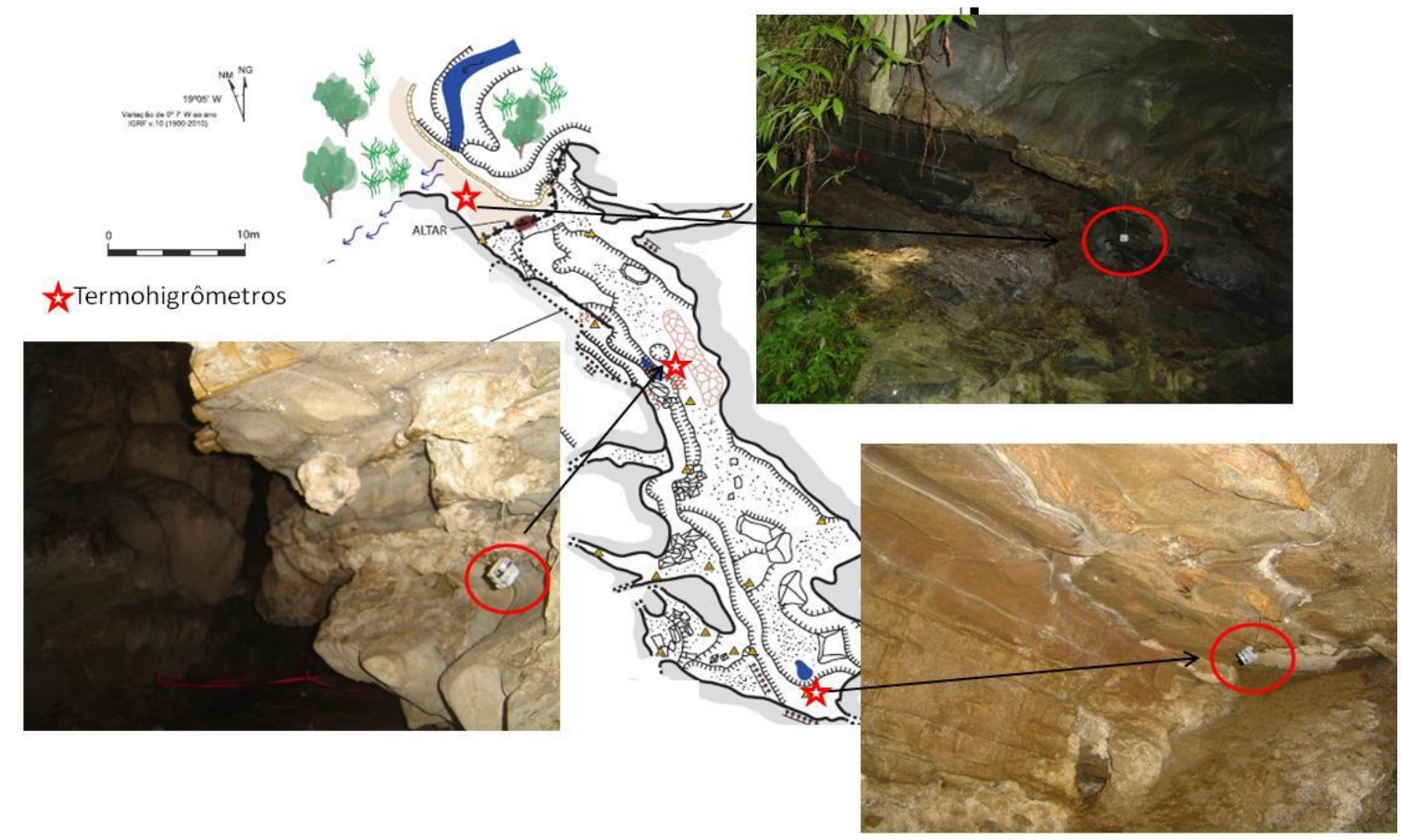

Figura 5.8.1: Localização dos termohigrômetros na Gruta da Santa. Organização e fotografias: Bárbara N. Rocha, 2010. Fonte: Instituto EKOS, 2009.

O primeiro termohigrômetro foi instalado na entrada da gruta, próximo ao altar. Como a entrada da caverna é ampla e a vegetação a sua frente é composta principalmente por grama baixa, este local recebe radiação solar direta e difusa. A boca voltada para o norte permite com que a radiação incida durante todo o dia.

O próximo local de monitoramento fica no meio da cavidade, no circuito tradicional de visitação, próximo ao curso d'água e a um travertino. Neste local, os visitantes param para admirar o espeleotema, sendo, assim, um local de grande visitação.

O último termohigrômetro foi instalado no final do duto, onde não há visitação turística.

A tabela 5.8.1 apresenta alguns parâmetros estatísticos, calculados a partir dos dados de temperatura e umidade relativa do ar colhidos ao longo da semana. Os parâmetros escolhidos para análise foram: média, máximo, mínimo, amplitude, moda, variância e desvio padrão. 
Tabela 5.8.1: Parâmetros estatísticos da temperatura e umidade relativa do ar da Gruta da Santa (período de 14 a 20/02/2009).

\begin{tabular}{|l|ccc|ccc|}
\cline { 2 - 7 } \multicolumn{1}{c|}{} & \multicolumn{3}{c|}{ Temperatura do ar $\left({ }^{\circ} \mathrm{C}\right)$} & \multicolumn{3}{c|}{ Umidade relativa do ar (\%) } \\
\cline { 2 - 7 } \multicolumn{1}{c|}{} & Entrada & $\begin{array}{c}\text { Salão } \\
\text { Visitável }\end{array}$ & $\begin{array}{c}\text { Salão não } \\
\text { Visitável }\end{array}$ & Entrada & $\begin{array}{c}\text { Salão } \\
\text { Visitável }\end{array}$ & $\begin{array}{c}\text { Salão não } \\
\text { Visitável }\end{array}$ \\
\hline Média & 16,7 & 17,2 & 17,1 & 99,9 & 100,0 & 100,0 \\
Máximo & 19,4 & 17,5 & 17,3 & 100,0 & 100,0 & 100,0 \\
Mínimo & 14,1 & 17,0 & 16,7 & 68,4 & 100,0 & 100,0 \\
Ammlitude & 5,3 & 0,5 & 0,7 & 31,6 & 0,0 & 0,0 \\
Moda & 16,8 & 17,3 & 17,2 & 100,0 & 100,0 & 100,0 \\
Variância & 1,4 & 0,0 & 0,0 & 2,8 & 0,0 & 0,0 \\
Desvio padrão & 1,2 & 0,1 & 0,1 & 1,7 & 0,0 & 0,0 \\
\hline
\end{tabular}

Organização: Bárbara N. Rocha, 2010.

A menor média térmica $\left(16,7^{\circ} \mathrm{C}\right)$ foi registrada na entrada da caverna, devido às maiores flutuações ambientais neste ponto. Aí também foram encontrados o máximo e o mínimo valor do período $\left(19,4^{\circ} \mathrm{C} \mathrm{e}\right.$ $14,1^{\circ} \mathrm{C}$, respectivamente), resultando na maior amplitude térmica $\left(5,3^{\circ} \mathrm{C}\right)$. Essas variações resultam da radiação incidente durante o dia e da perda de calor durante a noite, visto que não há proteção rochosa neste local.

No salão visitável, localizado no meio da galeria, a temperatura média foi de $17,2^{\circ} \mathrm{C}$, com máxima de $17,5^{\circ} \mathrm{C}$ e mínima de $17^{\circ} \mathrm{C}$, resultando numa amplitude de $0,5^{\circ} \mathrm{C}$. No final do corredor, onde não ocorre visitação, a média foi de $17,1^{\circ} \mathrm{C}$, a máxima de $17,3^{\circ} \mathrm{C}$ e a mínima de $16,7^{\circ} \mathrm{C}$. Apesar de estar mais distante da entrada, este ponto apresentou amplitudes térmicas mais elevadas que o ponto anterior, pois aquele está próximo a um corpo d'água, que ajuda a minimizar as flutuações ambientais.

As modas estiveram próximas das médias, conferindo estabilidade aos dados. Isso se comprova também pelos baixos valores de variância e desvio padrão.

A umidade relativa do ar apresentou-se ainda mais estável. Nos pontos interiores à caverna, o ar sempre esteve saturado, resultando em médias, máximos, mínimos, modas e medianas iguais a $100 \%$ e, consequentemente, amplitudes, variâncias e desvios padrões nulos.

$\mathrm{Na}$ entrada da caverna, os dados apresentaram algumas variações, apesar de a média estar muito próxima do ponto de saturação $(99,9 \%)$ e a 
moda ser de 100\%. A menor UR registrada neste local foi de 68,4\%, resultando em amplitude de 31,6. A variância foi de 2,8 e o desvio padrão de 1,7 . Isso se explica pela localização deste posto de coleta no meio externo, sujeito as variações do ciclo diuturno da temperatura.

O gráfico abaixo (figura 5.8.2) mostra a variação da temperatura do ar no meio externo (estação meteorológica e entrada da gruta - eixo da esquerda) e no interior da gruta (salões visitável e não visitável - eixo da direita).

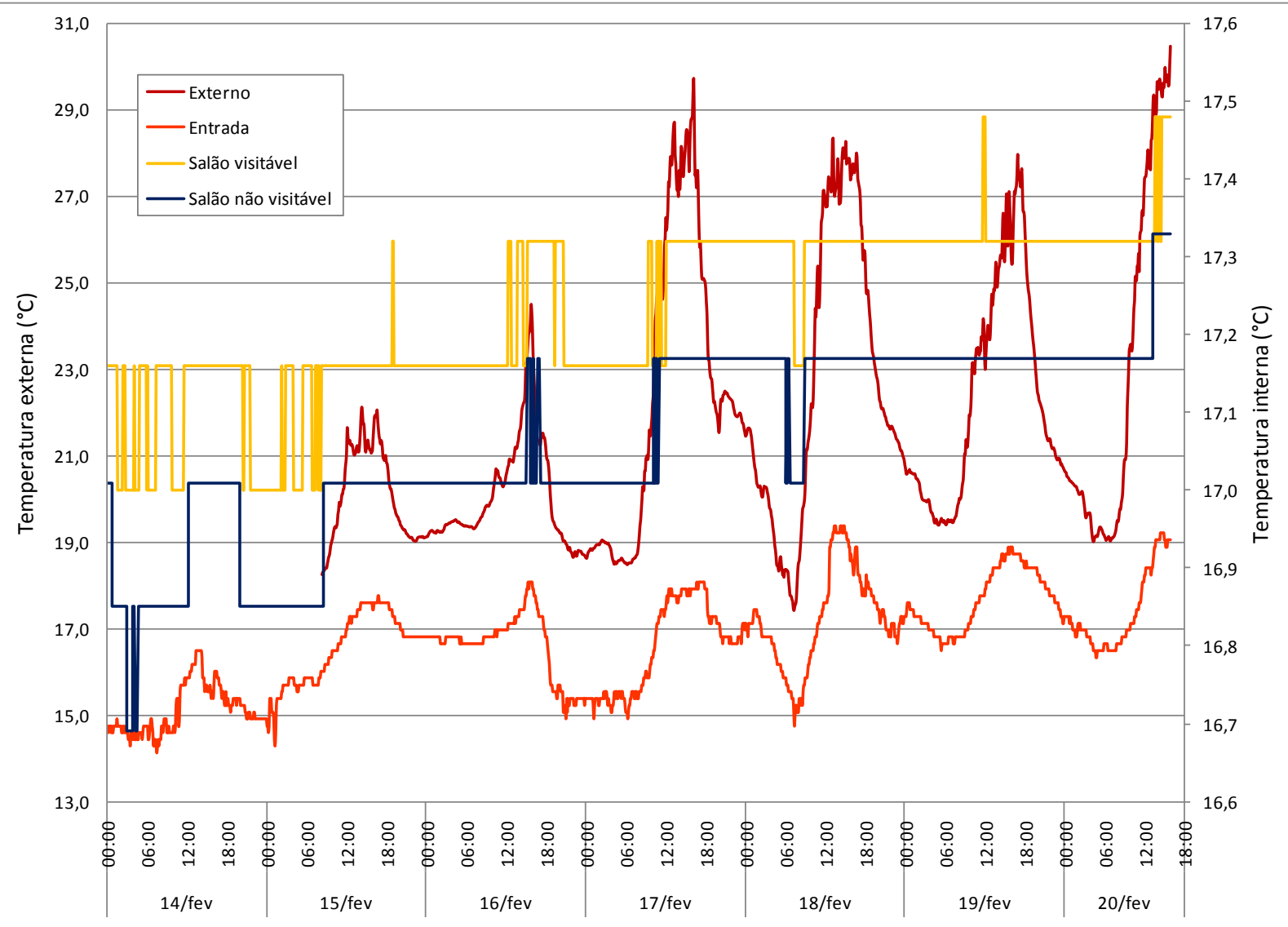

Figura 5.8.2: Variação da temperatura do ar ( $\left.{ }^{\circ} \mathrm{C}\right)$ na Gruta da Santa.

Organização: Bárbara N. Rocha, 2010.

$\mathrm{Na}$ gruta, o local que apresentou as maiores variações de temperatura foi a entrada devido a incidência de radiação solar direta e difusa neste ponto. Os valores acompanham claramente o ciclo entre o dia e a noite, com menores amplitudes térmicas, mas sem atrasos nas assimilações do tempo exterior.

No meio interno, as variações são pequenas, inferiores a $0,5^{\circ} \mathrm{C}$, 
seguindo a tendência de elevação ou diminuição ditadas pelo meio externo. Porém, essa assimilação do tempo exterior apresenta atrasos e não pode ser percebida todos os dias. O salão visitável apresentou temperaturas cerca de $0,2^{\circ} \mathrm{C}$ mais elevadas que as do final da galeria durante todo $\mathrm{o}$ período.

No dia 14, primeiro dia de registros, um grupo de três pessoas visitou a caverna, das $13 \mathrm{~h} 55 \mathrm{~min}$ às $14 \mathrm{~h} 10 \mathrm{~min}$. Neste momento, as temperaturas no interior da cavidade não apresentaram nenhuma alteração, permanecendo constante em $17,2^{\circ} \mathrm{C}$ no salão visitável, desde às $11 \mathrm{~h} 30 \mathrm{~min}$ até às $20 \mathrm{~h} 20 \mathrm{~min}$, e em $17^{\circ} \mathrm{C}$ na área não visitável (figura 5.8.3).

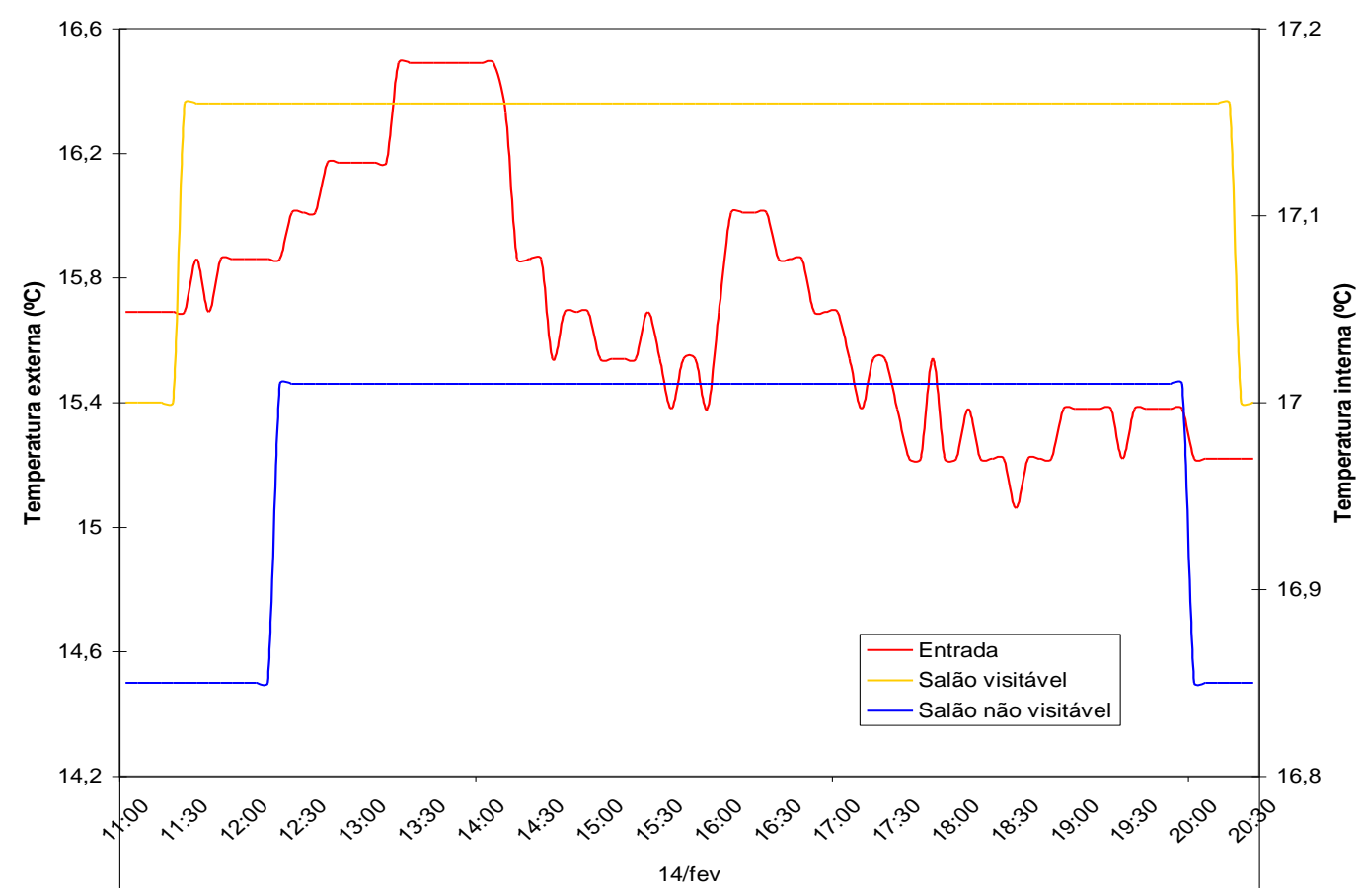

Figura 5.8.3: Variação horária da temperatura do ar no dia 14 de fevereiro na Gruta da Santa.

Organização: Bárbara N. Rocha, 2010.

Portanto, mesmo apresentando certa estabilidade microclimática, grupos pequenos de visitantes não devem provocar alterações na temperatura do ar do interior da gruta da Santa.

A variação da umidade relativa do ar pode ser vista na figura 5.8.4 a seguir. 


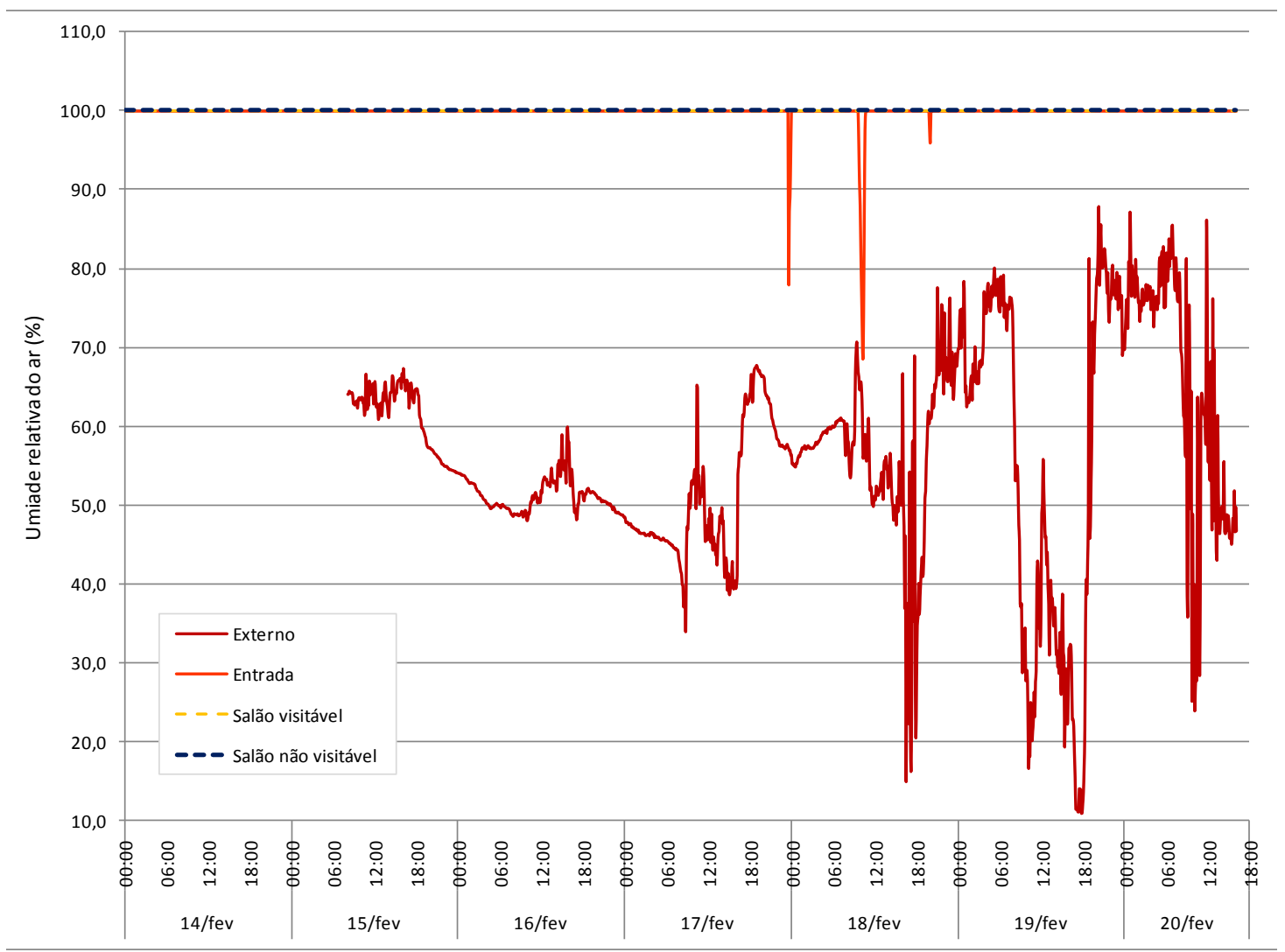

Figura 5.8.4: Variação da umidade relativa do ar (\%) na Gruta da Santa. Organização: Bárbara N. Rocha, 2010.

No interior da caverna, tanto no salão visitável quanto no não visitável, a umidade relativa do ar manteve-se constante em 100\%. Variações puderam ser percebidas somente na entrada da cavidade, nos dias 17 e 18 de fevereiro. As quedas da UR na entrada da caverna não acompanharam as variações registradas pela estação meteorológica, que apresentaram aumento nesses momentos. Os dados de radiação solar global e de velocidade do vento explicam essas oscilações (figuras 5.8.5 e 5.8.6). 


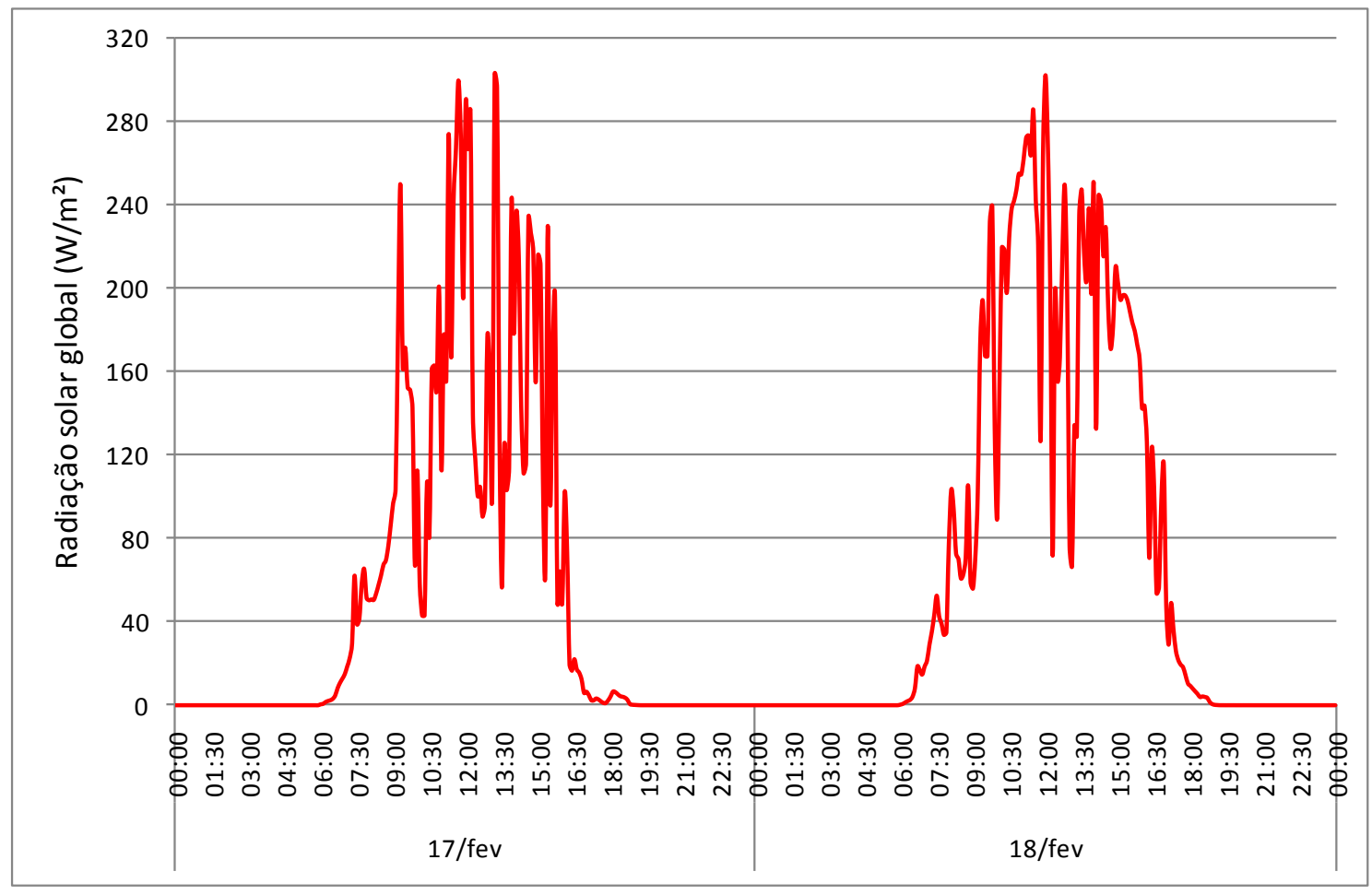

Figura 5.8.5: Variação da radiação solar global na Estação meteorológica automática instalada no P.E. Intervales.

Organização: Bárbara N. Rocha, 2010.

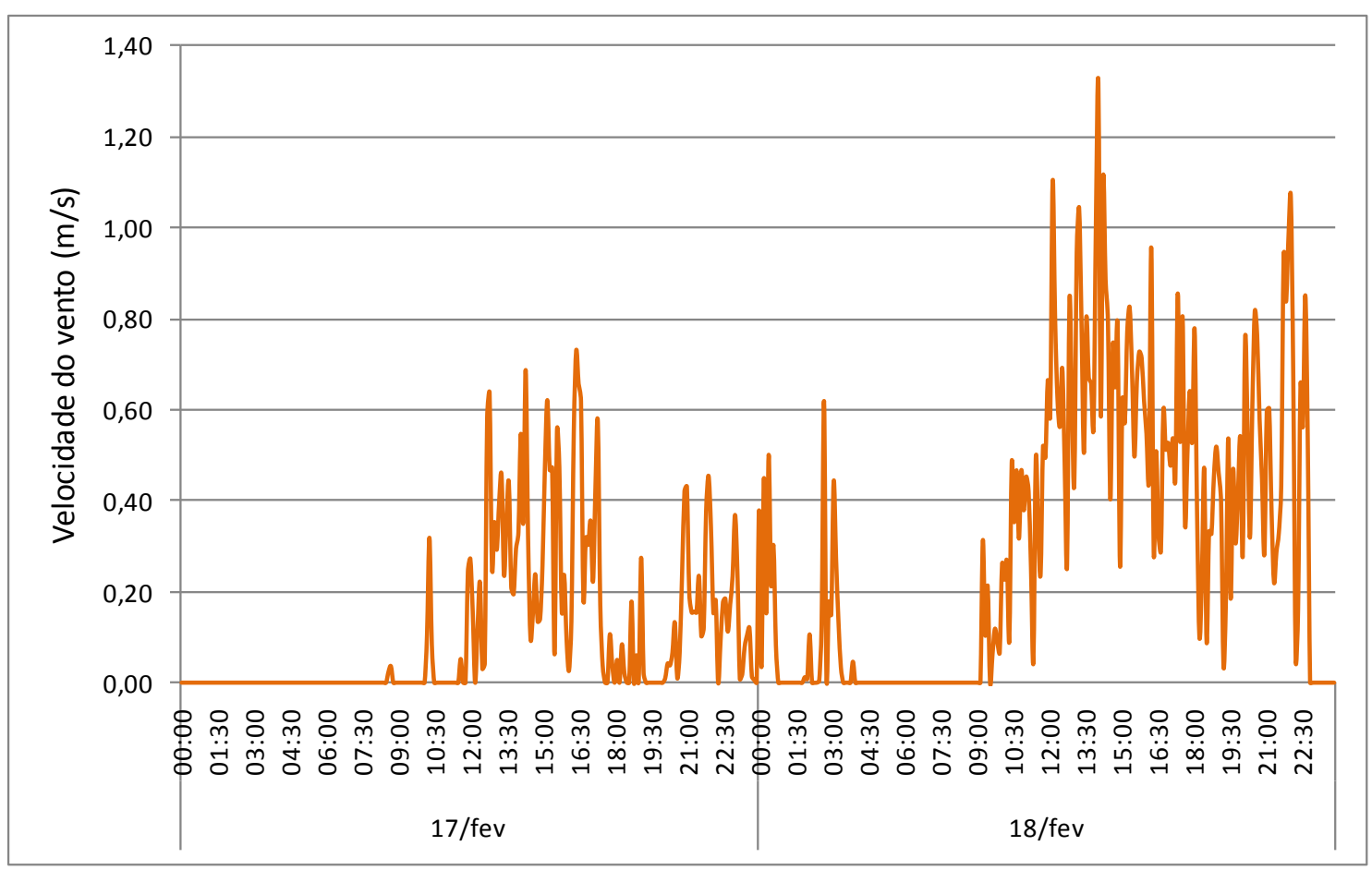

Figura 5.8.6: Velocidade do vento na Estação meteorológica automática instalada no P.E. Intervales.

Organização: Bárbara N. Rocha, 2010. 
Por volta de $13 \mathrm{~h}$ do dia 17 de fevereiro de 2010, o vento passou a apresentar velocidades mais elevadas e provenientes de direção Sudeste. Isso combinado com a orientação da abertura da caverna pode ter contribuído para uma renovação do ar na entrada da caverna, o que pode ter reduzido a umidade relativa do ar neste ponto. Como a entrada da caverna é descampada, ventos podem atingi-la de qualquer direção.

No dia 18, a umidade da entrada diminui por volta das $11 \mathrm{~h} 00 \mathrm{~min}$ da manhã, momento em que a radiação solar direta atingiu seus máximos valores naquele dia. Ventos vindos do Sul também passaram a soprar com maior intensidade neste horário. As variações da UR na entrada da caverna explicam-se, portanto, por fatores naturais.

A figura 5.8.7 apresenta o perfil de dióxido de carbono da Gruta da Santa realizado no dia 20 de fevereiro às 09h00min, na presença de quatro pessoas.

No meio externo, a concentração de gás carbônico é menor (373 ppm) e aumenta gradativamente a medida em que se interioriza no duto, atingindo 499 ppm ao final da galeria.

Apesar da variação, a diferença entre o máximo e o mínimo foi pequena, sendo de 126 ppm, uma das menores amplitudes encontradas.

A taxa de $\mathrm{CO}_{2}$ no interior da gruta é baixa, pois praticamente inexistem espeleotemas na caverna. A formação desses ornamentos é a principal responsável pela liberação do referido gás na atmosfera cavernícola, como descrito por Karmann (2003). 


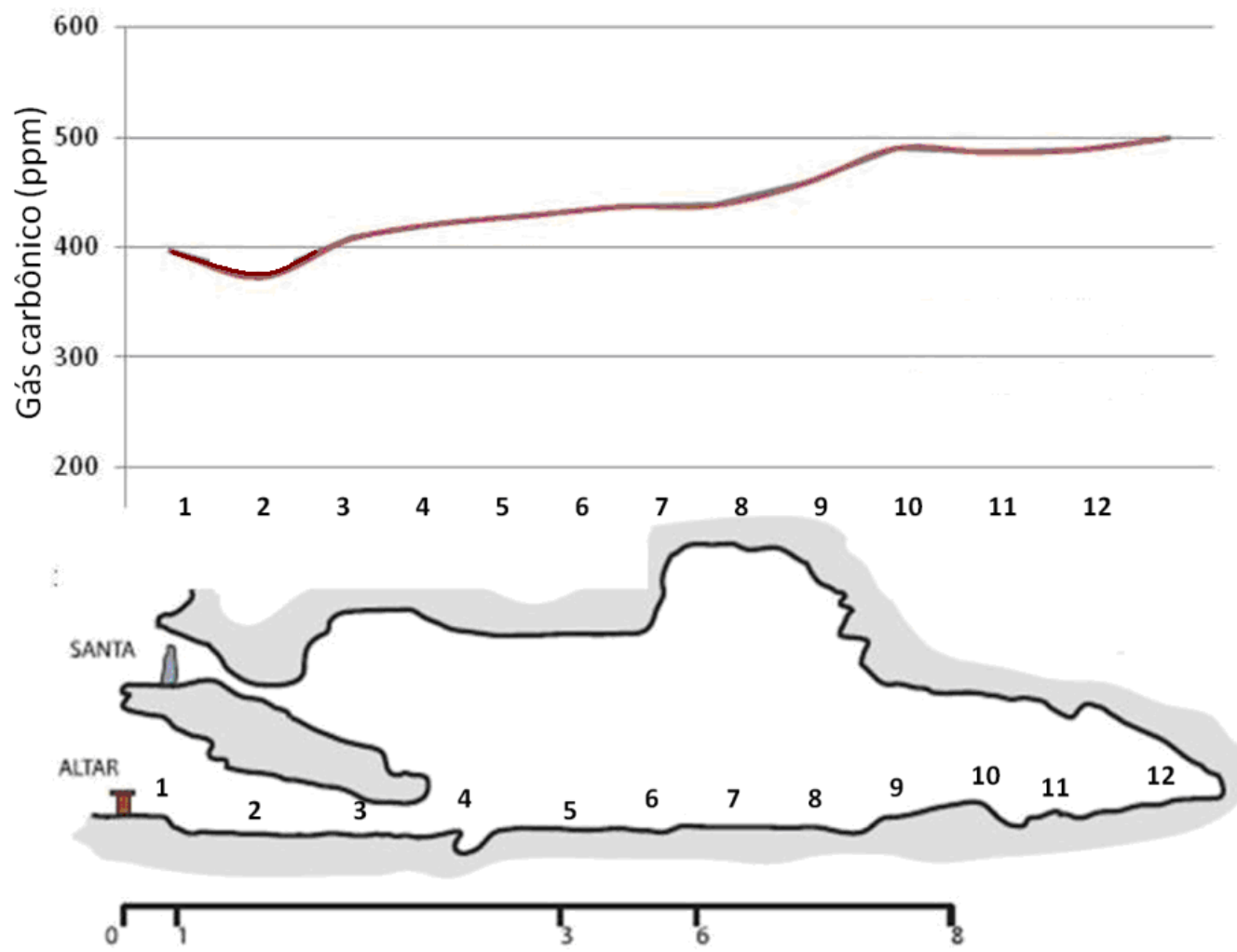

Figura 5.8.7: Perfil de gás carbônico da Gruta da Santa.

Organização: Bárbara N. Rocha, 2010.

Em suma, não foram identificadas variações térmicas e hígricas, bem como na concentração de $\mathrm{CO}_{2}$, na Gruta da Santa em decorrência de visitações turísticas.

\section{9 - Gruta do Minotauro}

A gruta do Minotauro constitui-se por várias galerias, fato que the conferiu o nome relacionado a um labirinto. Apresenta duas entradas principais. Próximo às entradas, as galerias apresentam corredores amplos, permitindo boa troca de energia no ambiente. No final da gruta os corredores se estreitam e tornam-se mais tortuosos. Um pequeno curso d'água corre em seu interior.

Três termohigrômetros foram instalados nesta caverna, sendo um na entrada lateral, outro no meio do salão mais interior (salão visitável) e o último no acesso à galeria superior que está fechada para visitação. Os 
equipamentos podem ser visualizados na imagem a seguir (figura 5.9.1). A ausência de um mapa da cavidade impediu a localização dos termohigrômetros. O período de monitoramento foi de 21 a 28 de fevereiro de 2009.
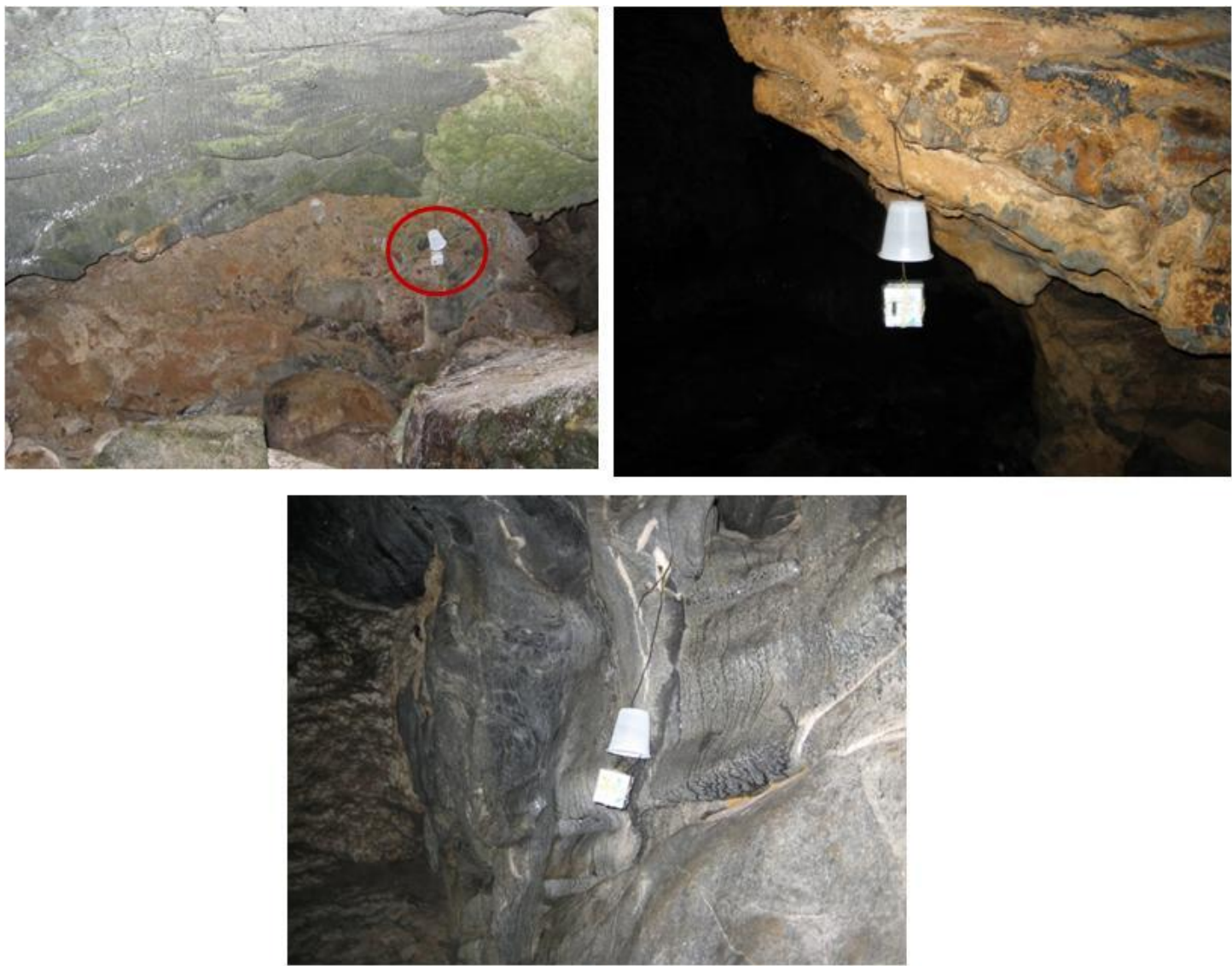

Figura 5.9.1: Foto dos termohigrômetros instalados na Gruta do Minotauro.

Organização e fotografias: Bárbara N. Rocha, 2010.

Os dados obtidos foram trabalhados estatisticamente e podem ser visualizados na tabela a seguir. 
Tabela 5.9.1: Parâmetros estatísticos da temperatura e umidade relativa do ar da Gruta do Minotauro (período de 21 a 28/02/2009).

\begin{tabular}{|l|ccc|ccc|}
\cline { 2 - 7 } \multicolumn{1}{c|}{} & \multicolumn{3}{c|}{ Temperatura do ar $\left({ }^{\circ} \mathrm{C}\right)$} & \multicolumn{3}{c|}{ Umidade relativa do ar (\%) } \\
\cline { 2 - 7 } \multicolumn{1}{c|}{} & Entrada & $\begin{array}{c}\text { Salão } \\
\text { Visitável }\end{array}$ & $\begin{array}{c}\text { Salão não } \\
\text { Visitável }\end{array}$ & Entrada & $\begin{array}{c}\text { Salão } \\
\text { Visitável }\end{array}$ & $\begin{array}{c}\text { Salão não } \\
\text { Visitável }\end{array}$ \\
\hline Média & 16,1 & 17,3 & 17,5 & 100,0 & 90,8 & 100,0 \\
Máximo & 17,8 & 17,5 & 17,8 & 100,0 & 100,0 & 100,0 \\
Mínimo & 14,6 & 17,2 & 17,3 & 100,0 & 62,9 & 100,0 \\
Ammlitude & 3,2 & 0,3 & 0,5 & 0,0 & 37,1 & 0,0 \\
Moda & 15,2 & 17,3 & 17,5 & 100,0 & 100,0 & 100,0 \\
Variância & 0,5 & 0,0 & 0,0 & 0,0 & 163,6 & 0,0 \\
Desvio padrão & 0,7 & 0,1 & 0,1 & 0,0 & 12,8 & 0,0 \\
\hline
\end{tabular}

Organização: Bárbara N. Rocha, 2010.

A entrada da caverna apresentou a menor média térmica do período $\left(16,1^{\circ} \mathrm{C}\right)$. No salão visitável, localizado na parte mais interna da cavidade, a média foi de $17,3^{\circ} \mathrm{C}$ e na área não visitável (acesso à galeria superior) a média foi de $17,5^{\circ} \mathrm{C}$.

Ao contrário do que acontece com a maioria das cavernas, o máximo não foi registrado na entrada e sim em seu salão mais interior. Apesar de sujeita à incidência de radiação solar difusa, a entrada lateral da Gruta do Minotauro apresenta vegetação bastante desenvolvida e uma parede rochosa na lateral que permite a canalização do vento para o interior da cavidade. Por isso, a entrada da gruta é bastante sombreada e permite a subsidência de ar frio, mais denso, em noites de inversão térmica. 0 máximo registrado na entrada foi de $17,76^{\circ} \mathrm{C}$, ante $17,81^{\circ} \mathrm{C}$ no interior.

A mínima temperatura ocorreu na entrada, influenciada pela configuração física desse ponto, sendo de $14,6^{\circ} \mathrm{C}$. Assim, a maior amplitude também se deu nesse ponto, de $3,2^{\circ} \mathrm{C}$. No interior da gruta, as mínimas foram superiores a $17^{\circ} \mathrm{C}$ e amplitudes iguais inferiores a $0,5^{\circ} \mathrm{C}$.

Quanto às modas, nos pontos localizados no interior da caverna esse parâmetro foi muito próximo da média. Esta informação, associada aos baixos valores de variância e desvio padrão, permite concluir que há uma estabilidade térmica nesses locais. Na entrada, a moda foi mais variável e a variância e desvio padrão maiores.

A umidade relativa do ar foi igual a $100 \%$ durante todo o período na entrada da gruta e no acesso à galeria superior. Assim, as médias, 
máximos, mínimos e modas desses pontos foram de $100 \%$ e as amplitudes, variâncias e desvios padrões foram iguais a zero.

No salão visitável, a UR apresentou variações. A média higrométrica do período foi de 90,8\%, com máximo em 100\% e mínimo em 62,9\%, resultando em amplitude de $37,1 \%$. Essa elevada amplitude resultou em variância de 163,6 e desvio padrão de 12,8. Apesar disso, a moda deste ponto foi igual a $100 \%$, indicando que na maior parte do tempo o ar esteve saturado.

A figura 5.9.2 mostra a variação da temperatura do ar no interior da gruta (eixo da direita) e no meio externo (dados da estação meteorológica e da entrada da gruta - eixo da esquerda).

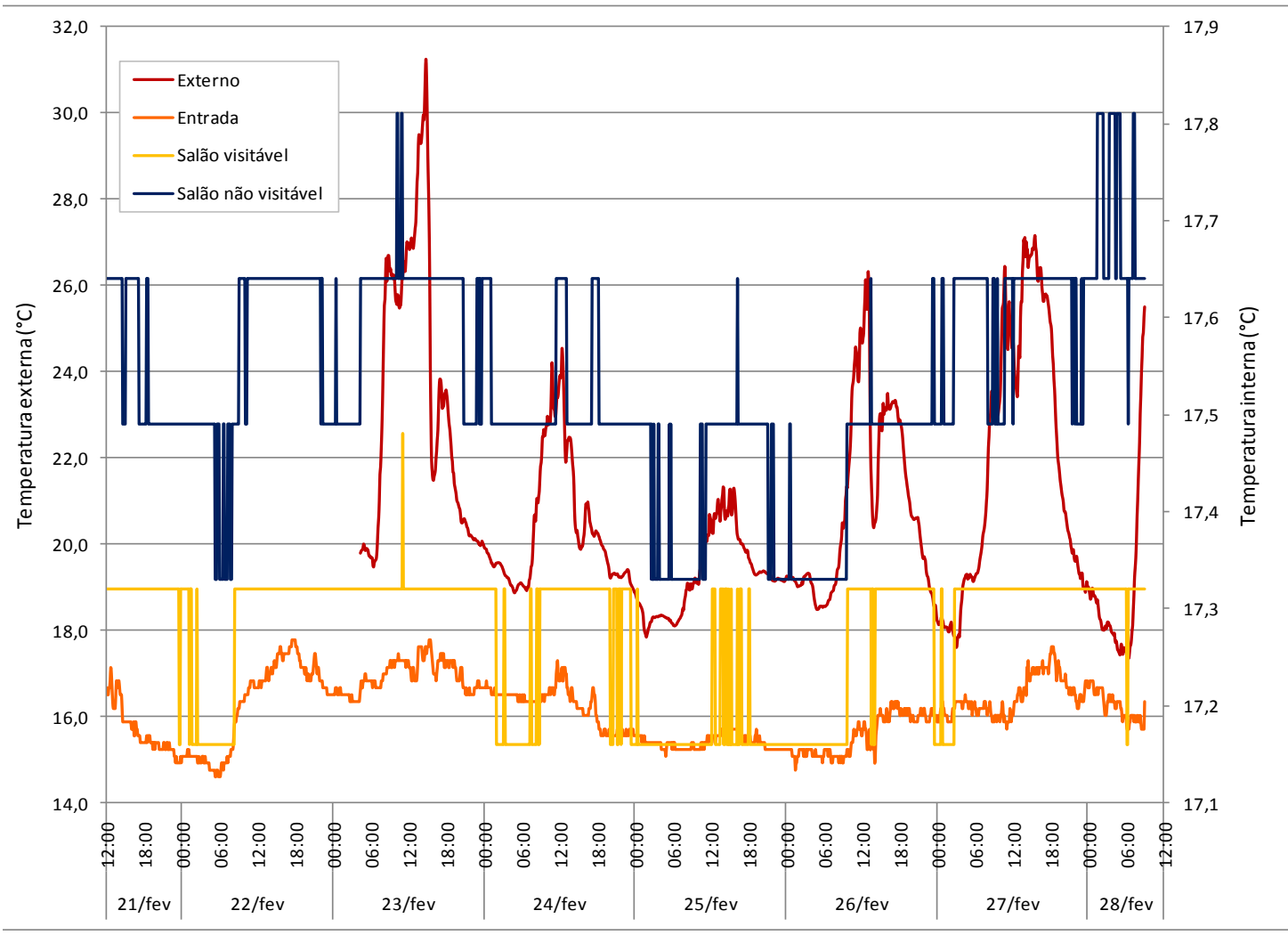

Figura 5.9.2: Variação da temperatura do ar $\left({ }^{\circ} \mathrm{C}\right)$ na Gruta do Minotauro. Organização: Bárbara N. Rocha, 2010.

$\mathrm{Na}$ entrada da caverna, que caracteriza o microclima transicional, a temperatura varia ao longo do dia, apresentando os mínimos no fim da madrugada e máximos pouco depois do meio-dia. A temperatura acompanha as variações do meio externo, com amplitudes térmicas 
reduzidas. Porém, algumas variações do exterior não podem ser percebidas na entrada da caverna.

No salão não visitável, percebe-se uma pequena variação acompanhando levemente a tendência de variação do meio externo. No salão visitável, no fim da galeria, as variações são ainda menores e a assimilação das mudanças do tempo exterior não podem mais ser percebidas.

Três grupos de turistas visitaram esta caverna. Um no dia 22 de fevereiro, composto por duas pessoas, e dois no dia 23, sendo um com cinco e outro com quatro integrantes. A figura 5.9.3 mostra a variação horária da temperatura do ar nestes dois dias.

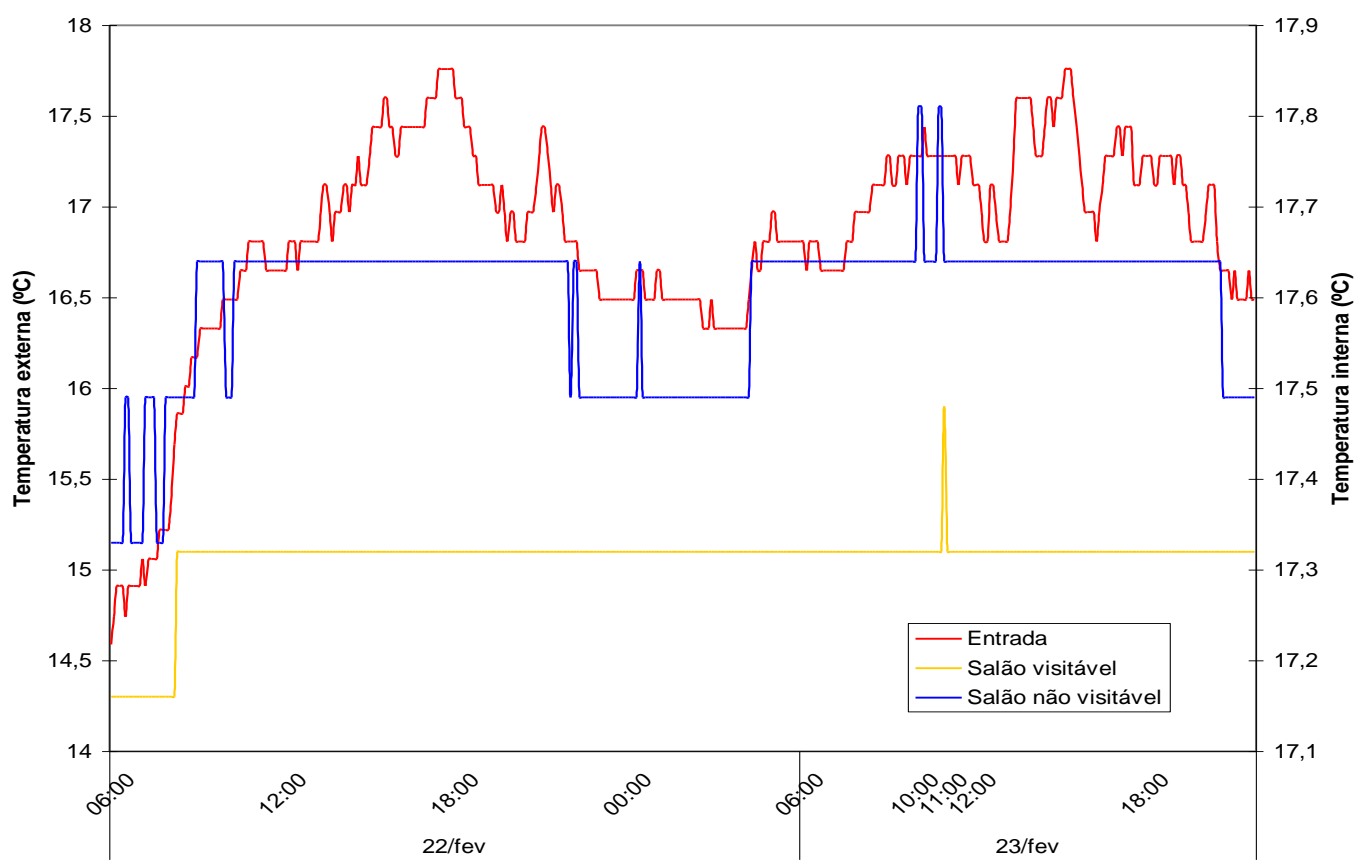

Figura 5.9.3: Variação da temperatura do ar nos dias 22 e 23 de fevereiro.

Organização: Bárbara N. Rocha.

No dia 22, nenhuma alteração na temperatura do ar pôde ser percebida na presença de dois turistas. Já no dia 23, a entrada de nove pessoas na gruta das $10 \mathrm{~h} 00 \mathrm{~min}$ às $11 \mathrm{~h} 20 \mathrm{~min}$ resultou em alterações de $0,2^{\circ} \mathrm{C}$ nos dois salões analisados. A caverna demorou menos de dez minutos pra retornar a situação de estabilidade. Essa alteração não deve 
resultar em grandes impactos para a gruta, visto que está dentro do erro instrumental e que maiores alterações ocorreram em situação natural.

O próximo gráfico (figura 5.9.4) ilustra a variação da umidade relativa do ar na gruta do Minotauro.

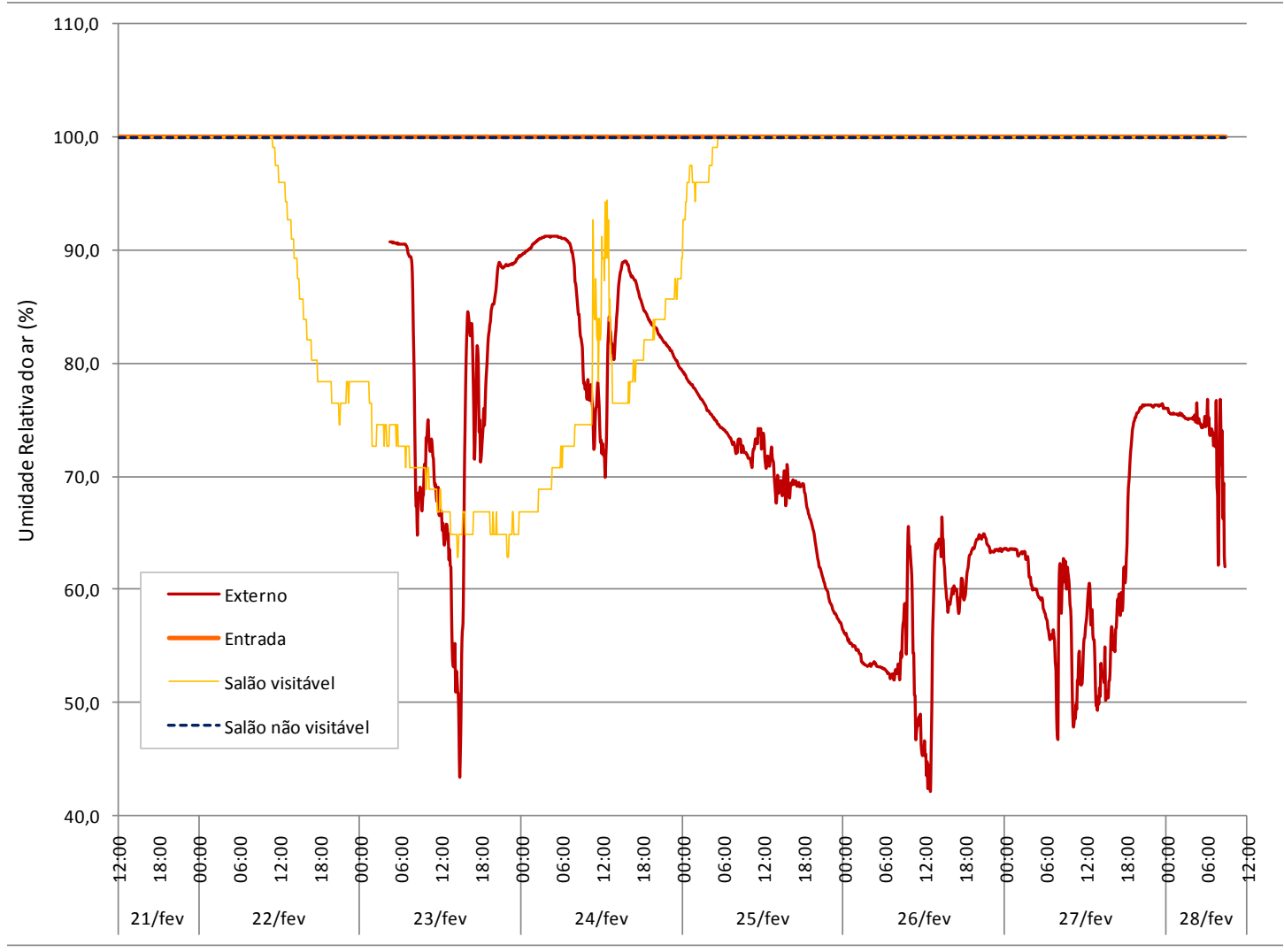

Figura 5.9.4: Variação da umidade relativa do ar (\%) na Gruta do Minotauro.

Organização: Bárbara N. Rocha, 2010.

$\mathrm{Na}$ entrada da caverna e no acesso à galeria superior, o ar esteve saturado durante todo o período, não acompanhando as variações do meio externo. A densa vegetação da entrada e a presença de um curso d'água próximo à área não visitável conferem maior umidade a esses locais.

As únicas variações se deram no salão não visitável, localizado no salão final. A UR começou a cair às 11 h00min do dia 22. Neste dia, duas pessoas visitaram a gruta às $10 \mathrm{~h} 20 \mathrm{~min}$, saindo da caverna às $11 \mathrm{~h} 00 \mathrm{~min}$. No dia 23, nove turistas estiveram na caverna das $10 \mathrm{~h} 00 \mathrm{~min}$ às $11 \mathrm{~h} 20 \mathrm{~min}$. Neste momento, a umidade relativa do ar apresentou uma elevação, voltando a cair após a saída dos visitantes. Essa variação não acompanha o 
ciclo diuturno e pode ser decorrente da visitação turística. Para comprovar esse impacto seriam necessários novos estudos.

A figura 5.9.5 apresenta o perfil de gás carbônico da Gruta do Minotauro, realizado às $9 \mathrm{~h} 00 \mathrm{~min}$ do dia 28/02, na presença de três turistas.

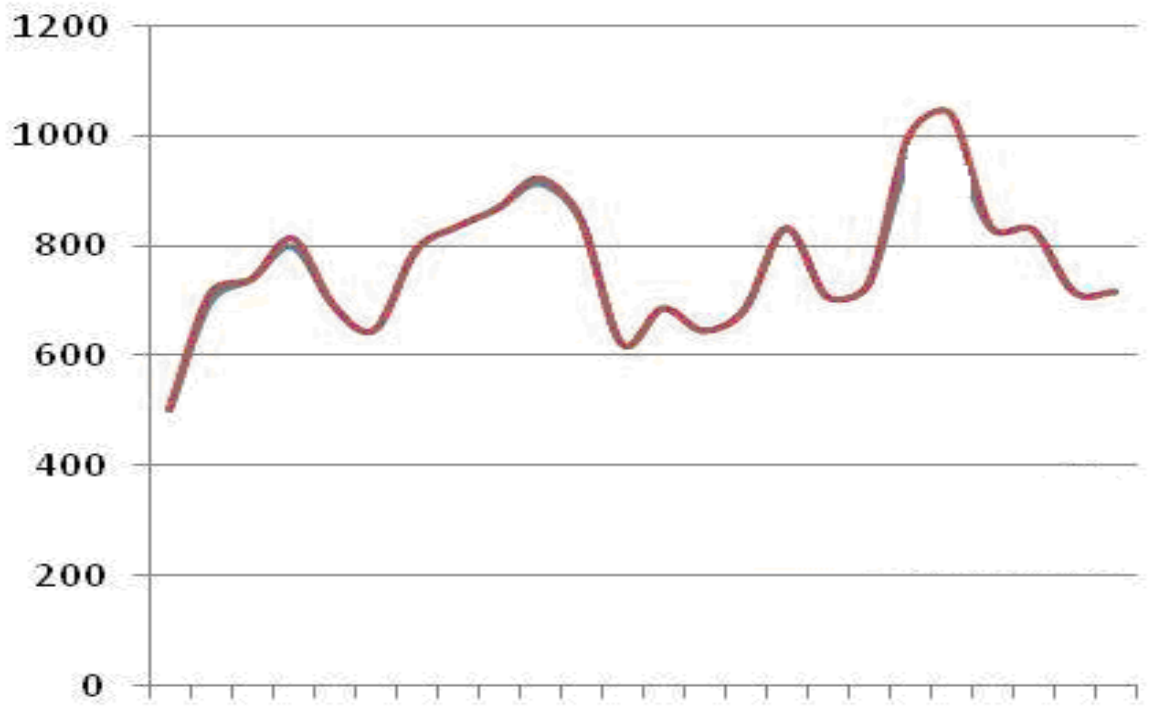

Figura 5.9.5: Perfil de gás carbônico da Gruta do Minotauro.

Organização: Bárbara N. Rocha, 2010.

A concentração de gás carbônico da caverna é bastante variável. Em geral, salões amplos apresentam menores taxas do gás, enquanto nas passagens estreitas as taxas se elevam. O mínimo valor registrado ocorreu na entrada, sendo de 502 ppm e o máximo, de 973 ppm, foi registrado na passagem para o último salão.

Empiricamente, percebeu-se que os salões mais estreitos são pouco ventilados, podendo haver aumento nas taxas de $\mathrm{CO}_{2}$ na presença de turistas. O acesso a essa caverna se faz por uma trilha longa, que deixa os turistas mais exaustos, lançando maiores quantidades de gás carbônico para a atmosfera dessa caverna.

A partir do exposto, pode-se concluir que a presença de turistas na Gruta do Minotauro resultou em variações na atmosfera dessa caverna, nos três atributos analisados (temperatura e umidade relativa do ar e taxa de gás carbônico). O formato labiríntico da gruta dificulta as trocas gasosas entre seus salões e o meio externo. Em futuros estudos, recomenda-se que 
esta caverna seja estudada por um maior período de tempo para melhor compreensão da magnitude desses impactos.

\subsection{0 - Síntese dos resultados}

O objetivo do monitoramento microclimático foi verificar a existência ou não de amplificação de parâmetros atmosféricos frente ao fluxo de visitantes e as condições climáticas no entorno do agrupamento das cavernas.

A tabela 5.10 .1 sintetiza os aspectos físicos das grutas que influenciam em seu microclima.

Tabela 5.10.1: Aspectos físicos das cavidades que influenciam em seu microlcima.

\begin{tabular}{|c|c|c|c|c|c|c|c|c|c|c|}
\hline & \multicolumn{10}{|c|}{ Aspectos físicos } \\
\hline & \multicolumn{2}{|c|}{ Salões } & \multicolumn{2}{|c|}{$\begin{array}{c}\text { Presença de } \\
\text { rio }\end{array}$} & \multicolumn{2}{|c|}{$\begin{array}{c}\text { Presença de } \\
\text { claraboias }\end{array}$} & \multicolumn{2}{|c|}{ Extensão } & \multicolumn{2}{|c|}{ Boca } \\
\hline Caverna & $\frac{\text { on }}{\frac{a}{\varepsilon}}$ & 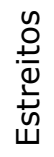 & $\frac{E}{n}$ & $\stackrel{2 \pi}{2}$ & $\frac{E}{n}$ & $\stackrel{\circ}{2 \pi}$ & $\begin{array}{l}\frac{0}{C} \\
\frac{0}{d} \\
\frac{\sigma}{d} \\
\alpha\end{array}$ & 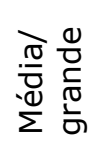 & 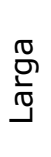 & 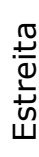 \\
\hline Detrás & & $x$ & & $x$ & $x$ & & $x$ & & & $x$ \\
\hline Fogo & $x$ & & $x$ & & & $x$ & & $x$ & $x$ & \\
\hline Tatu & $x$ & & $x$ & & $x$ & & $x$ & & $x$ & \\
\hline Meninos & & $x$ & & $x$ & $x$ & & $x$ & & & $x$ \\
\hline $\begin{array}{c}\text { Jane } \\
\text { Mansfield }\end{array}$ & $x$ & & $x$ & & & $x$ & & $x$ & & $x$ \\
\hline Fendão & $x$ & & $x$ & & $x$ & & & $x$ & $x$ & \\
\hline Mãozinha & $x$ & & & $x$ & & $x$ & $x$ & & $x$ & \\
\hline Santa & $x$ & & $x$ & & & $x$ & $x$ & & $x$ & \\
\hline Minotauro & $x$ & & $x$ & & & $x$ & & $x$ & $x$ & \\
\hline
\end{tabular}

Organização: Bárbara N. Rocha, 2010. 
Foram considerados como amplos os salões ou corredores em que pelo menos duas pessoas de estatura e peso medianos possam caminhar lado a lado. Na gruta dos Meninos e do Cipó, todos os corredores são estreitos.

A maioria das cavernas estudadas apresenta cursos d'água em seu interior. Quando os rios são caudalosos, como ocorre na Gruta do Fendão e na Jane Mansfield, e a caverna apresenta claraboias, a circulação do ar é facilitada, fato que pôde ser comprovado empiricamente.

Nas cavernas com bocas estreitas, onde é necessário se agachar para adentrá-las, a influência das variações climáticas externas tende a ser menor; enquanto nas grutas de pequena extensão (desenvolvimento inferior a $100 \mathrm{~m}$ ) espera-se uma maior variação nos atributos do clima.

O microclima da Gruta Detrás acompanha, com menores amplitudes, as variações do meio externo. Isso se deve à sua pequena extensão e à presença de claraboias. No entanto, esta caverna apresentou impactos de baixa magnitude (variações inferiores às que ocorrem normalmente ao longo de um dia) em sua temperatura decorrentes da visitação por um pequeno grupo de turistas.

$\mathrm{Na}$ gruta do Fogo, elevações da temperatura do ar e nas concentrações de dióxido de carbono foram detectadas na presença de turistas, nos dois salões estudados. Esta caverna não apresenta claraboias, fato que, aliado à sua média extensão, impedem que a atmosfera de seu interior "enxergue" as variações do meio externo.

A Toca dos Meninos apresenta pequena extensão. Por isso, até o meio da galeria, o clima desta gruta acompanha as variações do meio externo. No salão final, mais confinado, a temperatura tende a estabilidade.

A atmosfera da gruta do Tatu acompanha as variações do meio externo. Sua conformação, com entrada e corredores amplos, extensão pequena e presença de rio e claraboias, elevam a capacidade de trocas gasosas com o meio exterior.

A Gruta do Fendão também apresenta elevada capacidade de troca energética com o meio externo, devido a seus amplos salões com claraboias e rio caudaloso. 
As variações de temperatura e umidade relativa do ar na gruta Jane Mansfield são devido às altas trocas energéticas proporcionadas pelo rio corrente. Essa caverna não apresentou alterações em sua atmosfera em períodos com visitação turística.

Em condições normais de visitação (sem uso de carbureteira), não foram mensuradas alterações nos parâmetros atmosféricos da Gruta da Mãozinha em períodos com visitação. Sua pequena extensão e boca ampla propiciam maior troca energética com o meio externo.

A gruta da Santa apresenta estabilidade nos atributos microclimáticos medidos. Apenas nas áreas próximas à entrada da gruta as variações climáticas externas podem ser percebidas.

A Gruta do Minotauro apresenta corredores estreitos e formato labiríntico, dificultando as trocas de energia com o meio externo. Por isso, ela apresentou alterações em todos os parâmetros climáticos analisados quando da visitação turística. A temperatura elevou-se nos dois salões, a umidade relativa apresentou queda no salão visitável e os níveis de $\mathrm{CO}_{2}$ foram variáveis em quase todo perfil. 


\section{Conclusões e considerações finais}

Este trabalho mostrou-se de fundamental importância para compreensão do microclima do ambiente de cavernas. Em geral, elas apresentam elevada umidade relativa do ar, atingindo a saturação, e temperatura tendendo a estabilidade na medida em que se adentra nas grutas. A concentração de gás carbônico é maior no interior das cavidades, comparado ao meio externo.

Correlacionando os dados obtidos com a conformação das cavernas, pode-se concluir que grutas com grandes entradas e claraboias apresentam um microclima ainda regido pela dinâmica do ambiente externo. Cavernas com menores aberturas não "enxergam" a atmosfera externa.

A presença de rios de águas caudalosas e claraboias mostraram-se os fatores mais determinantes para variação do microclima no interior de cavernas do que a extensão da gruta, a amplitude dos salões e a largura da boca.

Todas as grutas com rio de água corrente apresentaram microclima variável (não estável). Conclui-se, por isso, que a água é um mecanismo importante de circulação em ambientes cavernícolas.

As grutas que têm claraboias também apresentaram microclima variável, pois há, nessas cavernas, trocas gasosas com o meio externo.

Variações no microclima das grutas estudadas em decorrência da visitação turística ocorreram, em geral, em cavernas secas, com corredores e entradas estreitos e sem claraboias. Essas características dificultam a circulação do ar e consequente troca energética entre os meios externo e interno. As grutas que apresentaram impactos foram a do Minotauro, Detrás, do Fogo, dos Meninos e da Mãozinha (esta última em decorrência do uso de carbureteiras).

Em grutas de pequena extensão, acreditava-se que as trocas gasosas com o ambiente externo seriam facilitadas, impedindo a estabilização dos parâmetros microclimáticos medidos, especialmente a temperatura do ar. No entanto, as cavernas de menores dimensões foram as que apresentaram 
impactos decorrentes do turismo, mostrando que a extensão da caverna não é um fator importante para circulação do ar no interior das grutas.

A circulação do ar é facilitada em grutas com rios de águas caudalosas, salões amplos, entradas e corredores largos e presença de claraboias. Isso gera maiores variações nos atributos do microclima, dificultando a geração de impactos no ambiente em decorrência do turismo.

Ficou demonstrado também, a partir de testes realizados na gruta da Mãozinha, que o uso de carbureteiras altera significativamente as concentrações de gás carbônico na atmosfera cavernícola. Um único aparelho ligado foi suficiente para aumentar em 2,5 vezes as taxas de $\mathrm{CO}_{2}$ nessa caverna.

Vale lembrar que a metodologia para este estudo não permite compreender as alterações sazonais naturais do clima do ambiente de cavernas. Assim, em alguns casos, não é possível afirmar conclusivamente se as alterações encontradas são decorrentes da presença antrópica ou de fatores naturais.

Ressalta-se, também, que os testes de visitação foram feitos com pequenos grupos de visitantes. Assim, não se podem ampliar as conclusões sobre os impactos para grupos médios e grandes, que trazem um maior aporte de energia para o interior das cavidades.

Os resultados desse trabalho permitem aceitar, em partes, as hipóteses formuladas.

1) O microclima de cavernas, em situação natural, apresenta atrasos na assimilação das condições atmosféricas externas, além de reduzida amplitude térmica. Porém, em algumas cavernas, especialmente naquelas que apresentam rios de água corrente, a temperatura do ar pode variar nas zonas afóticas, mas com menores amplitudes que no meio externo.

2) A visitação turística, pelo uso de iluminação artificial e pelo calor do corpo humano, pode alterar a temperatura do ar em algumas cavernas. No entanto, as mudanças na temperatura não resultam em variações na umidade relativa do ar.

3) O turismo em caverna com uso de carbureteira eleva, de fato, a concentração de gás carbônico em sua atmosfera. 
Por fim, acredita-se que este trabalho possa contribuir para melhor entendimento deste ambiente único e carente de estudos que são as cavernas. Ressalta-se, no entanto, que esta pesquisa não esgota o tema. Muito ainda há de ser estudado para que possamos compreender o ritmo do microclima cavernícola. O intervalo de tempo adotado para registrar os atributos do clima nesta pesquisa (uma semana) não permite compreender a sazonalidade climática das grutas. Estudos com análises em maior período de tempo são sugeridos para futuras pesquisas. Outros trabalhos também podem buscar identificar a capacidade de suporte das grutas, considerando seus aspectos microclimáticos. 


\section{Bibliografia}

ALEY, T. De volta à primeira casa: o mundo subterrâneo das cavernas In: Ciência e Futuro 1997. São Paulo: Ed. Melhoramentos, 1997.

ARMANI, G., TAVARES, R. e ROCHA, B. N. Caracterização pluvial da Baixada Santista como subsídio à prevenção de desastres naturais. Anais do XI Simpósio Brasileiro de Geografia Física Aplicada. São Paulo, 2005.

ARMANI, G., TAVARES, R. e ROCHA, B. N. A influência das brisas marítima e terrestre na gênese das chuvas no transecto Cubatão-São Paulo (SP). Anais do XIV Congresso Brasileiro de Meteorologia. Florianópolis, 2006.

BRASIL. Decreto no 750. 1993.

BRASIL. Política Nacional do Meio Ambiente. Lei no 6983 (1981).

BRASIL. Resolução CONAMA nº 001. 1986.

BRASIL. Resolução CONAMA no 347. 2004

CARVALHO, S. M. Estudo de microclima subterrâneo: o exemplo da Gruta Olhos D'água - Castro (PR). In: ZAVATTINI, J. A. Estudos do clima no Brasil. São Paulo: Alínea editora, 2004. p. 212-213.

CONTI, J. B. Circulação secundária e efeito orográfico na gênese das chuvas na região lesnordeste paulista. São Paulo, 1v. Tese (Doutorado) - Faculdade de Filosofia, Letras e Ciências Humanas, Universidade de São Paulo. São Paulo, 1975. 82p.

GEIGER, R. Manual de microclimatologia: o clima da camada de ar junto do solo. 4. ed. Lisboa: Fundação Calouste Gulbenkian, 1961. 556p.

GILLIESON, D. Caves: processes, development, management. Blackwell, 1996. 324p.

GUTJAHR, M. R. Critérios relacionados a compartimentação climática de bacias hidrográficas: a Bacia do Rio Ribeira de Iguape. São Paulo, 1v. Dissertação (Mestrado) - Faculdade de Filosofia, Letras e Ciências Humanas, Universidade de São Paulo. São Paulo, 1993. 
KARMANN, Ivo. Ciclo da água: água subterrânea e sua ação geológica. In: TEIXEIRA, W., Decifrando a Terra. Oficina de textos: São Paulo, 2003.

LIÑAN, C., VADILLO, I e CARRASCO, F. La concentración de CO2 del aire em la Cueva de Nerja (Málaga, España). Hidrogeologia y Aguas Subterrâneas, 18, 2006. P. 357-364.

LINO, C. F. Cavernas: o fascinante Brasil subterrâneo. São Paulo: Gaia, 2001.

LINO, C. F. e ALLIEVI, J. Cavernas Brasileiras. São Paulo: Edições Melhoramentos, 1980. 168p.

LONGHITANO, G. A., ROCHA, B. N. e ÂNGELO FURLAN, S. Caracterização microclimática da Gruta Colorida - Parque Estadual de Intervales, SP. In: Anais do VII Simpósio Brasileiro de Climatologia Geográfica. Rondonópolis, 2006.

MILANESI, M. A. A ilha de São Sebastião no Estado de São Paulo: estudos pluviométricos. Anais do VI Simpósio Brasileiro de Climatologia Geográfica. Aracaju, 2004.

MONTEIRO, C. A. de F. A dinâmica climática e as chuvas no Estado de São Paulo. Atlas. São Paulo, Instituto de Geografia/USP, 1973. 129p.

MONTEIRO, C. A. de F. Teoria e clima urbano. São Paulo, 1v. Tese (Livre docência) - Faculdade de Filosofia, Letras e Ciências Humanas, Universidade de São Paulo. São Paulo, 1975.

PALOMBA, V. Proposta per la fruzione naturalística di um ambiente ipogeo neo parco fluviale del revere. Universitá Degli Studi di Perugia Facolta' di Scienze, 1995.

PELEGATI, C. H. G. O efeito orográfico no perfil Mogi-Bertioga. Anais do XI Simpósio Brasileiro de Geografia Física Aplicada. São Paulo, 2005.

ROCHA, B. N., LONGHITANO, G. A. e ÂNGELO FURLAN, S. Levantamento climáticofaunístico da Gruta Colorida do Parque Estadual de Intervales. In: Anais do IV Congresso Brasileiro de Biometeorologia. Ribeirão Preto, 2006.

RODRIGUES, C. A teoria geossistêmica e sua contribuição aos estudos geográficos e ambientais. Revista do Departamento de Geografia, São 
Paulo, n. 14, p. 69-77, 2001.

ROSS, J. L. S. A morfogênese da bacia do Rio Ribeira do Iguape e os sistemas ambientais. Revista GEOUSP - Espaço e Tempo, São Paulo, n. 12 , p. $21-26,2002$.

ROSS, J. L. S. e MOROZ, I. C. Mapa geomorfológico do Estado de São Paulo. Escala 1:500000. São Paulo: Instituto de Pesquisas Tecnológicas, v. I/II, 1997.

SÁNCHEZ, L. E. Avaliação de impacto ambiental: conceitos e métodos. São Paulo: Oficina de Textos, 2008. 495p.

SÁNCHEZ-MARTOS, F., CALAFORRA, J. M., FERNÁNDEZ-CORTES, A. e GONZÁLES-RÍOS, M. J. Experiência de visitas masivas a cavidades em condiciones naturales: la Cueva del Água de Iznalloz (Granada). Geogaceta, 31, 2002. P. 23-26.

SANO, N. N. Estudo comparado da gestão das visitações nos Parques Estaduais Turísticos do Alto Ribeira (PETAR) e Intervales (PEI). Dissertação (mestrado). São Paulo: USP, 2007. 100p. (+ anexos).

SANT'ANNA NETO, J. L. As chuvas no Estado de São Paulo: contribuição ao estudo da variabilidade e tendência da pluviosidade na perspectiva da análise geográfica. São Paulo, 1v. Tese (Doutorado) - Faculdade de Filosofia, Letras e Ciências Humanas, Universidade de São Paulo. São Paulo, 1995. 201p.

SANT'ANNA NETO, J. L. Ritmo climático e a gênese das chuvas na zona costeira paulista. São Paulo, 1v. Dissertação (Mestrado) Faculdade de Filosofia, Letras e Ciências Humanas, Universidade de São Paulo. São Paulo, 1990.

SÃO PAULO (Estado). Parque Estadual Intervales: plano de gestão ambiental - fase 1. 1994.

SÃO PAULO (Estado). Parque Estadual Intervales: plano de manejo. 2009.

SCALEANTE, J. A. B. Avaliação do impacto de atividades turísticas em cavernas. Dissertação (mestrado). Campinas: UNICAMP, 2003. 70p. (+ anexos). 
SOTCHAWA, V. B. O estudo dos geossistemas. In: Revista IG-USP (Cadernos Métodos em Questão), n.16. São Paulo, 1977.

VERÍSSIMO, C. U., SOUSA, A. E. B. A. de, RICARDO, J. M., BARCELOS, A. C., NOGUEIRA NETO, J. de A., REIS, M. G. M. Microclima e espeleoturismo na gruta de Ubajara, CE. In.: Anais... $27^{\circ}$ Congresso Brasileiro de Espeleologia. Januária, 2003.

VIANA JUNIOR, O. Hidroquímica, hidrologia e geoquímica isotópica (O e H) da fácie de percolação vadosa autogênica, Caverna Santana, município de Iporanga, Estado de São Paulo. Dissertação (mestrado). São Paulo: Instituto de Geociências/ USP, 2002. 113p.

\section{1 - Sites consultados}

Departamento de Química da USP. Disponível em: http://www.cdcc.usp.br/quimica/ciencia/cavernas.html. Acesso em 16 de outubro de 2009.

Departamento de Geografia da FFLCH/ USP. Disponível em: http://www.geografia.fflch.usp.br/mapas/Atlas_Intervales/. Acesso em 15 de outubro de 2009.

Revista ECOTUR. Disponível em:

http://www.revistaecotour.com.br/novo/home/default.asp?tipo=noticia\&id= 1247. Acesso 28/10/2009. 
8.1 - Questionário de visitação em cavernas

Caverna:

\begin{tabular}{|l|c|c|c|c|}
\hline Data & $\begin{array}{c}\text { Horário de } \\
\text { entrada }\end{array}$ & $\begin{array}{c}\text { Horário de } \\
\text { saída }\end{array}$ & $\begin{array}{c}\text { Número de } \\
\text { visitantes }\end{array}$ & $\begin{array}{c}\text { Fontes de } \\
\text { iluminação }\end{array}$ \\
\hline & & & & \\
\hline & & & & \\
\hline & & & & \\
\hline & & & & \\
\hline & & & & \\
\hline & & & & \\
\hline & & & & \\
\hline
\end{tabular}

